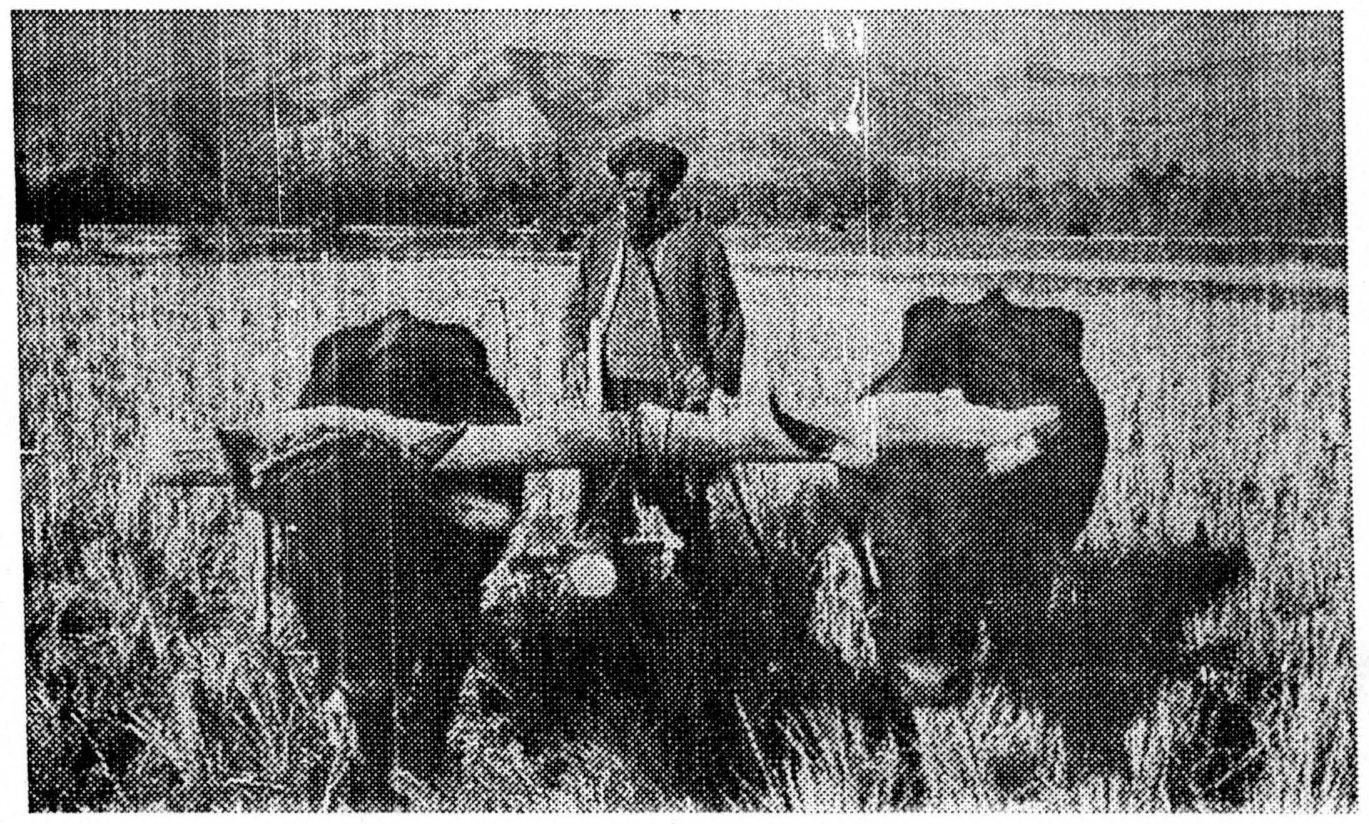

\title{
A BASELINE SURVEY REPORT
}

Chaghcharan, Teywara and Saghar Districts, Ghor Province

A joint survey commissioned by: Afghar aid, Christian Aid, Coordination of Humanitarian Assistance and International Assistance Mission

\section{Afghanaid}

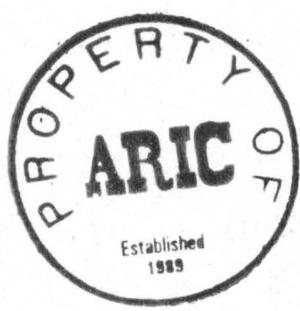

Monitoring and Research Unit

December 1998 


\section{TABLE OF CONTENT}

Table of content

i-iv

Executive Summary

$\mathrm{v-vi}$

PART I. Introduction and General Methodology

1.1. Introduction

1.2. Survey Methodology

1.2.1. Preparatory Work 3

1.2.2. Data Collection Method 3

1.2.3. Questionnaires 6

1.2.4. Sampling 7

$\begin{array}{ll}\text { 1.2.5. The Survey Team } & 12\end{array}$

$\begin{array}{ll}\text { 1.2.6. Data Analysis and Report writing } & 12\end{array}$

PART II. GHOR PROVINCE AND THE CASE DISTRICTS

2.1. Ghor Province 14

2.1.1. Population and History 14

2.12. Major Livelihood 14

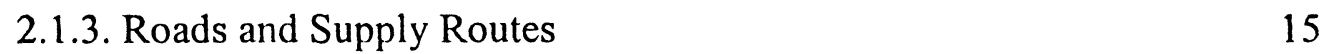

$\begin{array}{ll}\text { 2.1.4. Security and Political Balance } & 17\end{array}$

2.1.5. Materials and Inputs 19

2.1.6. Public Institutions 19

2.1.7. Mine 19

2.1.8. Aid Work 20

2.2. The Case Districts 20

$\begin{array}{ll}\text { 2.2.1. Land and Population } & 23\end{array}$

2.2.2. Agriculture 25

2.2.3. Agrarian System 26

2.2.4. Crop Enterprise 26 
2.2.6. Irrigation 29

2.2.7. Flood Protection $\quad 30$

2.2.8. Marketing Infrastructure 31

2.2.9. Location and its Impacts 32

2.2.10. Off-farm Employment $\quad 34$

2.2.11. Health Infrastructure 35

2.2.12. Education 36

2.2.13. Veterinary Services 37

2.2.14. The Position of Women 37

PART III. HOUSEHOLD CHARACTERISTICS $\mathbf{4 1 - 4 5}$

3.1. Household Size and Structure 41

3.2. Farm Irrigation Status and its Distribution 43

3.3. Land Tenure $\quad 44$

3.4. Land Status and Productivity Compared 45

PART IV. AGRICULTURAL PRODUCTION $\quad \mathbf{4 6 - 7 5}$

4.1. Cropping Pattern 46

4.2. Variation in the Cropping Pattern by Farm Size

4.3. Crop Rotation 48

4.4. Intercropping 49

4.5. The Management of Staples $\quad 50$

4.5.1. Labour Use $\quad 50$

4.5.2. Crop Calendar 53

4.5.3. Seasonality of Labour Demand and Wages 53

4.5.4. Farm Equipment and Farm Power 62

4.5.5. Yield Analysis 62

4.5.6. Fertiliser Application $\quad 65$

4.5.7. Profitability Analysis 66

4.5.8. System Constraints 67

4.5.9. Agronomic Constraints 70 
5.1. Marketing of Agricultural Products 76

5.2. Food Security 77

5.2.1. Direct Food Entitlement 77

5.2.2. Indirect Food Entitlement 79

5.2.3. Copping Strategies 79

5.2.4. Food Purchase $\quad 82$

5.2.5. Causal Labour 84

$\begin{array}{ll}\text { 5.2.7. Credit } & 85\end{array}$

PART VI. HOUSEHOLD INCOME AND EXPENDITURE

6.1. Household Income

6.2. Houschold Expenditure

PART VII. THE LIVESTOCK ECONOMY

7.1. Livestock Population and Herd Composition 93

7.2. Lirestock Productivity 97

7.3. Constraints to Livestock Productivity 98

7.3.1. Animal Feed 98

$\begin{array}{ll}\text { 7.3.2. Animal Diseases } & 10()\end{array}$

PART VIII. HEALTH AND HEALTH PRACTICES

8.1. Common Illuesses and Immunisation $1(12$

$\begin{array}{ll}\text { 8.2. Nutrition of Women } & 103\end{array}$

$\begin{array}{ll}\text { 8.3. Child Feeding } & 104\end{array}$

8.4. Disabilitics 104

8.5. Common Illnesses and Immunisation 105

8.6. (hild Loss and Fertility Analysis 106) 
PART IX. MANAGEMENT OF COMMON PROPERTY RESOURCES

9.1. Forest Resources 


\section{EXECUTIVE SUMMARY}

This summary highlights the main findings of the baseline survey, undertaken jointly by Afghanaid, Christian Aid, Coordination of Humanitarian Assistance and International Assistance Mission in three districts of Ghor province - Chaghcharan, Teywara and Saghar. The survey aimed at assessing people's priority needs and determining the potential for development work. Relevant information was collected by means of RRA, PRA and formal survey, focusing on two levels - community and household. The former provided information aggregated at the district and sectoral levels - the services and infrastructure available to the people and the viability of institutions to manage common property resources Political and security matters are also studied. The household level survey is concerned with the micro-level and provides information on such factors as access to resources/distribution, production, consumption, incomes and expenditure.

The survey clearly indicates that Ghor is by far the poorest province in Afghanistan. The civil conflict has exacerbated its relative isolation, deterioration of the physical infrastructure, agricultural and commercial activities. Too many people live in absolute poverty and deprivation. Child mortality is high as is birth rate, leading to high maternal mortality rate. Life expectancy is low and people die from all kinds of preventable diseases. Technology is rudimentary; agriculture and animal husbandry are very much subsistence-oriented and the vast majority of households are food-deficit for the best part of the year. There are no off-farm income sources locally; young men and boys migrate seasonally to neighbouring provinces and countries looking for employment and remit income to their homes. Women try to supplement income from handicraft works, but demand for their products is low locally and more profitable markets in Herat and elsewhere are inaccessible due to lack of roads. Indigenous institutions are no longer effective in managing common property resources, and poverty is exacerbating environmental deterioration. The "institutional vacuum," created by the collapse of government administration and structure, has not been filled by aid agencies. Unlike in other parts of Afghanistan where aid agencies try to redress development problems, Ghor remains NG() virgin.

Security is not much of a concern in Ghor. Local skirmishes that were common until recently have now receded as Taliban assumed total control of the province. Local leaders have repeatedly expressed their enthusiasm to cooperate. The fact that the majority of the population 
belongs to a single ethnic group - Tajik - offers stability and opportunities to initiate long-term development programmes. Some indigenous support systems are still intact and these provide a focal point for potential development through village organisation. Afghanaid's experience clearly indicates that poverty is best tackled by creating an enabling environment, building local capacity and ensuring the participation of women in the development process. Community development, in this context, is an effective approach to increase productivity, improve livelihood security and welfare. Significant improvements can be made even with a modest intervention aimed at productive infrastructure, support services and local capacity building Institutional developments at the village level for men and women and mobilising local savings are feasible and will go a long way in ameliorating absolute poverty. The report recommends that Afghanaid, Christian Aid, Coordination of Humanitarian Assistance and International Assistance Mission should draw a common strategy in order to deliver "effective aid" and optimise impact. Aid agencies in Afghanistan have reached a stage where they need to take a hard look at where they stand vis-à-vis relief and development. Owing to the location of the province, management, personnel and operational matters also demand a coordinated strategy. 
belongs to a single ethnic group - Tajik - offers stability and opportunities to initiate long-term development programmes. Some indigenous support systems are still intact and these provide a focal point for potential development through village organisation. Afghanaid's experience clearly indicates that poverty is best tackled by creating an enabling environment, building local capacity and ensuring the participation of women in the development process. Community development, in this context, is an effective approach to increase productivity, improve livelihood security and welfare. Significant improvements can be made even with a modest intervention aimed at productive infrastructure, support services and local capacity building. Institutional developments at the village level for men and women and mobilising local savings are feasible and will go a long way in ameliorating absolute poverty. The report recommends that Afghanaid, Christian Aid, Coordination of Humanitarian Assistance and International Assistance Mission should draw a common strategy in order to deliver "effective aid" and optimise impact. Aid agencies in Afghanistan have reached a stage where they need to take a hard look at where they stand vis-à-vis relief and development. Owing to the location of the province, management, personnel and operational matters also demand a coordinated strategy. 


\section{Part I. Introduction and General Methodology}

\section{1. Introduction}

This is a "baseline" survey report undertaken jointly by Afghanaid (AAD), Ecumenical Office/Christian Aid (EO/CA), Co-ordination of Humanitarian Assistance (CHA) and International Assistance Mission (IAM) in Ghor province. The survey was implemented in July 1998 in three districts: Chaghcharan, Teywara and Saghar (Map 1). It ivas conducted prior to the recent war and the consequent shift in the political balance in favour of the Taliban. Despite this new political configuration, all the parameters measured by this survey, both at the household and community level, remain valid.

Since 1997, the situation in Ghor and the potential role of aid agencies has been appraised by different organisations, such as WFP, MSF and IAM. Yet, not much has happened in terms of initiating even rehabilitation activities. In March this year, EO/CA approached AAD to suggest a joint survey of Ghor province together with existing Christian Aid partners IAMI and CHA to prepare the groundwork for a co-ordinated programme in (Ghor. From AAI) point of view, this was deemed productive, because it will enhance inter-agency co-operation, complement each other's skill and expertise and permit interventions on a sectoral basis so that each agency can focus on the sector(s) where its strength lies. This idea was discussed at a higher level by the two organisations in London and in Peshawar. It was then agreed that the survey should be done by all the four agencies and each agency should study in depth one or two sectors, and produce a draft report. AAD had the overall responsibility of leading the survey team, defining the methodology and sampling strategies, designing the questionnaires and checklists and, finally, producing the Ghor baseline report on behalf of the participating agencies.

The objective of this survey is, therefore, to assess the viability of the province for development programmes. The data collected can also be used as a "baseline" in order to compare the impact of programme activities on the community in the future. The selection of sample districts was dictated by sectoral and contiguity issues of the participating agencies. Thus, Chaghcharan was selected because, IAM has been keen to open a provincial office there since 1997. In pursuit of this objective, IAM has already conducted a reconnaissance 
survey. Being the seat of the government and accessible by air, Chaghcharan was preferred over other districts (IAM, 1997).

CHA has recently started to work in Farah province. Being con. guous to Farah, Ghor offered a logical expansion to CHA in its programme activities. Thus, Teywara and Saghar districts were included in the survey.

Afghanaid for its part had already conducted a RRA survey in three districts (Tulak, Shahrak and Chaghcharan) in 1995, and it was about to open a programme in the province when fighting engulfed the region. AAD therefore saw this survey a step closer to realising its longterm interest of working in one of the poorest provinces of Afghanistan.

The report is structured in ten major parts. Part I deals with the introduction, objectives and methodological issues. In Part II, the main features of the districts are presented and relevant comparisons are made. The discussion is directed at the community-level by aggregating the data into location and district-wise. In Part III, farm household level data are prescnted. Having classified households by farm and household size, the basic characteristics of households are presented. The section also deals with the distribution of farm sizes and production relations.

Part IV is about agricultural production. It covers cropping ratterns, management systems and a detailed analysis of harvest yields. Part V deals with marketing, food security and the various coping strategies pursued by farm households. This is followed by the analysis of income and expenditure patterns in Part VI. The livestock sector economy is discussed in Part VII. It shows changes in herd size and composition overtime. The section is also concerned with livestock productivity.

In Part VIII, health services and practices are addressed. Information is given on illness among children, immunisation status, birth and mortality rates. There is also information on basic health issues involving water and sanitation.

Part IX looks into environmental sustainability by examining the management of common property resources. In particular, the section deals with forests and grazing land managcment and the various types of property rights. 
Finally, in Part X, we summarise the key findings of the survey and assess the viability of each district for development programmes. The report concludes with a recommendation.

\subsection{Survey Methodology}

\subsubsection{Preparatory Work}

Preparatory work of the survey involved reviewing survey reports produced by WFP, MSF, IAM and Afghanaid. In addition, maps (FAO, DCA, and UNIDATA) and population data (UNIDATA, Atlas Afghanistan, Central Statistics Office) were studied and some background information was also compiled from the different organisations involved in the survey.

\subsubsection{Data Collection Methods}

The survey methodology is a combination of RRA, PRA and formal questionnaires. administered to community members of both men and women and sample houscholds. Group discussions with men and women, direct observation, use of indicators, ranking, maps, key informants, checklists, schematic tools, such crop calendars and labour-schedule constituted the main research tools. Group discussion is central to the methodology of RRA. Following this tradition, a total of eightecn group meetings -..- one in each village -.. were held. Discussions were conducted in a central place, often outside mosques. Group discussions with women were held inside the residential-compound of one of the women. Many of the male participants were full-time, owner and owner-cum-sharecropper farmers, some were able to read and write (Figures I.1 and I.2). All female participants were skilled, but of different age groups (Figure I.3).

The "community level" survey focused on the village population collectively, their gencral activities and practices, and relationships among them. It was administered to farmers who participated in the group discussions and community-wide information was collected on such subjects as infrastructure, agriculture, services and natural resource management. The women were asked about gender-specific questions pertaining to the division of labour, income gencration and health practices. By applying the methodology of $P R \wedge$. male participants were asked to draw village maps and, using this as a starting point, management practices of forests and pastures were studied. The maps were re-drawn in computers using "free-hand" 
Figure I.1. Occupational Pattern of Focus Group Paticipants

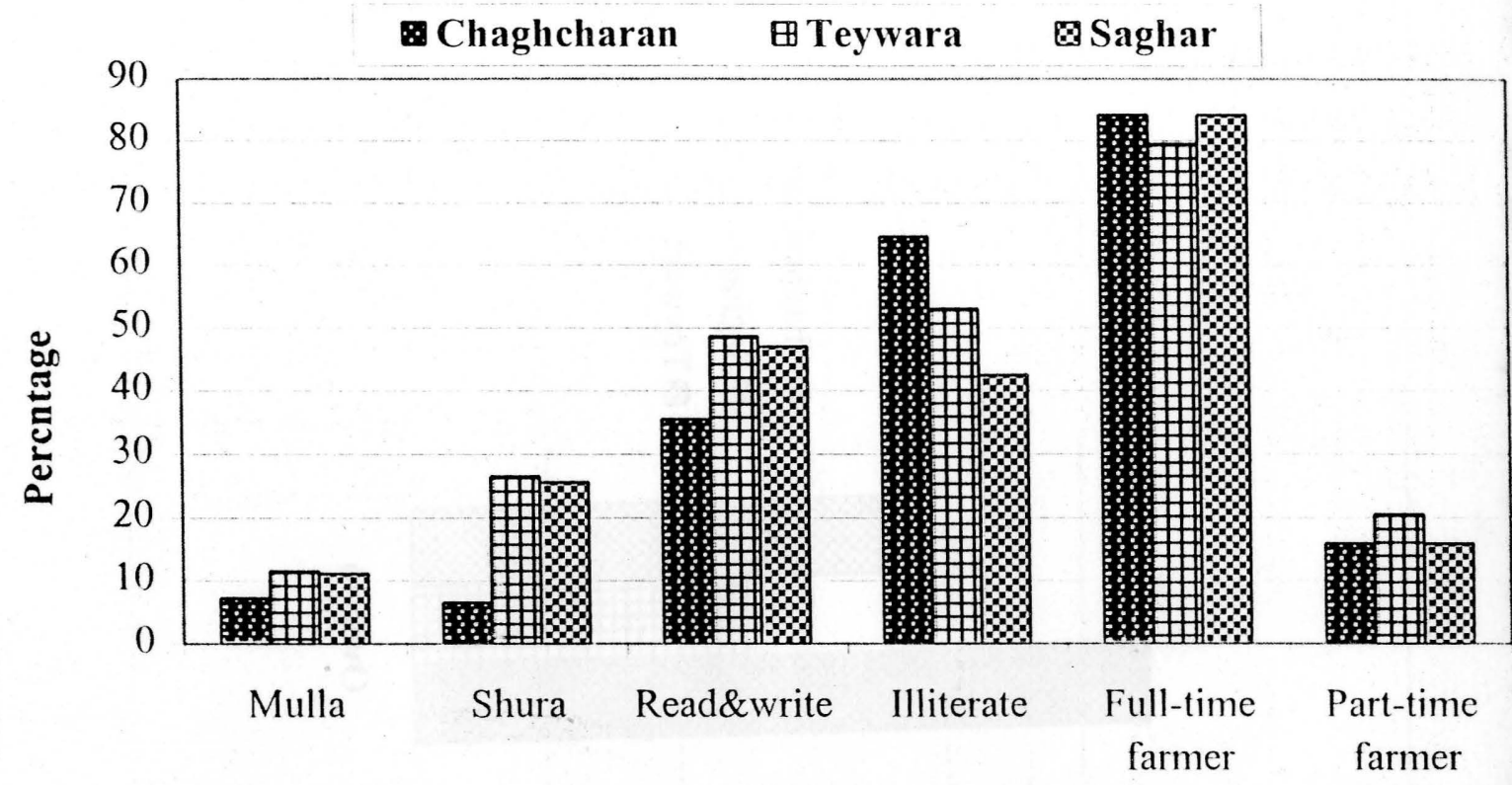

Figure I.2. The Distribution of Sample Farm Households by Tenure

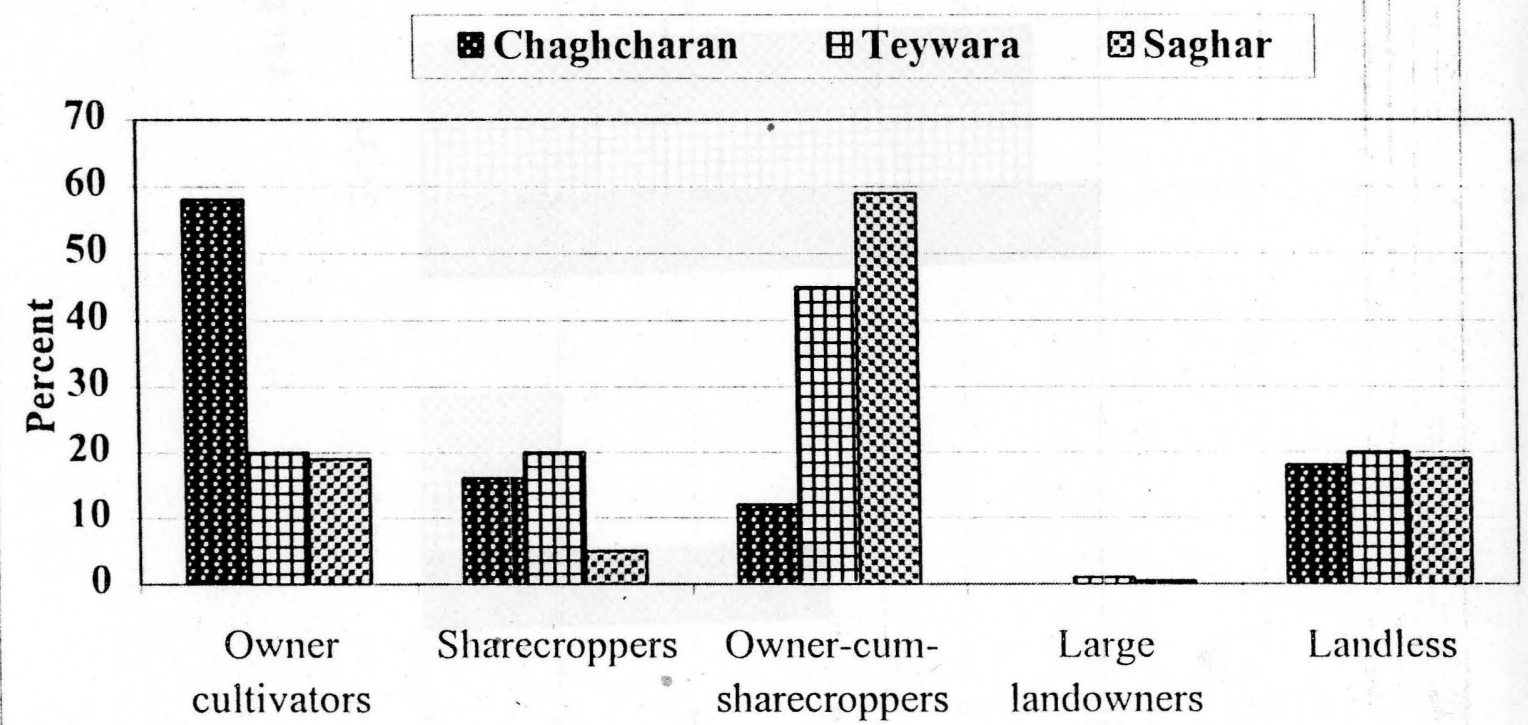


and enclosed in the annex. Some key-questions were designed in advance for RR $A$ and PRA, but specific questions were also conceived and asked on the spot using the maps as a guide. The average size of a group meeting was 25 for men and 15 for women. At times, the wellinformed individuals were dominating the dialogue. However, participants were let free to contradict and correct each other and eventually reach a consensus. Because of this the length of the discussions ranged from 1.5 to 3 hours.

In addition, direct observation was made to validate some of the information collected. The tcam has kept an open eye for patterns in resource exploitation and farmer behaviour while walking and driving through the villages. Besides this, "key infcrmants" were interviewed for information on broader issues, such as security, political balance, roads and accessibility, and availability of materials and farm inputs. The key informants included mullahs, clinic personnel, government employees, shopkeepers and staff working for NGOs.

The household level data was concerned with the farm/production unit. An attempt was made to select women from varied background - menopausal and childbcaring age, more or less affuent, widows, etc. However, it became apparent that there was no significant divide between rich and poor. The questionnaire was divided into various topics, such as childbearing/child mortality, assistance at deliveries, health problems during pregnancy, maternal mortality, breastfeeding/weaning, disability, morbidity and mortality of family members, consumption, education, and gender-specific division of labour and decision making practices.

\subsubsection{Questionnaires}

The survey also used formal questionnaires, both for household and community level. Both sets of questionnaires generated substantial amount of qualitative and quantitative information. The questionnaires were not tested, as had already been used by Afghanaid in Wardak and Nuristan.

\subsubsection{Sampling}

Sample villages and households were selected using a stratified sampling method (Figure 1.4). It is a two-stage sampling procedure in which villages were selected, based on distance from the 
district centre and, then, on distance from the main road. Using the first critcrion distance from the district centre - villages were stratified into areas "close" and "far" from the centre, as defined by local informants. Within these two strata, villages were classified according to their distance from the main road, i.e. villages close to the main road and villages far from the main road. Villages located at a distance, less than thour walk from the district centre and/or road, were classified as "close". Finally, a total of six villages were selected from each district; two from the strata "close to the district centre" (1 per sub-strata) and four from the strata "far from the district centre", two per sub-strata (see Table 1.1). Maps 2-4 also depict the location of sampled villages in the districts.

Sampling villages was constrained by the mobility of the population in which pcople during the summer leave their villages for five months. In many villages, especially in Chaghcharan, most of the households had left for the summer pastures, located at a radius of approximately three hours walk from the villages. Consequently, the survey in some villages was implemented in temporary settlement locations.

Table I. 1. Sampled Villages

District/Village

\section{Criteria}

Chaghcharan

Teywara

Saghar

\section{Close to District Centre}

1. Close to road

Shaykha

Khwaga Ghar

Titan

2. Far from road

Kandiwal

Narmy

Zargaran

Far from District Centre

3. Close to road

4. Close to road

5. Far from road

6. Far from road
Seyasang

Ihengaran

Tasragha Sofla

Tegha Timor
Sarolang

Pushta Kharistan

Yakhan

Quchi
Manak Olya

Khamin

Jarf

Khirkunak 
Distance and road conditions affected the size of samples per district. Distances between villages and districts are large and the roads are in bad condition. Most of the villages are also inaccessible by car and it takes hours and days by foot and horse to reach them. Due to these reasons, villages inaccessible by vehicle were not visited.

Figure I. 4. Stratified Sampling for Village Selection

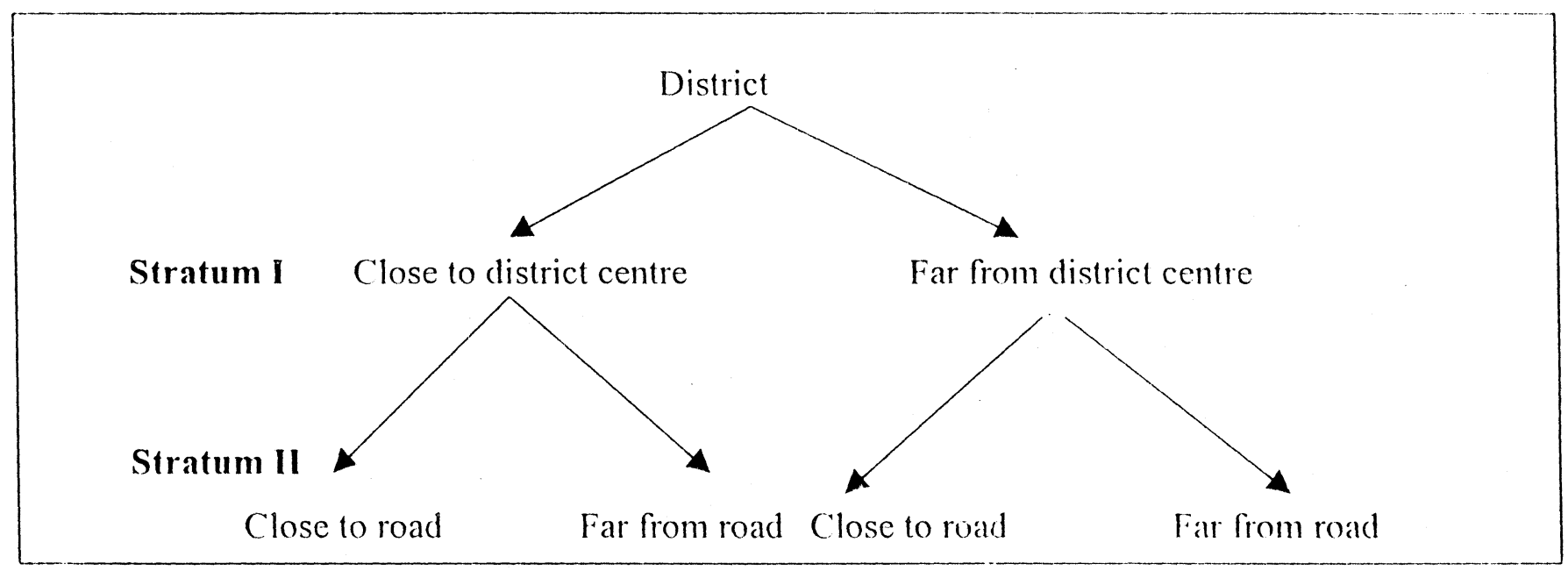

Following the sampling procedure described above, 9 household heads (male) and 8 females from different households were selected from each community gathering and formal questionnaires were administered to them. In selecting the household heads, the procedure followed was first to list the heads of houscholds participating in the group discussion. The sample households were then located in the agrarian economy on the basis of the variable "farm status". From each stratum - owner, owner-cum-sharecropper and sharecropper proper - households were randomly selected and interviewed. The male farmers were interviewed on issucs like agriculture, marketing, credit and saving, livelihood security, consumption and expenditure and sources of income. Women were selected according to two criteria, skilled vs unskilled and old (>45 years) is young (childbearing). In practice, it turned out that all women were skilled and only the latter criteria was applicable. There was no cultural restriction in interacting with women. $\wedge$ female expatriate who was accompanied by a male Afghan surveyor/translator interviewed the women. The fieldwork was completed in two weeks and the team was able to intervicw 169 houscholds from Chaghcharan, Teywara, and Saghar districts - an average of 9 households a village and 56 a district. 


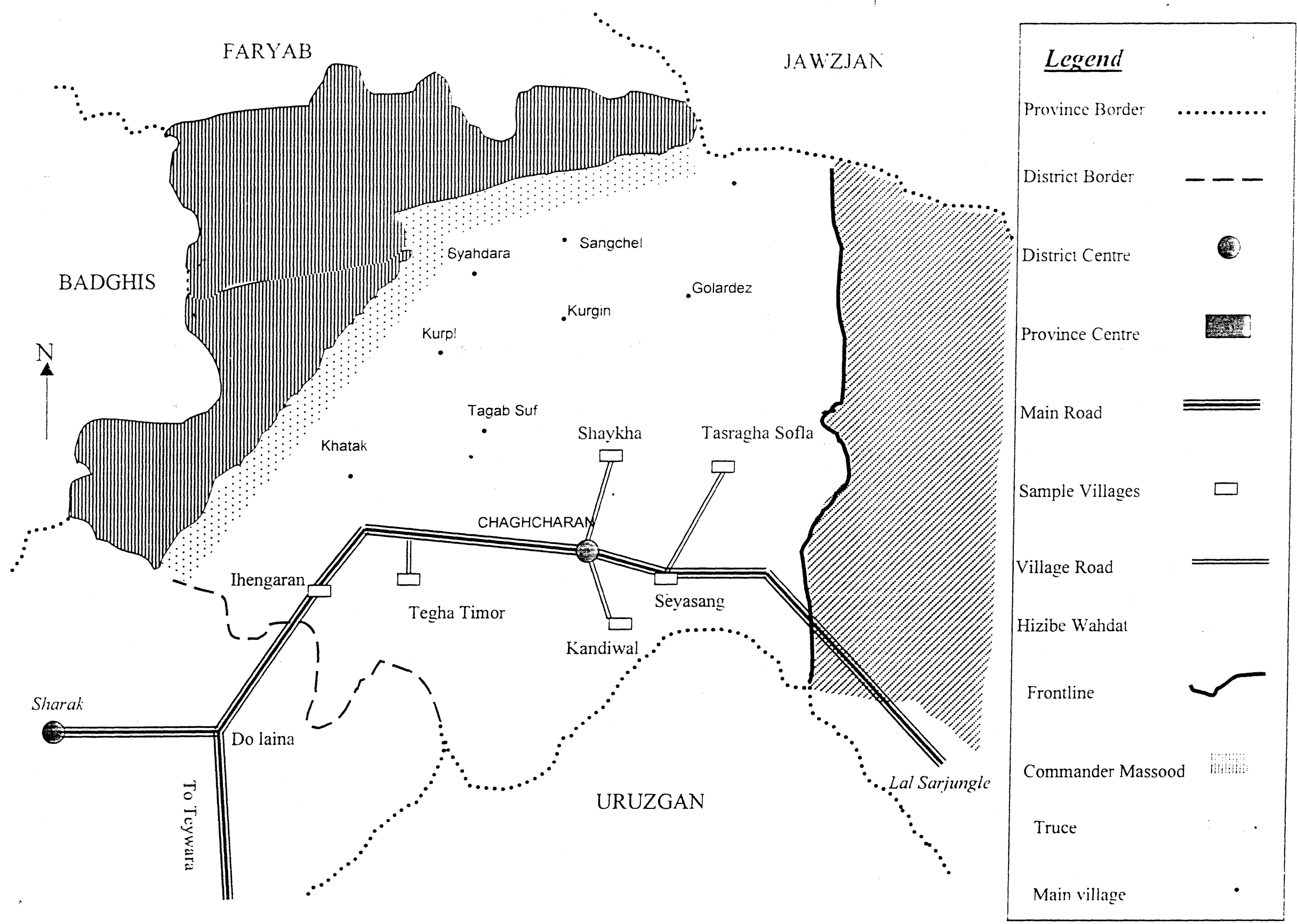

9

Map 2. Chaghcharan District 


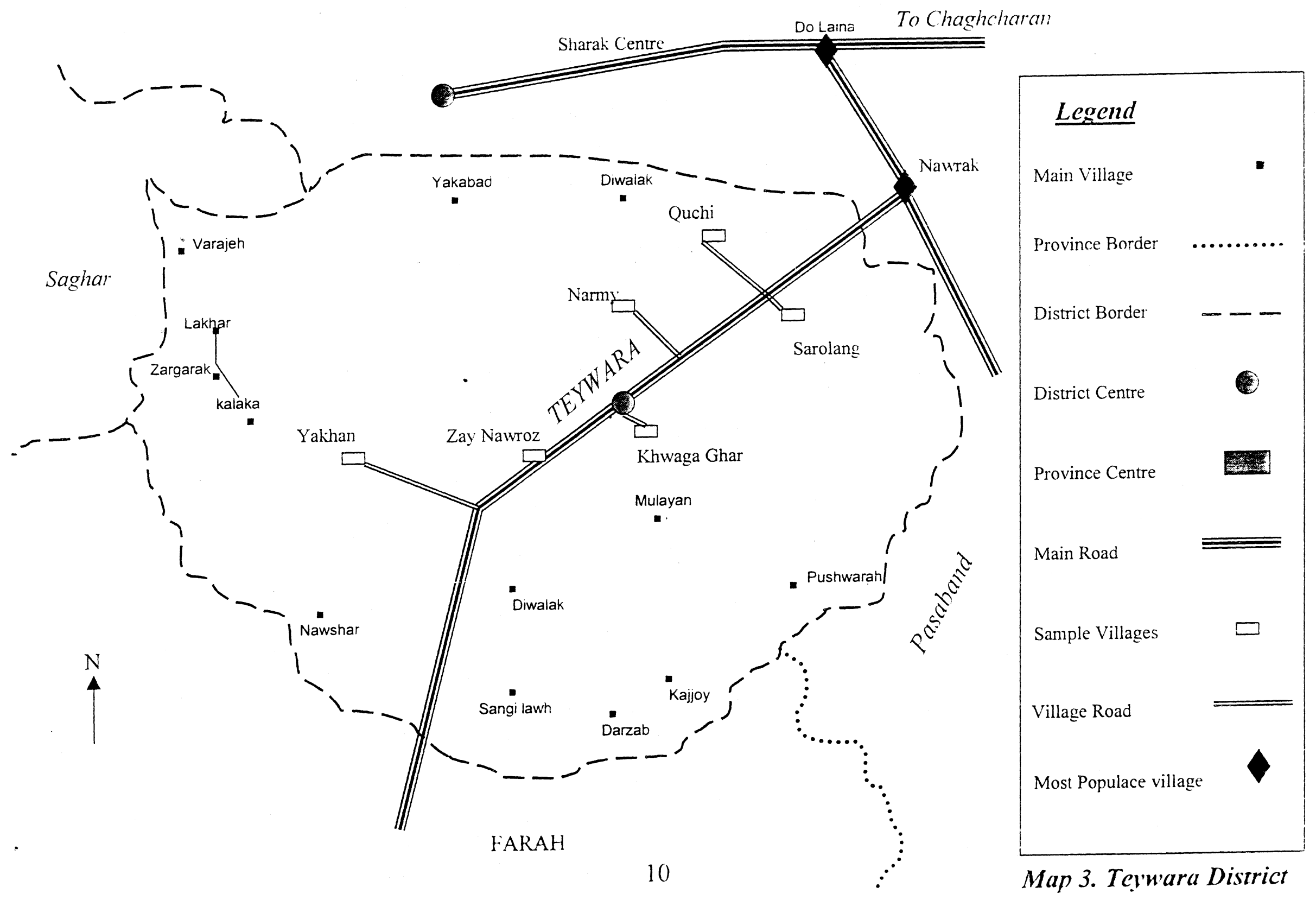




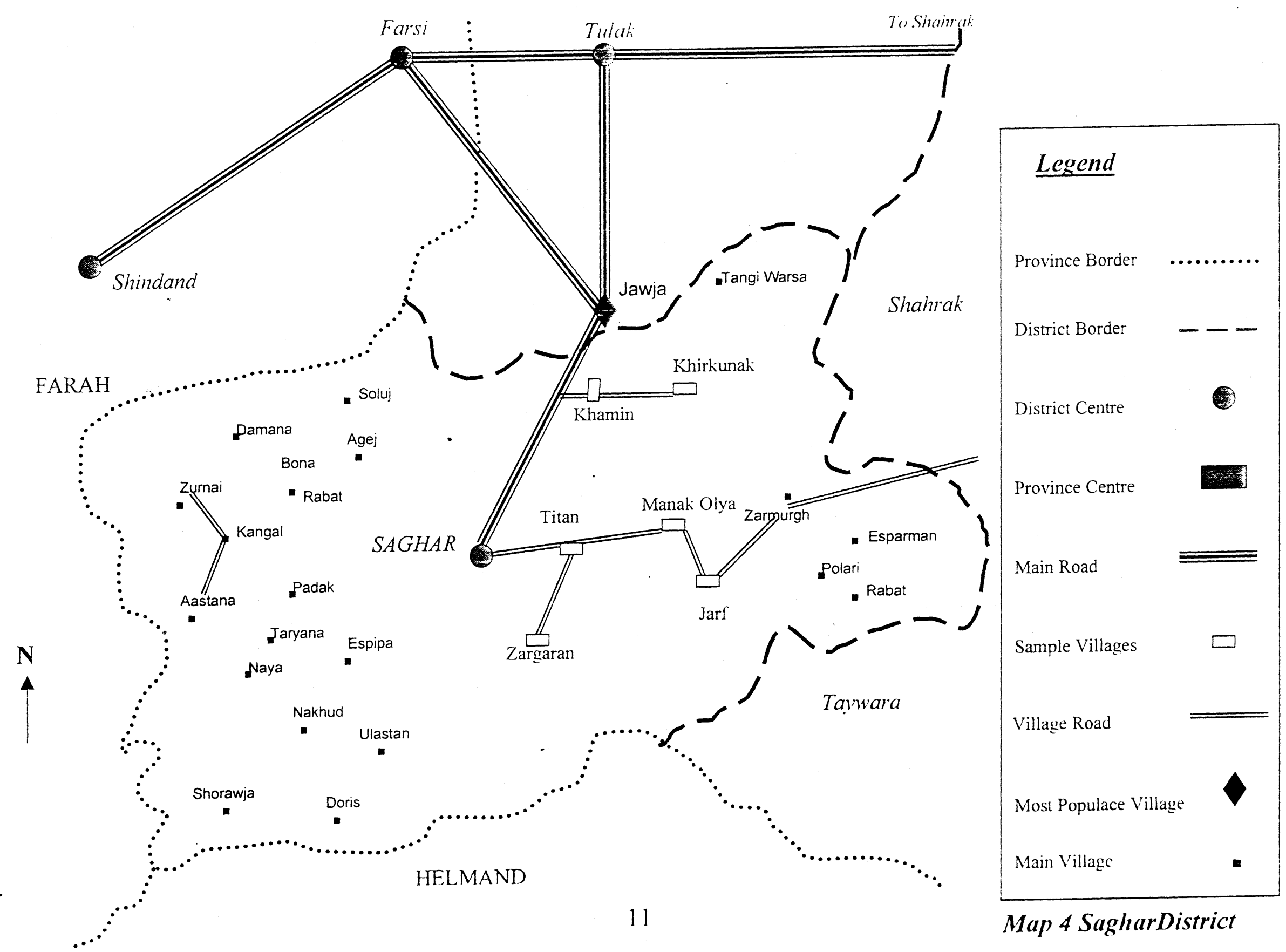




\subsubsection{The Survey Team}

The survey team members were from E/O CA, CHA, IAM and AAD and comprised a rural development specialist, a midwife, a doctor, an agriculturist and engineers. The team discussed the methodology and studied the questionnaires before travelling to the field. Part of the planning was also done in Herat - e.g. mapping, criteria for sample selection, etc. Each agency has taken the lead in the survey, as indicated below.

\begin{tabular}{|l|l|}
\hline \multicolumn{1}{|c|}{ Sector } & Responsible Organisation \\
\hline $\begin{array}{l}\text { Agriculture (crop and livestock), Health and Sanitation, } \\
\text { Income and Expenditure, Common Property Management }\end{array}$ & AAD \\
\hline Gender and Women Issues & EO/CA and CHA \\
\hline History and Security & EO/CA \\
\hline District Background & EO/CA \\
\hline
\end{tabular}

The survey was implemented in two weeks: 3 rd to $16^{\text {th }}$ of July. The team was divider into three groups - one group covered gender, the other two facilitated the group discussions and implemented the household survey. After a day's. work, the team checked the questionnaires and exchanged views and experiences and sought further clarification on issues that were not clear enough during the day.

\subsubsection{Data Analysis and Report Writing •}

Owing to the volume of information collected and the need to process the data with computers, the report was not drafted in the field. However, generating the final report has taken longer than anticipated. Following the security alert in Peshawar in August, the team leader charged with this task left AAD before finalising the report. Other AAD expatriate staff also stayed away from Peshawar for a while. Because of this unforeseen development, the production of the report was delayed by about two months:

All the data were entered in databases created in "ACCESS". The data were then queried and exported to "EXCEL" for statistical analysis and graphing. The analysis was kept to the level of descriptive statistics and simple bar charts. However, instead of just deriving averages - the usual 
prectice in RRA and PRA - the analysis aimed at showing variations between households. farm sizes and districts in the general practices, resource acquisition, income distribution, etc. by running "mean" tests. Classifications by farm size and status, household size, etc. are meant to improve data organisation and presentation, besides capturing variations in practices, resource acquisition and use. 


\section{PART II. GHOR PROVINCE AND THE CASE-DISTRICTS}

\subsection{Ghor Province}

\subsubsection{Population and History}

Ghor is one of the most impoverished and isolated provinces of $\Lambda$ fghanistan. It is a thinly populated province $\left(14\right.$ persons per $\left.\mathrm{km}^{2}\right)$ and ranks $7^{\text {th }}$ in size among the 30 provinces of Afghanistan. Located in the west-central highlands, Ghor is bordered by Jawzịan and Faryab in the north, Badghis in northwest, Herat in the west, Farah in the southeast. Helmand in the south and Urozgan and Bamyan in the southeast and in east respectively (see Map 1). Ghor is divided into seven administrative districts: Chaghcharan, Tulak, Shahrak, Passaband, Teywara, Saghar and Lal- u- Sirjangal. Chaghcharan, located on the Harirud river bank, is the provincial capital. The main language is Dari. An estimated $90 \%$ of the people of (Bhor are Tajiks. There are also Pashtuns who make the second largest ethnic group. Hazaras, practicing Shia, reside mainly in Lal-ul-Sirjangal district and form the third major ethnic group in the province.

Historically, Ghor was one of the most renowned provinces of Afghanistan. It was the heartland of the Ghoriad Empire that ruled the region from 11 th to 13 th century. (ihoriad kings invaded India and managed to form a large empire stretching from Delhi to Eastern Iran and from Indian Ocean to Central Asia. Ghor lost its importance after the demise of the Ghoriad Empire and has never regained the glory it achieved in the 11 th century.

\subsubsection{Major Livelihood}

Agriculture, livestock and off-farm employment are the major sources of livelihood. More than $80 \%$ of the inhabitants are dependent on agriculture and animal husbandry for their livelihood. An estimated $70-85 \%$ of the land is rainfed. Agricultural technology is simple and backward. Lack of traction power, irrigation infrastructure, improved seeds and a total absence of extension services are evident throughout the province. People cultivate mainly local varieties of wheat and barley, and some potatoes on the irrigatcd fields. In areas where there is more irrigated land, people grow, besides grains, fruit and nut trees. In all the three districts people market only a very small portion of their wheat output. In Saghar, people sell dry fruit, cumin, and nuts in the local bazaar. Iowever, agricultural marketing is constrained by the 
size of marketable surplus, which is meager, and by poor road condition. The latter accounts especially for Saghar district, where there is a high potential to sale dry fruit in Herat and get better income but owing to lack of accessible roads surpluses are sold locally.

It is probably the case that livestock is more important to livelihood than agriculture in areas where there is insufficient water for cropping. Though popular and well rooted in the history, animal husbandry is a risk-prone occupation due to the high incidence of animal disease in the province and the lack/poor quality of veterinary services. Dairy products like kurut (dry yoghurt) and gee are sold locally for cash or exchanged for kind. Wool is used to make carpets and gilims, and sold at the local bazaars or to visiting traders. In the summer season, women earn money through spinning wool for the kutchis.

Besides agriculture and livestock, people earn income from off-farm employment. Many go, seasonally, for two or more months to Helmand to work on the poppy fields. Others send their children to Herat, Pakistan and Iran to seek work, particularly during the long winter months when supplies dwindle and food insecurity ensues.

\subsubsection{Roads and Supply Routes}

Ghor is mountainous; Ferozkoh, Siakoh and Band-e-Bayan mountains stretch from east to west across the province. The mountains have made Ghor one of the most inaccessible province in the country. The roads connecting the province to the rest of the country (Map II.1) are accessible by four-wheel drive during May to October. Most of the roads are closed in the long winter months - November to April - to any kind of traffic due to snowfall, rain and the general poor condition of the roads. Ghor is accessible from the west (Herat) by two roads; the road via Farsi and Tulak (south road or Farsi road) or via Obey and Chest-i-Sharif (north road or Yamagak road). The Yamagak road is approximately $300 \mathrm{~km}$ long and it takes 2-3 days from Herat to Chaghcharan. There are three main passes along this road - Yamagak, Shakhzak and Talkhaw - all of which are steep. The Farsi road is longer $(420 \mathrm{~km})$ and it takes 3 days to reach Chaghcharan. Drivers prefer this road to avoid climbing the steep passes. Both roads converge at Do Laena, east of Shahrak bazaar (Map 5) Safety on the roads is reasonably good; there are no mines (OMAR has surveyed the area); no armed gang men operate along the roads. 

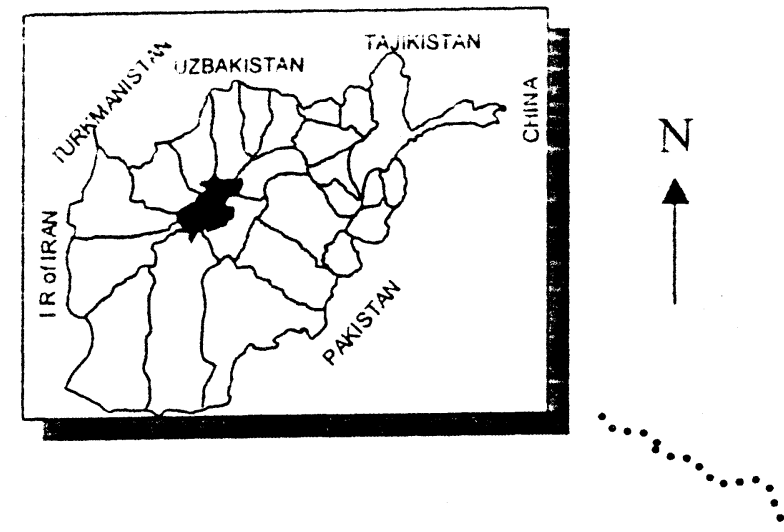

travere
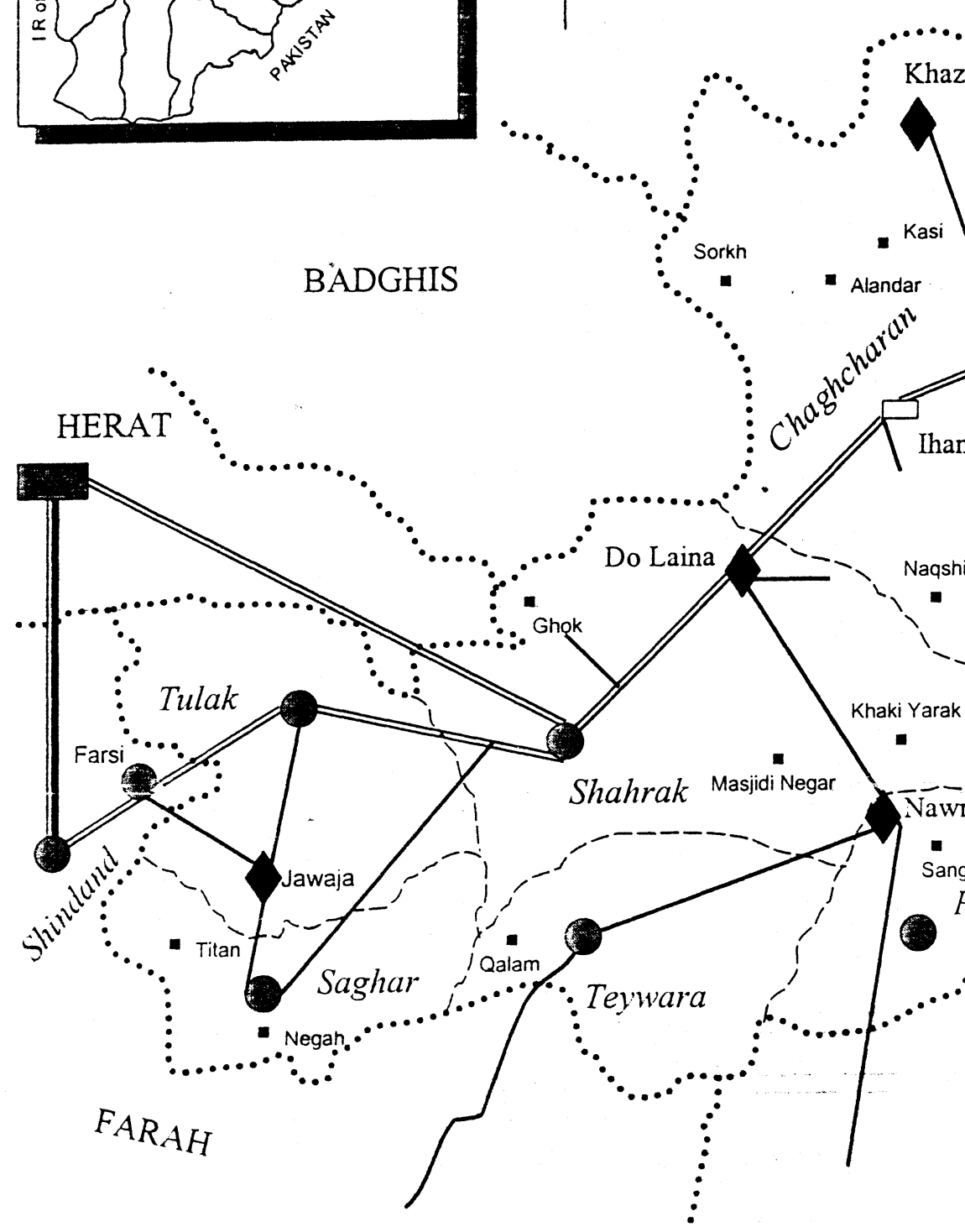

Pahlu Sang

Khaki Yarak

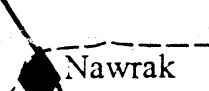

Sangan

${ }^{P}$

Pasaband

........

HELMAND 
From the east, Ghor is accessible via the Chaghcharan-Kabul road; however, this road crossed the frontline in Lal and was closed at the time of the survey. From the south. Ghor is accessible via the Sahrak-Kandahar highway that passes through Passaband and Teywara. This road remains open to traffic late in the winter.

There are no coaches and buses operating between Ghor and Herat. Only trucks and lorries, heavily loaded, haul goods and passengers. The average speed is $18 \mathrm{~km} / \mathrm{hr}$. Traffic density is reasonable, considering the condition of the roads - about 10 trucks a week in Teywara and Chaghcharan. and 4 trucks per week in Saghar. Transport cost to Ilerat is $200,000 \mathrm{Afs}$ per person.

The district roads are in extremely bad condition, with an average speed of $20 \mathrm{~km} / \mathrm{hr}$. There are only a few village roads; the majority of the villages are not accessible by car and it takes hours and days by horse to reach them.

Besides roads, there is a $1.9 \mathrm{~km}$ long graveled airfield in Chaghcharan. $\triangle$ report by I $\triangle M$ (IAM 1997) indicates that the surface of the airfield is in good and even condition. Military transport aircraft use the airfield regularly. The airfield is open for traffic in the wintertime to bring in goods and supplies.

\subsubsection{Security and Political Balance}

Being situated in the central highlands and surrounded by inhospitable mountains, Ghor did not witness many military campaigns by the Soviet army. The centre of the province. Chaghcharan. was controlled by the Communist regime until April 1992 while the various Mujahiddin groups contested for control of the districts and rural areas. After April 1992. (jhor was ruled by the Mujahiddin who continued to fight among themselves. The civil war has caused some people to flee, either to safer areas within the province or to other provinces. $\Lambda$ few also immigrated to Iran and Pakistan. Compared to other provinces in the country, population movement, as a result of the war. was not very drastic in Ghor. Recently, some families from Lal-u-Sirjangle. victimised by the internal fighting between the various armed groups and the economic blockade by the Taliban, have fled to Herat and Iran. 
At the time of the survey, Taliban controlled six of the seven districts of the province. Lal-uSirjangal district, located in the east of Chaghcharan, was the only district held by Hezb-eWahdat. The area to the north of Chaghcharan and Shahrak was also contested between the Taliban and various commanders, some operating in alliance with the opposition in the north. (see Map 6 for frontline positions). However, there were no active frontline positions and no serious fighting was reported in and around the province. In the districts of Passaband and Teywara (the former provincial capital) there were some isolated pockets of resistance to Taliban. Reports also indicated armed clashes between the nomadic kutchis and the native population in the villages east and north of Chaghcharan, arising from the use of grazing land. A great number of kutchi nomads seasonally migrate to Ghor from Farah and other western provinces at the onset of the spring. Despite this localised conflict, the security situation in the province was calm and Taliban were gaining ground.

\subsubsection{Material and Inputs}

Bazaars are stocked with basic food items. Fuel can be purchased from the main bazaar, but there is a high probability that it would be adulterated with water. There are no spare parts for four-wheel vehicles. Some DAP and urea fertilizer can be purchased but prices are too high for most farmers. Farmers do not have access to improved seed and agro-chemicals.

\subsubsection{Public Institutions}

There are few government institutions in Ghor: the Department of Rural Development, Public Health, Foreign Affairs, Information and Culture, Agriculture and Irrigation, Communication and Finance. However, these institutions are nominal for they do not offer any service to the public. The survey team has met with the provincial deputy governor in Chaghcharan and other officials of the two other surveyed districts.

\subsubsection{Mine}

Ghor is classified by the UN Mine Action Programme as a low priority area with a total of 0.97 square kilometer mine contaminated area (Mine Action Work Plan, 1998). Nevertheless, this survey team was told of several recent mine accidents in Chaghcharan. Most of the mines have been planted during the infighting between the different Mujahiddin groups and the Taliban. In 
-Teywara. the team was advised by the district administrator to avoid the road between Teywara and Passaband due to landmines. The team did not observe any mine awareness programme or demining activities during the survey.

\subsubsection{Aid Work}

Ghor has received little assistance from the aid community. $\Lambda$ feiv NGOs have some ad hoc projects here and there. DACA $\triangle \mathrm{R}$ has a drinking water project in the centre of 'Tulak district. MSF-Holland has a few staff members in Tulak carrying out need assessment survey. Ansari (a Herat based Afghan NGO) is installing drinking water wells in Shahrak centre. The Dutch Committee for Afghanistan (DCA) has animal clinics in six districts. Its operation does not cover the entire province, however. UNICEF has an immunizaion programme, channeled through the Ministry of Public Health. As vaccines are difficult to keep without refrigerators, coverage is restricted to those villages accessible by car (estimated $<25 \%$ of the province). CHA (Health Programme) too was interested to work in Teywara and Shagar districts; IAM (Community Development Programme) indicated its interest in opening an office in Chaghcharan.

\subsection{The Case-Districts}

Table II.1, below, provides a summary of the key indicators about the case-districts.

\begin{tabular}{|c|c|c|c|}
\hline \multirow[t]{2}{*}{ Indicators } & \multicolumn{3}{|c|}{ - District } \\
\hline & C'haghcharan & Teywara & Saghar \\
\hline $\begin{array}{l}\text { Distance from the } \\
\text { province centre }\end{array}$ & $0 \mathrm{~km}$ & $198 \mathrm{~km}$ & $247 \mathrm{~km}$ \\
\hline Distance from Heart & $489 \mathrm{~km}$ & $539 \mathrm{~km}$ & $352 \mathrm{~km}$ \\
\hline Population 1996 & 104,000 & 63,600 & 54.700 \\
\hline $\begin{array}{l}\text { Ethnic group } \\
\text { composition }\end{array}$ & $\begin{array}{c}\text { Tajik } 95 \% \\
\text { Pashtun 5\% }\end{array}$ & $\begin{array}{c}\text { Tajik } 60 \% \\
\text { Pashtun d } 0 \%\end{array}$ & $\begin{array}{l}\text { Tajik } 90 \% \\
\text { Pashtun } 10 \%\end{array}$ \\
\hline $\begin{array}{l}\text { Religious } \\
\text { denomination }\end{array}$ & Sunni 100\% & Sumni $100 \%$ & Sumni $100 \%$ \\
\hline Security situation & $\begin{array}{l}\text { Front-line between Taliban } \\
\text { and Hezbi Wahdat in the } \\
\text { East. Armed group of ex- }\end{array}$ & $\begin{array}{l}\text { North-east controlled by } \\
\text { ex-commanders of former } \\
\text { government but a truce }\end{array}$ & $\begin{array}{l}\text { (iond: no fromiline. no } \\
\text { armed groups. }\end{array}$ \\
\hline
\end{tabular}




\begin{tabular}{|c|c|c|c|}
\hline & $\begin{array}{l}\text { commander of Masood in } \\
\text { the North; they signed a } \\
\text { truce with the Taliban }\end{array}$ & $\begin{array}{l}\text { has been signed between } \\
\text { them and the Taliban }\end{array}$ & 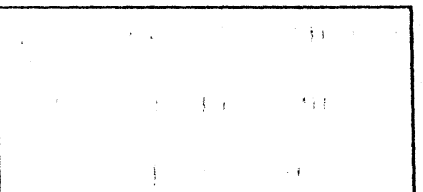 \\
\hline Community rivalry & $\begin{array}{l}\text { Conflict between kutchis } \\
\text { and local people. Potential } \\
\text { conflict between Pashtun } \\
\text { and Tajik tribes }\end{array}$ & No & No \\
\hline Accessibility & $\begin{array}{c}\text { One road Herat - } \\
\text { Chaghcharan through } \\
\text { Tulak. Closed for } 6 \text { months } \\
\text { during the winter (Nov. to d } \\
\text { early May) }\end{array}$ & $\begin{array}{c}3 \text { roads: Farah - Teywara. } \\
\text { Kandahar - Teywara, and } \\
\text { Herat- Teywara. Closed } \\
\text { during the winter (Nov. to } \\
\text { early May) }\end{array}$ & $\begin{array}{c}2 \text { roads: Herat - Farsi - } \\
\text { Saghar and Herat - Tulak } \\
\text { Saghar. Closed during the } \\
\text { winter }\end{array}$ \\
\hline Inter-district roads & $\begin{array}{c}\text { Only few villages } \\
\text { accessible. Overall bad } \\
\text { condition and closed during } \\
\text { the winter }\end{array}$ & $\begin{array}{c}\text { Only few villages } \\
\text { accessible. Overall bad } \\
\text { condition and closed } \\
\text { during the winter }\end{array}$ & $\begin{array}{l}\text { Only few villages } \\
\text { accessible. Overall bad } \\
\text { condition and closed } \\
\text { during the winter }\end{array}$ \\
\hline Mines & None & None & None \\
\hline Public transport & $\begin{array}{l}\text { Only trucks when the road } \\
\text { is open; } 30 \text { per month; } a \\
200,000 \text { Afs per person to } \\
\text { Herat }\end{array}$ & $\begin{array}{l}\text { Only trucks when the } \\
\text { road is open; } 40 \text { per } \\
\text { month; @ 200,000 Afs } \\
\text { per person to Herat }\end{array}$ & $\begin{array}{l}\text { Only limited number of } \\
\text { trucks when the road is } \\
\text { open: @ } 200,000 \text { Afs per } \\
\text { person to Herat }\end{array}$ \\
\hline Safety on roads & Good & Good & Good \\
\hline Permit required & No & No & No \\
\hline $\begin{array}{l}\text { Status of physical } \\
\text { environment }\end{array}$ & $\begin{array}{l}\text { Overgrazed; deforestation } \\
\text { and erosion }\end{array}$ & $\begin{array}{c}\text { Overgrazed; deforestation } \\
\text { and erosion }\end{array}$ & $\begin{array}{c}\text { Overgrazed: deforestation } \\
\text { and crosion }\end{array}$ \\
\hline Fuel source & Bushes, animal dung & Bushes, animal dung & $\begin{array}{l}\text { Bushes, animal dung; } \\
\text { hydroelectricity for } \\
\text { lighting }\end{array}$ \\
\hline $\begin{array}{l}\text { Irrigation } \\
\text { infrastructure }\end{array}$ & Canals & Kareezes and springs & Springs \\
\hline $\begin{array}{l}\text { Proportion of } \\
\text { households food } \\
\text { insecure }\end{array}$ & & & \\
\hline Sources of income & $\begin{array}{c}\Lambda \text { griculture, livestock, } \\
\text { carpets, gilims, wage labour }\end{array}$ & $\begin{array}{l}\text { Agriculture, livestock. } \\
\text { Off-farm employment. } \\
\text { remittance, carpets, }\end{array}$ & $\begin{array}{c}\text { Agriculture, horticulture. } \\
\text { off-farm employment. } \\
\text { carpets, gilims }\end{array}$ \\
\hline
\end{tabular}




\begin{tabular}{|c|c|c|c|}
\hline & & gilims. dry fiuil & \\
\hline Ixpont items & $\begin{array}{l}\text { Dairy products, gilims, } \\
\text { carpets }\end{array}$ & $\begin{array}{l}\text { Campets, gilims, dairy } \\
\text { products, cumin, timber. } \\
\text { clover seed }\end{array}$ & $\begin{array}{l}\text { Thuil (ficshtdry), muts. } \\
\text { carpets, gilims, cumin. } \\
\text { (airy products }\end{array}$ \\
\hline handicraft & $\begin{array}{c}\text { Carpets, gilims, hats, } \\
\text { embroidery, socks, gloves, } \\
\text { beadwork }\end{array}$ & $\begin{array}{l}\text { Carpets, gilims, hats. } \\
\text { embroidery }\end{array}$ & $\begin{array}{l}\text { Carpets, gilims, } \\
\text { cmbroidery, rugs, hats }\end{array}$ \\
\hline $\begin{array}{l}\text { Percent of people } \\
\text { still refugees }\end{array}$ & 2.9 & 16.8 & 5.5 \\
\hline Aid agency & $\begin{array}{c}\text { Afghan Red Crescent } \\
\text { Socicty has a clinic. DCA }\end{array}$ & DCA,M()PIIINI(T:I) & IA.MI)PII(UNICII) \\
\hline $\begin{array}{l}\text { No. of functioning } \\
\text { primary schools }\end{array}$ & 3 & () & () \\
\hline No. of clinics & 1 & 1 & $\mathrm{~T}$ \\
\hline No. of hospitals & 1 & 0 & () \\
\hline $\begin{array}{l}\text { No. of trained } \\
\text { medical doctors }\end{array}$ & $5(1)$ & 0 & 2 \\
\hline No. of TBAs & $\begin{array}{c}2-3 \text { in each village. All not } \\
\text { trained }\end{array}$ & $\begin{array}{c}2-3 \text { in each village. All } \\
\text { not trained }\end{array}$ & $\begin{array}{c}2-3 \text { in each village. } A \pi 1 \\
\text { not trained }\end{array}$ \\
\hline Immunisation & MOP'i (polio, tetanus) & MOPII(I)TP & Mopli (polio, tetanus) \\
\hline Pharmacies & ()nly in big villages & Only in big villages & ()nly in big villages \\
\hline $\begin{array}{l}\text { Source of drinking } \\
\text { water }\end{array}$ & Canal, river, spring & $\begin{array}{l}\text { Kareezes, river. canal. } \\
\text { spring }\end{array}$ & Spring river \\
\hline $\begin{array}{l}\text { No. of veterinary } \\
\text { clinics }\end{array}$ & 0 & 4 & 1 \\
\hline \multicolumn{4}{|l|}{ Child mortality rate } \\
\hline \multicolumn{4}{|l|}{ Birth rate } \\
\hline Commodities in shop) & $\begin{array}{c}\text { Food items, clothing, basic } \\
\text { necessities }\end{array}$ & $\begin{array}{l}\text { Food items. clothing. } \\
\text { basic necessities }\end{array}$ & $\begin{array}{l}\text { Food items, clothing. } \\
\text { basic necessities }\end{array}$ \\
\hline arm input & Urea in small quantity & $\begin{array}{c}\text { Urea and DAP: improved } \\
\text { seed from Ka mblate in } \\
\text { small quanty }\end{array}$ & $\begin{array}{c}\text { Trea and DAP in small } \\
\text { quantitics }\end{array}$ \\
\hline Iocal materials & Timber breaks & No construction matcrials & No construction materials \\
\hline Fucl and parts & $\begin{array}{c}\text { Petrol and diesel; no spare } \\
\text { parts }\end{array}$ & $\begin{array}{c}\text { Petrol and diesel: no spare } \\
\text { parts }\end{array}$ & $\begin{array}{c}\text { Petrol and diesel: no spare } \\
\text { parts }\end{array}$ \\
\hline
\end{tabular}




\begin{tabular}{|l|c|c|c|}
\hline $\begin{array}{l}\text { No. of importing } \\
\text { raders }\end{array}$ & $\begin{array}{c}30 \text { per month during } \\
\text { summer; one trader makes } \\
5-6 \text { trips per year }\end{array}$ & 40 per week & 16 per week \\
\hline Skilled labour & $\begin{array}{c}\text { Masons, carpenters, } \\
\text { blacksmiths, tailors, metal } \\
\text { workers of varying } \\
\text { numbers; in sample 60 }\end{array}$ & $\begin{array}{c}\text { Masons, carpenters, } \\
\text { blacksmiths, tailors, metal } \\
\text { workers of varying } \\
\text { numbers; in sample 90 }\end{array}$ & $\begin{array}{c}\text { Masons, carpenters, } \\
\text { workers of varying } \\
\text { numbers; in sample } 48\end{array}$ \\
\hline
\end{tabular}

\subsubsection{Land and Population}

The land use pattern in the districts before the war (Table II.2) closely approximates the average for the province. Nearly a third of the land in each district was under cultivation. Fallow land accounted for a tenth of the total land. By far the largest share was taken by pasture indicating, on the one hand, the absence of population pressure on land and, on the other, the agro-pastoral nature of the economy.

Table II.2. Percentage Distribution of Land Use before the War

\begin{tabular}{|l|l|l|l|l|l|}
\hline District & Fallow & $\begin{array}{l}\text { Under } \\
\text { Cultivation }\end{array}$ & Forests & Pasture & $\begin{array}{l}\text { Total ('000 } \\
\text { jeribs)' }\end{array}$ \\
\hline Chaghcharan & 9.84 & 35.42 & 25.31 & 29.43 & 166 \\
\hline Tey'vara & 9.69 & 25.44 & 0.00 & 49.78 & 934 \\
\hline Saghar & 11.03 & 39.36 & 0.00 & 49.61 & 94 \\
\hline Total ('000) & 10.75 & 29.34 & 3.85 & 56.06 & 2,918 \\
\hline
\end{tabular}

one jerib $=0.2$ ha.

Source: Derived from Table 2. page 136, Heart, Historical and Political Gazetter of Afghanistan, 1975

Overtime, the land use pattern has changed marginally. In Table II.3, we observe that only a tiny proportion of the area is under cultivation. Most of the land is rainfed and grazing land, and only a small portion of the total land area consists of irrigated agricultural land. In Chaghcharan, only $5.7 \%$ of the total land is irrigated agriculture; in Teywara this proportion is slightly higher, $8.3 \%$ (FAO, 1997). Saghar district has relatively more irrigated agricultural land, as opposed to grazing. Rainfed agricultural land accounts for about $46 \%$ of the total agricultural land area of the village territories in the three districts. 
Table 11.3. Land Use in Chaghcharan and Teywara Districts, circa 1997 (Percentage) I.and cover type

Chaghcharan

Teywara

\title{
A gricultural
}

- Fruit trees

\author{
()
}

0.1

- Vineyards

()

- Gardens

()

- Irrigated: Intensively cultivated 2 crop/year

- Irrigated: Intensively cultivated $1 \mathrm{crop} / \mathrm{year}$

- Irrigated: Intermittently cultivated

- Rainfed crops (flat lying areas)

- Rainfed crops (sloping areas)

\section{Forest and rangeland}

- Pistachio forest

$\begin{array}{ll}0 & 0 \\ 0 & 0 \\ 0 & 0 \\ 0 & 0\end{array}$

- Natural forest (closed area)

83.0

- Rangeland (grassland/shrubs)

\section{Barren Land}

- Rate out crop /bare soil

- Sand cover areas

- Sand dunes

\section{Water bodies and other}

- Marshland permanently inundated

- Marshland seasonal

0 0

- Permanent snow

Source: FA(), 1997

With the growth in population (Table II.4) and the shortage of irrigation water restricting expansion of agricultural land. farmers have to intensify agriculture or seck employment (temporary) elsewhere. 
Table II.4. District Population, 1958 - 1996

\begin{tabular}{lccc}
\cline { 2 - 4 } District & $1958^{\mathrm{a}}$ & $1990^{\mathrm{b}}$ & $1996^{\mathrm{c}}$ \\
\hline Chaghcharan & 26,316 & 110,441 & 104,000 \\
Shahrak & 13,094 & 51,550 & 54,700 \\
Saghar & 6,418 & 23,277 & 24,700 \\
Teywara & 19,668 & 59,964 & 63,600 \\
Lal-Sarjungle & 17,652 & 81,062 & 86,000 \\
Tulak & 9,362 & 35,072 & 37,200 \\
Pasaband & 12,959 & 56,637 & 60,100 \\
\hline & 105,469 & 418,003 & 430,300
\end{tabular}

\begin{tabular}{ll}
\hline Source: & a. Central Statistics Office, 1975 \\
& b. UNIDATA, 1991 \\
& $\quad$ c. Central Statistics Office, 1996
\end{tabular}

\subsubsection{Agriculture}

Agriculture is practiced in the irrigated valleys and is typified by small-farm, low-input use; small returns and a low level of technology. Cooler climate and shorter growing season restrict agriculture to one cropping a season. Chaghcharan experiences heavy rain and snowfall during the spring and winter seasons. Teywara and Saghar, by contrast, enjoy more favourable climatic condition. Hence, these two districts have relatively better agricultural potential. In the irrigated fields, wheat, potatoes, and some vegetables are cultivated. Fruit trees such as apricot, apple and walnut are widely grown; willow, poplar and plane trees can also be found in villages where there is irrigation water. In Teywara and Saghar, people also cultivate maize on a small scale. In the rainfed fields, barley and wheat are grown. In years with sufficient rainfall, temporary settlers grow wheat in the common grazing areas. The soil and climate in the southern districts, Saghar, and to some extent in Teywara, are also suited for orchards. Farmers grow different fruit and nut trees, such as apricot, apple, mulberry, cherry, pistachio and walnut. In Teywara, farmers are also grow timber trees for commercial production. In Chaghcharan district, some villages have recently started horticulture activities and grow apricot and apple trees in areas with sufficient water. 


\subsubsection{Agrarian System}

In Saghar and Teywara districts, owner-cum-sharecroppers make up the bulk of the population. In (hagheharan. we find a larger perentage of owner-cultivators and. as in the other districts, here too large landowners are few. Iandless houscholds account for a significant proportion. however (Table II.5. see also Figure II.2). Where the farmer tills the soil of a landlord, a tenancy arrangement is struck up. In most cases. all investment to be made on the crop is made by the landlord. Costs like land. fertilizer. seed. oxen. other inputs like tractor and agro-chemicals (if used), additional labour cost and irrigation water are all borme by the landlord. The farmer provides threshers and of eourse family labour. The output of this contract is split between the landlord and the farmer in the ratio of $3: 1$. in almost all cases.

Tahle II.5. Agrarian System of Sampled Villages (percentages)

$\begin{array}{lccc} & \text { Chaghcharan } & \text { Saghar } & \text { leywara } \\ \text { ()wner cultivators } & 56.8 & 20.7 & 18.8 \\ \text { Sharecroppers } & 15.1 & 19.6 & 4.9 \\ \text { Owner-cum-sharecroppers } & 12.5 & 45.9 & 58.7 \\ \text { Large landowners } & 0 & 0.8 & 0.2 \\ \text { Landless families } & 15.6 & 19.6 & 17.4\end{array}$

For Chaghcharan $>60$ jeribs; for the others $>20$ jeribs.

\subsubsection{Crop Enterprise}

Communities were asked to rank their key crop enterprises (Table II.6). In all the casedistricts. wheat is the single most important crop. Barley and potatoes rank secondary, with maize grown widely in Teywara and Saghar. Many houscholds grow more fruit trees than potatoes and, yet, potatoes are ranked higher because of their food and cash value. Fruit trees are not perecived to he important, because the output is not marketed. 
Table II.6. Ranking of Key Crop Enterprises (percentage)

Wheat Maize Barley Potato Fruit Alfalfa

\begin{tabular}{|c|c|c|c|c|c|c|}
\hline \multicolumn{7}{|l|}{ a) Chaghcharan } \\
\hline $1^{\text {st }}$ rank & 100 & & & & & \\
\hline $2^{\text {nd }}$ rank & & & 50 & 17 & & 17 \\
\hline $3^{\text {rd }}$ rank & & & 17 & 83 & & \\
\hline $4^{\text {th }}$ rank & & & 33 & & 33 & \\
\hline $5^{\text {th }}$ rank & & & & & 50 & \\
\hline Households growing & 100 & & 53 & 82 & 1 & 2 \\
\hline \multicolumn{7}{|l|}{ b) Teywara } \\
\hline $1^{\text {st }}$ rank & 100 & & & & & \\
\hline $2^{\text {nd }}$ rank & & 17 & 50 & 33 & & \\
\hline $3^{\text {rd }}$ rank & & 33 & & 66 & & \\
\hline $4^{\text {th }}$ rank & & 33 & 25 & & 25 & 17 \\
\hline $5^{\text {th }}$ rank & & & 25 & & 75 & \\
\hline Households growing & 100 & 70 & 96 & 98 & 9 & 1 \\
\hline \multicolumn{7}{|l|}{ c) Saghar } \\
\hline $1^{\text {st }}$ rank & 100 & & & & & \\
\hline $2^{\text {nd }}$ rank & & 17 & 33 & & 50 & \\
\hline $3^{\text {rd }}$ rank & & 33 & & 50 & 17 & \\
\hline $4^{\text {th }}$ rank & & 17 & & 50 & 33 & \\
\hline $5^{\text {th }}$ rank & & • & 50 & & & \\
\hline Households growing & 100 & 42 & 35 & 60 & 76 & \\
\hline
\end{tabular}

Note: Data on number of households growing specific crops is retrieved at the community level and differs with data from the household level.

\subsubsection{Tree Plantation}

Farmers in Chaghcharan, Saghar and Teywara districts plant different varieties of poplar and chinar trees for timber, and willow varieties for fuel purposes (Table II.7). The trees are planted alongside the creeks and canals. In Saghar, willow trees are dominant. Growing trees for timber production is important in specific parts of Teywara, as logs of timber can be sold to visiting traders for a reasonable income. One poplar tree has a value of $500,000 \wedge \mathrm{fs}$, equal 
to 35,000 to $50,000 \wedge \mathrm{fs}$ per year [equivalent to $25-36$ Pak. Rs at current exchange rate] (WFP, 1997).

Table 1I.7. Tree Production

Chaghcharan Saghar Teywara

Communities involved in tree planting (\%)

10)

i(0)

100)

Communities involved in timber production (\%)

67

33

67

Mean number of trees planted

- 1996

2983

5033

3342

- 1997

6533

5166

3158

\section{Mean number of timber logs produced}

- 1996

- 1997

569

25

923

One of the reasons for the low timber production in Saghar is the lack of irrigation water, as stressed by farmers. When irrigated land is scarce, timber trees compete with crops and fruit trees, and farmers in Saghar prefer growing fruit trees. Another problem farmers' face is insects and animals that attack the trees. All these constraints add up to a shortage of timber trees for roof construction. Table II.8 shows problems related to rooling timber as stressed by respondents in the different sampled villages.

Table II.8. Problems Related to Roofing Tiinber (ranks in percentage)

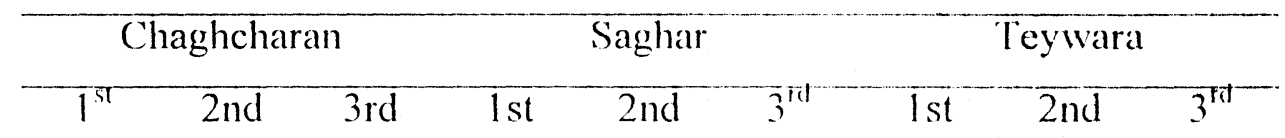

Lack of water

33

17

33

17

$1 \overline{7}$

Lack of timber

$17 \quad 17$

17

33

17

50

33

Pests

17

17

17

Flooding

Competing with fuel

Iligh prices

$17 \quad 17$ 


\subsubsection{Irrigation}

The distribution of irrigation water is thought to vary between locations and districts. The major irrigation infrastructure in Chaghcharan is canal that channels snow water from the mountains to the fields. Often, snow water is insufficient to irrigate all the land, leaving $65 \%$ of irrigated land of the sampled villages with insufficient water and an average of 280 jeribs of irrigated land per village rainfed (Table II.9). In Saghar, springs are the major source of water. Villages direct this water to the fields using ditches constructed from soil, but the lack of proper channeling infrastructure means half the irrigated lands of the sampled villages has inadequate water and an average of 135 jeribs irrigated land per village is now rainfed. In Teywara, villages have canals to bring water from the streams and rivers to their fields; they also have some kareczes. The average irrigated land per village is, however, low - only 123 jerib of land is sufficiently irrigated.

Table 1I.9. Status of Irrigated L and

\begin{tabular}{lccc} 
& Chaghcharan & Saghar & Teywara \\
\hline Main irrigation source & Canal & Spring & Canal, Kareeze \\
Average irrigated land area per village (jeribs) & 311 & 407 & 187 \\
Land abandoned (\%) & 15 & 46 & 41 \\
Land with insufficient water (\%) & 65 & 50 & 34 \\
\hline
\end{tabular}

The response from the farmer survey indicates that between 1 and 59 hours flow of water is required to irrigate one jerib land', suggesting low water flow (see Table II.10). Many of the intakes are either damaged or poorly maintained. Because canal intakes are constructed from local materials, they often do not withstand the spring season floods. Moreover, floods fill-up the canals and damage the kareezes. Many villages are arr behind with maintenance, exacerbated by the fact that many able-bodied men leave the villages for off-farm employment during the time of maintenance.

\footnotetext{
${ }^{1}$ From origin (intake, kareeze, spring) to the field.
} 
Table II. 10. Estimated Time Required to Irrigate one Jerib from I)ifferent Sources (in hours)

\begin{tabular}{|c|c|c|c|}
\hline & Chaghcharan & Saghar & Teywara \\
\hline \multicolumn{4}{|l|}{ From canal } \\
\hline At present & 4.2 & - & 1.1 \\
\hline 5 years ago & 4.2 & - & 1.1 \\
\hline 25 years ago & 3.9 & - & 1.1 \\
\hline \multicolumn{4}{|l|}{ From kareeze } \\
\hline At present & 9 & - & 27.9 \\
\hline 5 years ago & 9 & - & 36.7 \\
\hline 25 years ago & 9 & - & 43 \\
\hline \multicolumn{4}{|l|}{ From spring } \\
\hline$\Lambda t$ present & - & 10.6 & 58.7 \\
\hline 5 years ago & - & 11.8 & 48 \\
\hline 25 years ago & - & 12.2 & - \\
\hline
\end{tabular}

\subsubsection{Flood Protection}

Every year, farmers lose a great deal of agricultural land when their fields are inundated by flood. Though not a calamity, flooding still poses a major problem to farmers. In Chaghcharan, where there is no flood protection infrastructure of any kind, flooding has claimed $17 \%$ of the total arable land area of the sampled villages (Table II.11). Even in areas with some flood protection, the structures are not functioning, because they are made of makeshift local materials like wood.

Table II. 11. Flood Protection Status

\begin{tabular}{lcc} 
& Land abandoned due to flooding (\%) & Type of llood protection in villages \\
\hline Chaghcharan & 17 & None \\
Saghar & 12 & Retaining wall. protection wall. dike \\
Teywara & 13 & Retaining wall. protection wall \\
\hline
\end{tabular}




\subsubsection{Marketing Infrastructure}

Data on market infrastructure indicators is given in Table II.12. There are many small shops in all the districts. In Teywara alone, the suryey team has counted over 80 shops, located in two localities of the district. Shops sell some basic items, like clothing, foodstuff, fuel, soap, salt, matches, sweet. Some developed shops also sale Iranian and Afghan footwear, fuel and medicines. Most of the shopkeepers and traders are from the local population. A small number of traders and businessmen come from outside the prcvince, mostly from Kandahar and Herat. In Chaghcharan the owners of the booths are former government employees who, in the absence of formal sector employment, turned into trade to earn a living. Heads of households visit bazaars only on market days, mostly once or twice a month. People living in remote villages visit bazaars once every two or three months, the frequency of which tends to increase in the summer. Often surpluses are small to sale so bartering is the preferred mode of transaction.

Besides shops, there are also drugstores in all the district centres - up to six - in the case of Chaghcharan. There are also bakeries, butcher, some tinsmiths, carpentry and ironsmith shops, all located in the district centres.

Transport vehicles are hard to come by; only 2 transport vehicles in the sampled villages of Teywara district and none whatsoever in the sampled villages of the other two districts. It is not surprising that most villagers rank lack of motorised transport as the single most important obstacle to marketing. A close second is the poor condition of the roads, as villagers have to travel between 10 to 29 kilometres to sell their goods.

Given the topography and the virtual absence of transport system in the villages, there exist relatively high number of pack animals, mainly donkeys. Construction of new roads and improvement of existing ones can contribute immensely to the stralegy of poverty alleviation. This would also pave the way for traders to use vehicles to transport agricultural and commercial products, thus stepping up development. 
:Table II.12. Market Infrastructure in the Case-Districts

\begin{tabular}{|c|c|c|c|c|c|c|}
\hline & \multicolumn{2}{|c|}{ Chaghcharan } & \multicolumn{2}{|c|}{ Saghar } & \multicolumn{2}{|c|}{ Teywara } \\
\hline & Near & Far & Near & Far & Near & Far \\
\hline Mean number of traders/village & 1.3 & () & 2.7 & 1.3 & 0.3 & 1.7 \\
\hline Mean number of transport vehicles/village & () & () & () & () & 0.3 & 0.3 \\
\hline Transport : household (ratio) & 0.8 & 1 & 0.6 & 1.4 & 1 & 0.7 \\
\hline Mean distance to the market $(\mathrm{km})$ & 10.3 & 14 & 3.3 & 29 & 14 & 19 \\
\hline $\begin{array}{l}\text { Mean number of months road to market is } \\
\text { closed per year }\end{array}$ & 1.7 & () & 2.3 & 1.7 & 2 & 1.5 \\
\hline Main transportation problems to market & & & & & & \\
\hline - Lack of transport & 67 & 67 & 100 & 100 & & 67 \\
\hline - Bad road condition & 33 & 33 & 100 & 67 & 100 & 67 \\
\hline - High transport fare & 67 & 67 & 100 & & 100 & 33 \\
\hline - Heavy snow & & & & & & 33 \\
\hline
\end{tabular}

7 percentage frequency distribution

\subsubsection{Location and its Impact}

The location of a village i.e., its distance from or access to the local or main markets usually affects agricultural production in so many ways. In order to understand the influence of location on farmers decisions as well as on the selection of areas for programme activities within each district, villages were classified into two: near to the main road and far from the main road, as defined earlier. The results of this analysis are presented in Table II.13. It is clear that the results do not reveal major differences between the locations for most of the variables measured. There are no significant differences in agricultural production, health. livelihood and incomes between the villages. This suggests that proximity to the main road does not necessarily mean access to market, technology and service in (ihor. Villages nearer to roads are equally badly endowed with basic infrastructure as those located farthest. In other words, the poor, road condition and the lack of adequate transportation services neutralise the location effect. On this account, it can be suggested that the selection of villages for programme implementation will not be biased hy location. 
Table II. 13. Location and its Impact on Economic Activities

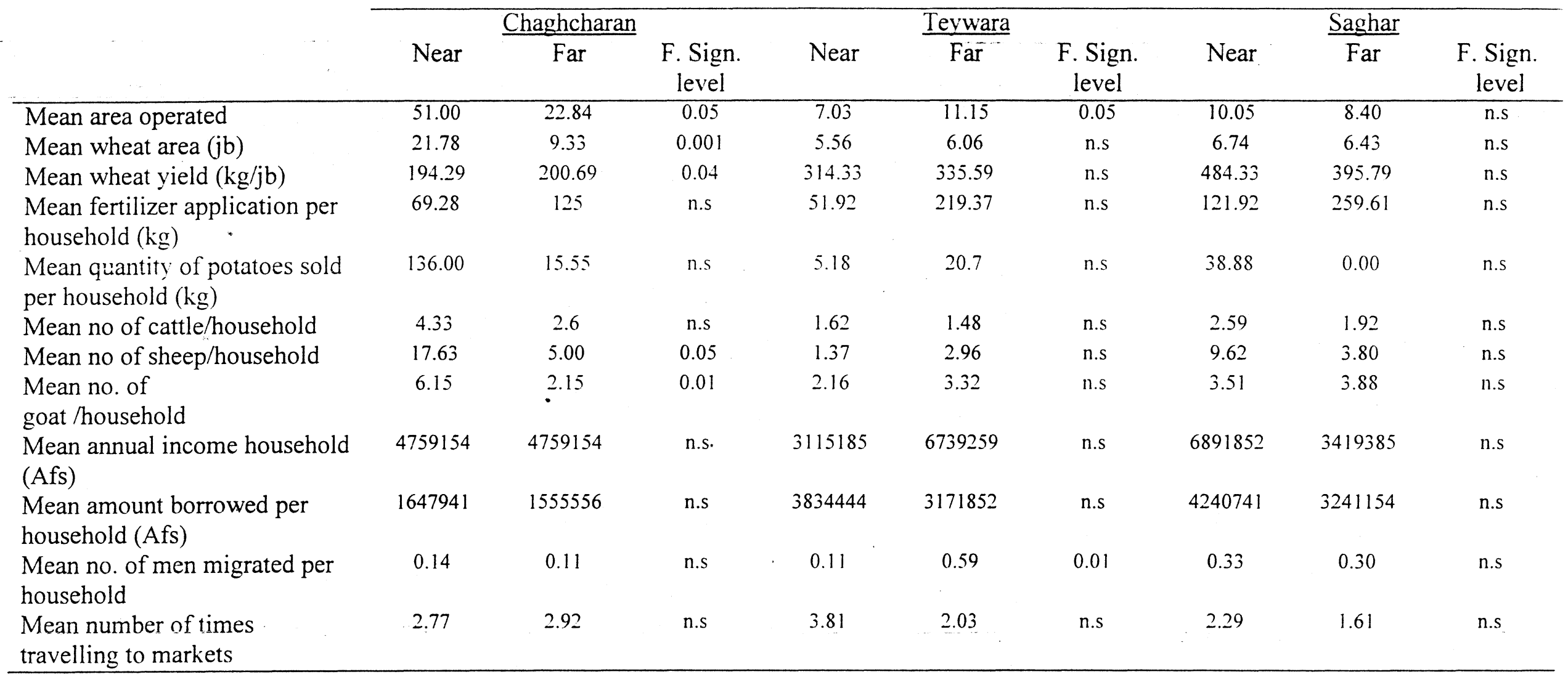




\subsubsection{Livelihood Security}

Iable 11.14 suggests that the number of refuges during the war with the Sovied l'nion and later during the Mujahiddin era was very low in Saghar. though almost half of those who migrated are still relugecs. It was exceptionally high in (haghcharam. hut almost all the estimated $64 \%$ of refugee lamilies have now returned to their villages.

A WTP report (1997) indicates that the province is self-sufficient in wheat. but the surve! tcam has witnessed many pockets of food deficit villages, arising from either poor harvest and $/$ or distribution failure. At the time of the survey, farmers in Chaghcharn reported crop failure caused by heavy rain and snowfall during the months of lichruary and March. Malnutrition is also apparent. particularly amongst children bet it tends to be milder.

lable II. 14. Livelihood Security

\begin{tabular}{|c|c|c|c|}
\hline & Chaghcharan & Saghar & Te!war: \\
\hline Former refugee status $(\%)$ & 63.8 & 39.4 & 57.4 \\
\hline (urrent refugee status $(\%)$ & 2.9 & 16.8 & 5.5 \\
\hline Average male migration per village & 53 & 146 & 73 \\
\hline \multicolumn{4}{|l|}{ When experience food deficit ${ }^{1}$} \\
\hline - Pre-harvest & 100 & 83 & 67 \\
\hline - Winter & 17 & 33 & $\therefore 3$ \\
\hline Main reasons for food deficit ${ }^{1}$ & - & & \\
\hline - Low harvest & 100 & 33 & $3:$ \\
\hline - Lack of land & 33 & 17 & 50 \\
\hline - Lack of water & & 50 & \\
\hline - lack of roads/markets & & 17 & 17 \\
\hline - Insecurity & 17 & & \\
\hline
\end{tabular}

\subsubsection{Off-farm Employment}

Return from agricultural activities is low and inadequate to meet food and cash requirement of farm households. People resort to different coping mechanisms to make it through firm 
whe harvest to the other. One of the most important coping mechanisms is seasonal off-farm employment. Thus, labour migration to Kandahar, Helmand and abroad is a common feature. Young males leave after the harvest and return to their villages after the winter, a period when not much work is available, besides some tailoring, carpeting and blacksmithing and the like. Supplementary income is also sought from the sale of gilim, rug, wool, qurut, siveetroot, wild mushrooms, timber, handicraft products and firewood.

\subsubsection{Health Infrastructure}

There is some basic health infrastructure in the sampled districts. However, the service tends to disappear outside the district centres. Table II.15 provides a summary of the key health service indicators. Chaghcharan is the only district in the province with a 50 bed general hospital, which is frequented by villagers from neighbouring districts. It has OPI), pharmacy. dental, dressing, and a vaccination centre. It has no antenatal and postnatal unit, and no laboratory and blood transfusion facilities. The water supply system and flash latrines inside the hospital are not functioning either. The hospital has two male doctors. one dentist. one vaccinator, one anaesthesia nurse and eight other auxiliary staff.

UNICEF has carried out, through the Ministry of Public Health, immunisation programmes in Saghar and Teywara, while in Chaghcharan the Afghan Red Crescent Society is the only actor in this field. Besides immunisation, ARCS has a clinic in Chaghcharan with OPI)s (male and female), dressing and pharmacy; it also gives health education. One male and one female doctor, one pharmacist, one nurse and two health educators run the clinic.

Chaghcharan has also 8 private pharmacies, mostly run by non-medical persons who, besides selling drugs, give all sorts of injections. Drugs are purchased from Herat.

The other sampled districts have poor access to medical services. There is a single clinic in Saghar district centre with facilities for OPD, pharmacy and vaccination. There are six private pharmacies in the district bazzar, stocked with basic drugs. There are eight health workers working in the clinic; two other female health workers are said to be operating privately. 
Like Saghar, Teywara is also poorly endowed with heath infrastructure. Some two months or so ago, the MOP opened the only health centre in the dist"i.:t. The clinic provides (OPI). pharmacy and vaccination services. There is also a vacciration centre. established by INICEF but operated by the Regional Management Team (MOPI). Ilerat. Two medical doctors, one vaccinator. one pharmacist and two health workers make up the health team in the district. There are also four private chemist shops in the district centre and one other in a village.

The lack of access to medical services is apparent, particularly in Seghar and Teywara districts. The clinics and chemist shops offer only very basic services: the clinics can only do simple operations, like appendicitis and caesarean; for other operations and x-rays, pacients have to go to Herat. Medicines are only available in the clinics and chemist shops in the main bazaars. There are no trained TBAs in the districts, but all the sampled villages have access to quite a few untrained traditional birth attendants.

Table II. 15. Access to Health Infrastructure

\begin{tabular}{lccc} 
& Chaghcharan & Saghar & Teywara \\
\hline istance to nearest clinic $(\mathrm{km})$ & 11 & 20.5 & 16 \\
No. of clinics & 2 & 1 & 1 \\
No. of hospitals & 1 & 0 & 0 \\
No. of doctors & $5(1$ female $)$ & 0 & 5 \\
No. of chemist shops & 8 & & \\
No. of other support staff (vaccinators, & $14(7$ female $)$ & $8(3$ female $)$ & 4 (2 female) \\
nurses, health workers, pharmacists, & & & \\
etc.) & 0 & 0
\end{tabular}

\subsubsection{Education}

Chaghcharan with two schools for boys - one up to grade 9 the other up to grade 12 - is the only district with education infrastructure. Teywara and Saghar have no access to formal education. Many villages surveyed have no schools. There used to be a school for girls in 
Ghaghcharan and Saghar before the war. Under Taliban it is not permissible to send girls to school. The handful of girls who are educated went to the madrassas in Pakistan and Iran. In Sarolang, women reported that Taliban have closed the boy's schools as well and instructed parents to send their children to the madrassas instead. For many families education is becoming a luxury; they can not send their sons even to the madrassas, for they need them to work on the farms. The illiteracy rate is, therefore, very high among the young generation. Education is rare in the generation growing up since the war. It is only the older sons who have received education before the war who could read and write.

\subsubsection{Veterinary Services}

The Dutch Committee for Afghanistan (DCA) is the only NGO providing veterinary services in the districts. It has three clinics in Teywara district centre and two more in two big villages; in Saghar, it has one clinic. None of the sampled villages are. however, included in the DCA veterinary programme. Eight paravets - six in Teywara and two in Saghar - all trained by DC $\Lambda$, run the veterinary clinics in these districts.

\subsubsection{The Position of Women}

The survey also tried to compile information about the position of women in the society and their gender awareness. In each of the sampled villages, questions were put forward to women participating in the group discussions on division of labour in agriculture, livestock, domestic tasks and income generating activities. Data from PR $\Lambda$ and observation in the field clearly indicate that the gender division of labour is essentially the same everywhere in the villages. Generally, men and boys performed all work in the fields. The women helped with weeding, if the fields are near to home. Women and girls milked the animals and processed milk products; they also helped men in storing the harvest. Men marketed agricultural products, grazed/herded livestock, butchered, skinned and sheared the sheep. Men, women and children collected manure, assisted in storing fodder and cared for sick animals. Only in Lahengaran village, Chaghcharan district, a female shepherd has replaced her aged husband as the family's breadwinner. Women and girls did all domestic tasks. with men and boys occasionally collecting firewood and repairing houses. Women spun wool, did headwork, made hats, embroidery and other kinds of income-generating activities. 
. In Sarhohlang and Yakhan villages, Teywara district. women have taken over or are assisting men in what is culturally regarded as "men's activity". This was in response to lack of ablebodied men in the villages. Many men went to Iran and Kandahar. looking for employment and many more were killed four years ago during the conflict between Ilczb-e-Islami and Jamiat Islami and between themselves and the neighbouring villages.

Livestock are the source of wealth, status and food. Numbers, therefore. mean a lot in this traditional society. Those who have animals could spin and sell their wool; those with no animal spin wool for the kutchi nomads and earn 45,000 $\Lambda \mathrm{fs}$. for $4 \mathrm{~kg}$ wool spun. The local retail rate for the same weight of spun wool is $100,000 \Lambda \mathrm{fs}$. Wool spinning is thus another main source of income for women. The women also make carpets and gilims for sale. The carpets and gilims are not good quality though. The carpets are thick and coarse, whereas the Afghan market prefers fine carpets. In addition, the designs and colours of the gilims are not spectacular. Women have a difficult time fetching a worthwhile price from carpets in the competitive Herat market. Locally, in Ghor, there is no market for carpets. and, when demand is there, shopkeepers paid so low prices it often did not cover the cost. On the occasion buyers visited villages, the women, desperate to sell their products. undercut each other prices.

Animal products, except milk and yoghurt often given free to the needy, are sold for cash or exchanged with other products. The women claimed, however, that local prices for animal products are too low to be worthwhile; the animals are also affected by disease so that productivity is low. Selling eggs and chicken is another source of income for women. but the income generated is small - the average ownership is 3 chicks/family. Some women have tried bee keeping but the return is low due to lack of adequate flowers for the bees to feed on: the bees have also to be transported to warmer climate every winter, thus adding burden on the women.

Kitchen gardens, despite their attractiveness to improve lamily nutrition and generate extra income, are not feasible. This is so because water is in short supply in almost all the villages surveyed. Collecting water for the gardens would add to the women's already over-stretched workload. In addition, the women said they did not have land to spare for kitchen gardens. The little land the family works on is used for wheat, upon which it depends for sustenance. 
Pot plant garden, such as tomatoes and peppers might be a possibility as it requires less water and no land, just a windowsill but the idea is akin to the women.

Fruit might have also earned women additional income, but again they could not be adequately watered. In the summer, the rivers dry up and women often walk long distance to fetch water for domestic use. Predictably, therefore, women do not like the idea of growing trees for it meant extra work in their part. This probably explains why people equate "onions" with fruit. Only those households who have access to "large" land and labour grow some fruit trees.

It was quite difficult in places to assess women's needs. The women are not used in expressing their opinions publicly in large groups of mixed ages and to strangers. It is cultural for younger women to keep silent and a few selected and respected older women to do all the talking. As a result, calling young women to the group discussions caused them consternation, embarrassment and confusion. The older women often tried to interrupt or dominate the conversation. Having said this, the women in general could not express their views or develop solution to their problems. In many villages, the women were unsure of what to say. The women in Kootchie-Teywara and Khairank-Saghar in particular had the most difficulty in expressing themselves and developing ideas regarding potential programmes to assist them. Kootchie was very conservative compared to the other villages. and the women there were much more housebound than elsewhere. Much time and paticnce and explanations were necessary to assist the women in assessing and determining their needs. Effort was made to encourage the women to express themselves and decide how hest they might be helped, but this often led to the survey team doing much of the talking and the women the listening. Some women came to the group discussion expecting medical consultation and therefore refused even to answer questions, preferring to launch into a detailed litany of their various ailments. When they realised what the team was up to they retired in disgust.

It is evident though that in those villages where women have encroached into men's traditional duties, besides their domestic responsibilities. they seem to be markedly more outspoken, confident, and clear in expressing their needs and problems. This attitude was witnessed particularly among women who were temporary settlers and who also enjoyed more autonomy in their daily lives. The women of Zargaron and Tatian villages, Saghar 
district, were outspoken and forthright and several women were able to articulate their problems. The women said their worst problem is poverty. Poverty left them unable to feed themselves and their families. and send their children even to the local madrassas. Porerty keft them without adequate clothing and security; it caused conflict between families. forced the men to leave the family in search of work and increased the workload and isolation on them.

Despite some localised differences, the team was given complete and unimhibited aceese to women of all ages and at all times. PRA studies in future should provide more detailed insight about the position of the women in the society. 
PART III. HOUSEHOLD CHARACTERISTICS

Parts III to VIII present information gleaned from the household survey. Household is a very important unit of study, especially in Afghanistan where other social institutions and forums are defunct. Shared resources and income means that most decisions are made in the household, by the household. Within the household, forces of demand and supply are at work and can be observed to give insight into how best to improve the larger economic situation.

\subsection{Household Size and Structure}

Household size and structure can have a significant effect on production and consumption pattern. This is more likely to be the case in a subsistence economy, where consumption needs and the volume of economic activity are related to the labour available in the household. Table III.1 presents cross-sectional data for the case-districts.

Table III.1. Mean Household Size in the Case-Districts

\begin{tabular}{|c|c|c|c|c|c|c|}
\hline \multirow[b]{2}{*}{ District } & \multirow{2}{*}{$\begin{array}{l}\text { Overall } \\
\text { Mean }\end{array}$} & \multicolumn{4}{|c|}{ Household Size } & \multirow{2}{*}{$\begin{array}{l}\text { F. sign } \\
\text { level }\end{array}$} \\
\hline & & $2-5$ & $6-9$ & $10-13$ & $>13$ & \\
\hline Chaghcharan & 10.06 & 4.55 & 7.23 & 10.94 & 18.46 & 0.000 \\
\hline Saghar & 9.43 & 3.38 & 7.2 & 10.88 & 17.22 & 0.000 \\
\hline Teywara & 7.67 & 3.78 & 7.82 & 10.86 & 16.6 & 0.000 \\
\hline F.sign. level & 0.05 & & & & & \\
\hline
\end{tabular}

The mean household size in Chaghcharan stands at about 10 persons per household, compared to 9 in Saghar and 8 in Teywara. It seems that extended family groups of two or more generations live in the same household, particularly in Chaghcharan. The F-test suggests that there is significant difference in the distribution of persons between household groups in all the districts. The same test, when applied to the three sample districts, shows that there is also significant variation (alpha $=0.05)$ between the districts.

In Table III. 2 we show the mean labour force available to a houschold. The pattern, as apparent from the table, is that larger households have larger labour force. The average 
number of workers per household is around 5. Again, the F-test shows that the difference between household size categories is signilicant in all the districts. However, the difference between the districts is not significant statistically.

Table III.2. Mean Labour Force ( $>14$ years) per Household

\begin{tabular}{lcccccc}
\hline & Overall & \multicolumn{4}{c}{ Household Size } & F. sign \\
\cline { 3 - 6 } District & Mean & $\mathbf{2 - 5}$ & $\mathbf{6 - 9}$ & $\mathbf{1 0 - 1 3}$ & $>\mathbf{1 3}$ & Level \\
\hline Chaghcharan & 5.19 & 2.36 & 3.68 & 6.12 & 9 & 0.000 \\
Saghar & 5.0 & 2.62 & 3.95 & 5.88 & 7.89 & 0.000 \\
Teywara & 4.17 & 2.28 & 4.05 & 5.71 & 9.4 & 0.000 \\
F.sign. level & N.S. & & & & & \\
\hline
\end{tabular}

Note: N.S. means statistically not significant

The result of the cropped area analysis is presented in Table III.3. As wheat is the single most important food crop cultivated, it was deemed a reasonable measure of cropped area. The average wheat area cultivated is around 16 jeribs in Chaghcharan. 9 in Saghar and 6 in Teywara. Landholdings are relatively larger in Chaghcharan than in Saghar and Teywara. This explains, in part, the high level of wheat area in Chaghcharan.

Table III.3. Area Cropped with Wheat by Household Size (in jerib)

\begin{tabular}{lcccccc|}
\hline & Overall & \multicolumn{3}{c}{ Household Size } & \multicolumn{1}{c|}{ F. sign } \\
\cline { 3 - 6 } District & Mean & $\mathbf{2 - 5}$ & $\mathbf{6 - 9}$ & $\mathbf{1 0 - 1 3}$ & $>\mathbf{1 3}$ & Level \\
\hline Chaghcharan & 16.36 & $\mathbf{8 . 0 5}$ & 14.93 & 15.53 & 26.85 & 0.000 \\
Saghar & 9.43 & 3.69 & 4.33 & 5 & 11.30 & N.S. \\
Teyivara & 6.04 & 3.44 & 6.04 & 7.64 & 8.35 & N.S. \\
F. sign.level & 0.000 & & & & & \\
\hline
\end{tabular}

As we see from the cross-sectional data, a relationship exists between houschold size and cropped area. The variation in cropped area between household sizes is more apparent and statistically' significant in Chaghcharan than in the other two districts. It is also significant between the districts. The area cultivated is related to the cuantity of labour available in the houschold. The independent variable, household size. works in two ways: a large household means more hands available for work, thus enabling the houschold to 
farm large tracts of land; but it also means more mouths to feec' which forces the household to grow more wheat, either extensively or intensively, for sustenance.

\subsection{Farm Irrigation Status and its Distribution}

Irrigation status is an important factor governing farm productivity. In an area with a patchy irrigation infrastructure, cultivating the land demands a lot of work and labour time. In Table III.4 we look at the distribution of irrigated and rainfed land among household categories and also establish how important household size is in determining the area operated. The result shows that household size is not significantly correlated with irrigation status; that is, a large household does not necessarily mean increased area operated, either irrigated or rainfed.

The average area operated by a household in Saghar and Teywara is 4 to 5 jeribs of irrigated land; the rainfed area operated is also about the same size. In Chaghcharan. on the other hand, the average land operated is 17 to 18 jeribs per irrigation category. This is in line with the larger size of landholding in Chaghcharan, mirrored by the higher mean within each household size group and an overall maximum value of 160 jeribs of irrigated land for a household.

Table III.4. Mean Area Operated by Household Size and Irrigation Status

\begin{tabular}{|c|c|c|c|c|c|c|}
\hline & \multicolumn{6}{|c|}{ Rainfed } \\
\hline & \multicolumn{4}{|c|}{ Household Size } & \multirow[t]{2}{*}{ Mean } & \multirow[t]{2}{*}{ Max } \\
\hline & $2-5$ & $6-9$ & $10-13$ & $>13$ & & \\
\hline Chaghcharan & 10 & 17.32 & 14.62 & 32.69 & 18.69 & 100 \\
\hline Saghar & 1.12 & 2.6 & 7.88 & 3.89 & 4.19 & 40 \\
\hline Teywara & 2.22 & 7.64 & 3.71 & 5.8 & 5.06 & 20 \\
\hline
\end{tabular}

\begin{tabular}{|c|c|c|c|c|c|c|c|}
\hline & \multicolumn{6}{|c|}{ Irrigated } & \multirow{3}{*}{$\begin{array}{l}\text { F. sign } \\
\text { level }\end{array}$} \\
\hline & \multicolumn{4}{|c|}{ Household Size } & \multirow[t]{2}{*}{ Mean } & \multirow[t]{2}{*}{ Max } & \\
\hline & $2-5$ & $6-9$ & $10-13$ & $>13$ & & & \\
\hline Chaghcharan & 9.09 & 9.23 & 10.31 & 43.92 & 16.76 & 160 & 0.000 \\
\hline Saghar & 4.88 & 4.26 & 6.95 & 3.61 & 5.06 & 50 & n1.s. \\
\hline Teywara & 3.26 & 3 & 5.89 & 5.6 & 3.73 & 20.5 & 0.05 \\
\hline
\end{tabular}


The F-test for Chaghcharan suggests highly significant variation between household groups, while in Saghar the test result is not significant. In Teywara, the difference hetween household groups is significant at alpha 0.05 level.

\subsection{Land Tenure}

The system of land tenure is a mixture of private ownership and sharecropping, and has remained unchanged over the years. The proportion of landless households is very small. Table III.5 shows the proportion of area operated by houscholds according to land tenure. In Chaghcharan and Saghar, owners make up over two-thirds of the total households and cultivate a correspondingly high proportion of land. In Teywara where owners constitute 64 percent of the households we see them operating only half of the land. There is no marked difference in the area operated by owner-cum-sharecroppers of the three districts. Sharecroppers account for the lowest area operated in Saghar district, despite constituting 4 percent of the sample households. With this exception, the percentage of land operated by tenure groups is distributed according to the percentage of households constituted. with sharecroppers operating the lowest percentage of land in all the districts.

Table III.5. Percentage Distribution of Total Area Operated by Farm Status

\begin{tabular}{lcccccc}
\hline & \multicolumn{2}{c}{ Owners } & \multicolumn{3}{c}{ Owner-cum-Sharecropper } & Sharecropper \\
District & Area & Ilouseholds & Area & Households & Area & Households \\
\hline Chaghcharan & 71.0 & 74.2 & 26.6 & 21.0 & 2.5 & 4.8 \\
Saghar & 68.0 & 67.9 & 31.4 & 28.3 & 0.6 & 3.8 \\
Teywara & 51.3 & 63.5 & 30.6 & 25.0 & 18.0 & 11.5 \\
\hline
\end{tabular}

Tenancy arrangements are, by and large, the same in all the districts. As discussed carlier (Part II, 2.2.3), all investments made on crops, such as fertilizer, seed and oxen are all borne by the landlord as part of the contract. The farmer gives nis labour. The output is split between the landlord and the farmer in the ratio of $3: 1$. This is hardly an equitable distribution, considering that costly inputs from the landlord are the exception rather than the rule. His claim to three-fourth of the output is based on ownership of the land, and the sharecropper is left with little output to show for his effort. The sharecropper could increase his output through more efficient cropping patterns, leading to an increase in overall yicld 
without incurring any additional cost, but it would mean a more productive use of his input, lahour.

\subsection{Land Status and Productivity Compared}

Irrigated land is not scarce in the case-districts and farmers have to rely on precipitation to feed of their crops. This inevitably leads to differences in yield between the two types of land. irrigated and rainfed. Taking wheat yield as a yardstick, efficiency is measured in Table III.6. $\Lambda$ glance at the table show's that the mean yield per jerib is significantly high from irrigated land. In Saghar, although the mean is $180 \mathrm{~kg} / \mathrm{j}$ for rainfed land and $334 \mathrm{~kg} / \mathrm{j}$ for irrigated land. statistical tests do not reveal significant variation between the two samples. This is because of the relatively high precipitation in this valley, which increases the productivity of rainfed land. This, however, does not detract from the overall finding that wheat yield is directly linked to land status.

Table III.6. Mean Wheat Yield per Jerib by Land Status $(\mathrm{kg})$.

\begin{tabular}{lllll}
\hline District & Overall Mean & Mean Rainfed & Mean Irrigated & F.sign. level \\
\hline Chaghcharan & 147.52 & 91.3 & 203.75 & 0.000 \\
Saghar & 257.07 & 179.63 & 334.50 & N.S. \\
Teywara & 186.52 & 130.85 & 242.20 & 0.000 \\
F.sign. level & N.S. & & & \\
\hline
\end{tabular}




\subsection{Cropping Pattern}

The cropping pattern does not show a marked difference. both between and within the districts surveyed. Table IV.1 provides information on the proportion of land allocated to various crops, fruit and vegetable. It also indicates, albeit indirectly, the intensity of land use in the case-districts.

It is noticeable that wheat is by far the most important crop grown. $\Lambda$ s a proportion of the total area cropped in a season, wheat area accounts for 71 percent in Saghar, 69 percent in Teywara and 47 percent in Chaghcharan. Wheat area in Chaghcharan is high, because the average land holding there is relatively high (see Part III, Table III.3) so that households do not have to cultivate all of it to produce enough wheat.

Following wheat, barley is the second most important food crop. Barley area accounts for 4 percent in Chaghcharan and just under 1 percent in Saghar. Besides food, barley is also used to feed animals, and this explains, in part, why it is a lesser-valued crop.

Maize is planted immediately after spring wheat or barley, but farmers do not seem to value it for its food. Despite being the second cereal crop in Afghanistan, maize in Ghor occupies a tiny proportion of the area cropped in a seașon. It is in fact not planted at all in Chaghcharan district. Maize, because of its short growing season, could have helped ease the food shertage in the lean months.

Besides the cereals, farmers also grow potatoes, both for food and sale. Potatoes occupy relatively more land in Chaghcharan district, just over 2 percent. Potato acts as an insurance crop for subsistence, as it can be stored for quite some time without losing its food value and taste. It is planted in April/May, again in competition for land with spring wheat and barley.

Relative to the area occupied by the "fill-in" crops of barley and maize. fruit and vegetables account for more land in Saghar. A fraction of land is also allocated to fruit and vegetables in Teywara. but none at all in Chaghcharan. Apricot, walnut, apples are the main fruit varieties grown in Teywara and Saghar. 
Table IV.1. Allocation of $\Lambda$ gricultural Land (percentage cropped area)

\begin{tabular}{lccc}
\hline Crop & Chaghcharan & Saghar & Teywara \\
\hline Wheat & 46.6 & 71.3 & 68.7 \\
Maize & 0 & 1.3 & 1.0 \\
Barley & 4.3 & 0.6 & 2.1 \\
Potato & 2.3 & 0.9 & 1.7 \\
Vegetable & 0 & 1.7 & 0.1 \\
Fruit & 0 & 1.6 & 0.4 \\
Alfalfa & 1.2 & 0 & 1.1 \\
Clover & 0.8 & 0.1 & 0.2 \\
Non-fruit trees & 0.5 & 0.1 & 0.1 \\
Total & 55.7 & 77.6 & 75.4 \\
\hline
\end{tabular}

Fodder crops of alfalfa and clover are cropped on large area in Chaghcharan, because people there have larger holdings and more animals as well. Besides feed, these crops improve soil productivity and hence output by fixing nitrogen in the soil, especially when used in rotation with cereals.

The non-fruit tree are mainly willows and poplar, grown in the riverbanks and around irrigation ditches. Willows are used for fuel, and poplar for construction purposes. Thesc trees occupy land for quite some time, up to ten years if allowed to mature. Again, slightly larger percentage of land is allocated for non-fruit trees in Chaghcharan.

Overall, the intensity of land use is much higher in Saghar and Teywara than in Chaghcharan. Just over three-fourth of the land is intensively used in a season in Saghar and Teywara as opposed to about half in Chaghcharan. The implication of this is that where land holding is small, as in the case of Saghar and Teywara, households use it more intensively throughout the year.

\subsection{Variation in the Cropping Pattern by Farm Size}

(ihor is a subsistence economy. Production is driven not by market forces but by household consumption need. Table IV.2 shows the different crops planted by farm size. 
The data suggest that wheat is more important for smaller farmers. hough large farmers also allocate much of their land to this staple crop. Barley and otato are also grown as secondary crop, but mostly by the "middle" size farm groups. In Saghar. maize is faroured by the small farmers: potatoes are also cultivated as a cash-cum-suhsistence crop. In Teywara, potatoes are grown but little maize, that too in the medium size farms.

Table IV.2. Variation in (ropping Pattern between Farm Sizes (in percent)

\begin{tabular}{lcccc}
\hline $\begin{array}{l}\text { Chaghcharan } \\
\text { Farm Size }\end{array}$ & $\mathrm{N}$ & Wheat & Barley & Potato \\
\hline $0-6$ & 10 & 61.0 & 0 & 6.5 \\
$6.1-20$ & 22 & 67.7 & 6.2 & 8.0 \\
$20.1-60$ & 20 & 53.4 & 6.5 & 1.2 \\
$>60$ & 9 & 34.5 & 2.5 & 1.4 \\
\hline
\end{tabular}

\begin{tabular}{lccccc}
\hline Saghar & & & & & \\
Farm Size & $\mathrm{N}$ & Wheat & Maize & Potato & Fruit \& Veg \\
\hline $0-2$ & 10 & 81.7 & 10 & 10 & 0 \\
$2.1-10$ & 29 & 68.8 & 2.5 & 2.5 & 3.2 \\
$10.1-20$ & 9 & 69.5 & 0.5 & 0.1 & 3.0 \\
$=20$ & 5 & 77.5 & 0 & 0.1 & 2.1 \\
\hline Teywara & & & & & \\
Farm Size & $\mathrm{N}$ & Wheat & Maize & Potato & \\
\hline $0-2$ & 15 & 68.7 & 0 & 2.8 & \\
$2.1-10$ & 17 & 73.4 & 0.4 & 2.5 & \\
$10.1-20$ & 13 & 77.3 & 1.6 & 1.0 & \\
$=20$ & 7 & 61.6 & 1.0 & 1.4 & \\
\hline
\end{tabular}

Note: "N" means number of observation in each category

\subsection{Crop Rotation}

Various cropping patterns are practiced in the case-districts. Wheat. the staple crop everywhere. is rotated with other crops, depending on the extent of pressure on land and the availability of irrigation water. The same farmer would practice a different crop 
rotation pattern on his irrigated land, and another pattern on his rainfed land, thus making the whole situation quite complex! Furthermore, the crop rotations themselves might be quite complicated, for example wheat $>$ barley $>$ potato $>$ wheat. $\Lambda$ list of the various crop rotations follows:

- wheat $>$ fallow $>$ wheat

- $\quad$ wheat $>$ vegetable $>$ wheat

- $\quad$ wheat $>$ fallow $>$ barley

- wheat $>$ barley $>$ potato $>$ wheat

- $\quad$ wheat $>$ potato $>$ barley $>$ wheat

- $\quad$ wheat $>$ barley $>$ wheat

- wheat $>$ potato $>$ wheat

- wheat $>$ clover $>$ maize $>$ wheat

- barley $>$ potato $>$ wheat

- barley $>$ fallow $>$ barley

The most common practice involves farmers growing wheat and then let the land fallow. After this, they again grow wheat on this same land. This of course is not an efficient way of utilising land, especially in such a low-income area where any additional income from other crops would be well received. In many areas, even this fallow period is eliminated and farmers grow wheat continuously on their land with the consequent impact on productivity.

The crop rotation patterns above are seen mostly on irrigated land, as most rainfed land is planted solely with wheat. Thus, we would see cropping patterns like wheat $>$ wheat or wheat $>$ fallow $>$ wheat. Since wheat requires less water ( 4 to 5 cycles a year), as compared to other crops like potato and barley, it is most suited for cropping on rainfed land. For this reason, other crops cannot be rotated with wheat when grown on land with no irrigation water.

\subsection{Intercropping}

Intercropping is not practiced in any of the sampled districts. Nlthough this is a proven method of maximizing return from small unit of land, farmers have their own reasons for not opting for this technique. When questioned, they cited the unfavorable climate as the 
main reason. Lack of know-how is another factor. Farmers u.ce trial-and-error methods to cultivate the land. Some farmers tried intercropping fruit trees. but the trees did not survive. Small farmers are not in a position to take risks with their crop, and prefer to stick to traditional methods even if it meant smaller return from the land.

\subsection{The Management of Staples}

\subsubsection{Labour Use}

Figure IV.1. presents labour use by activity in the three districts. The data are for area cropped with wheat. Family labour, both male and female, and hired labour are summed up and presented in man-days per jerib.

In Saghar, land preparation takes longer than in the other two districts. This is because of the uneven terrain which poses a problem for planting. Land preparation involves lirst breaking up the soil; this is done twice with the help of oxen. Then, seeds are sown and covered with soil. This too is done with a help of oxen, once for winter wheat and once for spring wheat. Weeding also takes up much of the time, an average of 3 man-days, with the weed used for animal feed. Watcring takes less time in Chaghcharan as compared to Saghar and Teywara, as the land in Chaghcharan allows the water to run freely. In contrast to this, the soil in the other two districts is sandy and absorbs more water. Harvesting is done by hand and threshing is left to local devices in which the harvested wheat is spread on the ground and is systematically trampled by oxen and people.

The lack of labour-saving machinery explains the excessive time input per jerib. The only help to the farmer is in the form of oxen. The final stages of cropping like milling, bagging and marketing take up very little time. Much of the crop is for home consumption; whatever meager surplus is left would be sold locally.

The contribution of women to the overall process is minimal. as can be seen from Figure IV.2. The males in the family do most of the agricultural work. If, on rare occasions. extra labour is needed, men might be hired and only a tiny proportion of the work is attributed to the female in the household. This claim is debatable. however, as women 
.were seen working in the fields and much of the work is also done inside the house. It is possible that tribal custom and male pride encourage the men to claim much of the credit for work done. while playing down the role of the women. In any case, a large proportion of work done by women is 'invisible' and goes unacknowledged.

\subsubsection{Crop Calendar}

In all the three case-districts. the winter wheat is sown mainly in October, and remains under the soil for five months. It may either germinate or end up rotting, depending upon the severity of the winter. Spring wheat is sown in March or April. In Teywara, 100 percent of the respondents said they planted wheat last season in October against 67 percent in Chaghcharan and 80 percent in Saghar. In the latter two districts, some farmers start land preparation as early as in September. Weeding continues from late March to June. Ilarvesting is in July, or the latest in September. Figure IV.3 depicts the cropping calendar for each district.

Barley is planted at the same time as spring wheat and harvested late, in September or October. Potatoes are also grown in all the districts, with land preparation and sowing carried out in $A$ pril and May. After this weeding must be done, at least thrice, until September or ( )etober. with harvesting in the following month.

Nurseries are established in $\Lambda$ pril, budding and grafting takes place between July and September. Vegetables are not common. owing to land and water shortage. Women maintain "kitchen gardens". primarily for domestic consumption. Other vegetable calendars can be read from the figure.

\subsubsection{Seasonality of Labour Demand and Wages}

In an agricultural economy. all variables must rise and fall in response to the demands of the agricultural cycle. Because activities are concentrated around a particular time of the year. we would expect a corresponding increase in labour demand during that time. There are three periods of heavy activity - land preparation, planting and harvesting. Figure IV .4 presents the variability in farm lahour wage rates. Wage rates are highest from $A$ pril to ()ctober in (haghcharan and Saghar. in Teywara they peak between June and October. Wages then fall dramatically from November until the next peak season. 
Figure IV. 3 Crop Calendar

A) Wheat (Winter) calendar
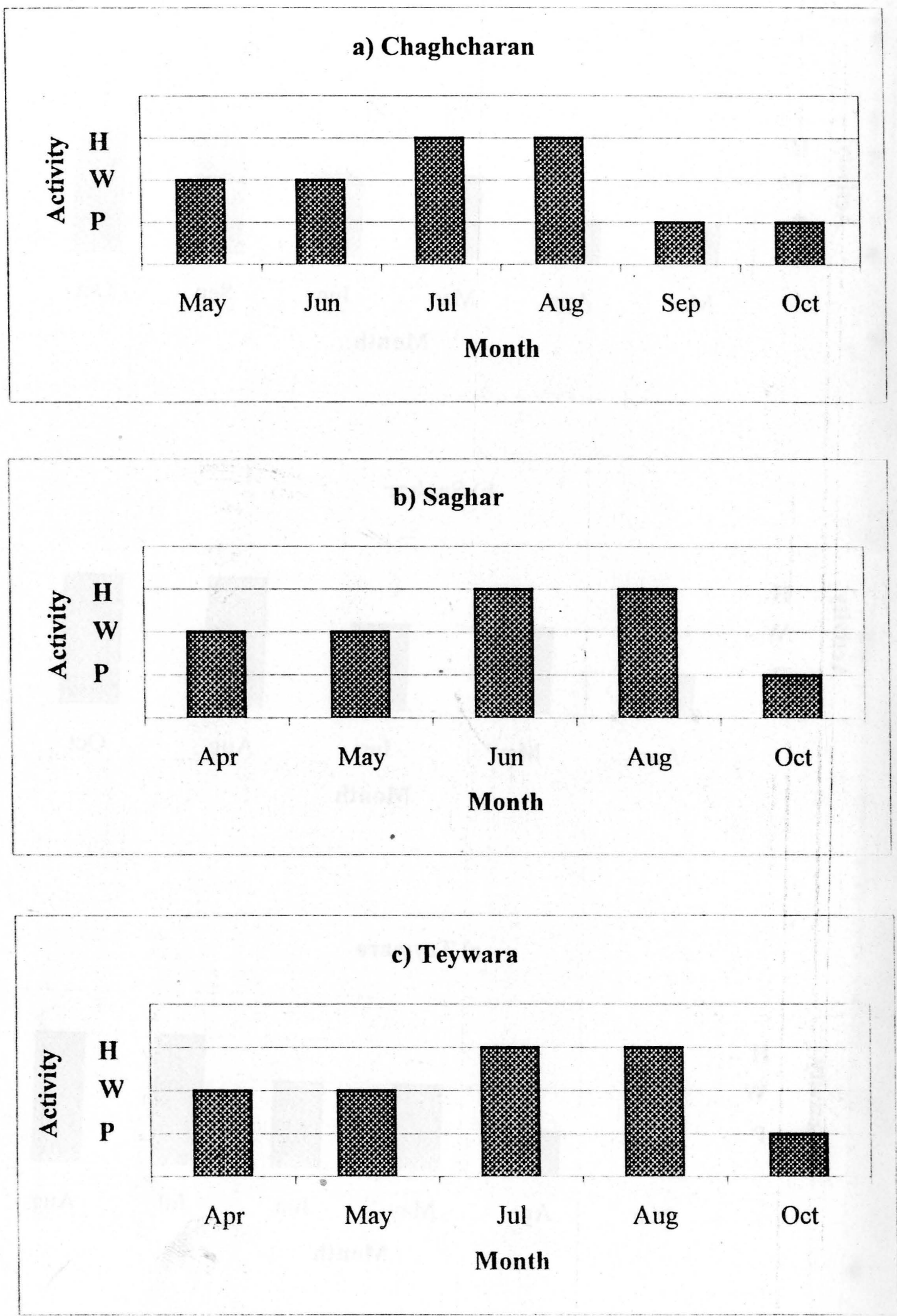

$\mathrm{P}=$ Preparation and Planting, $\mathrm{W}=$ Weeding, $\mathrm{H}=$ Harvesting 
B) Wheat (Spring) calendar
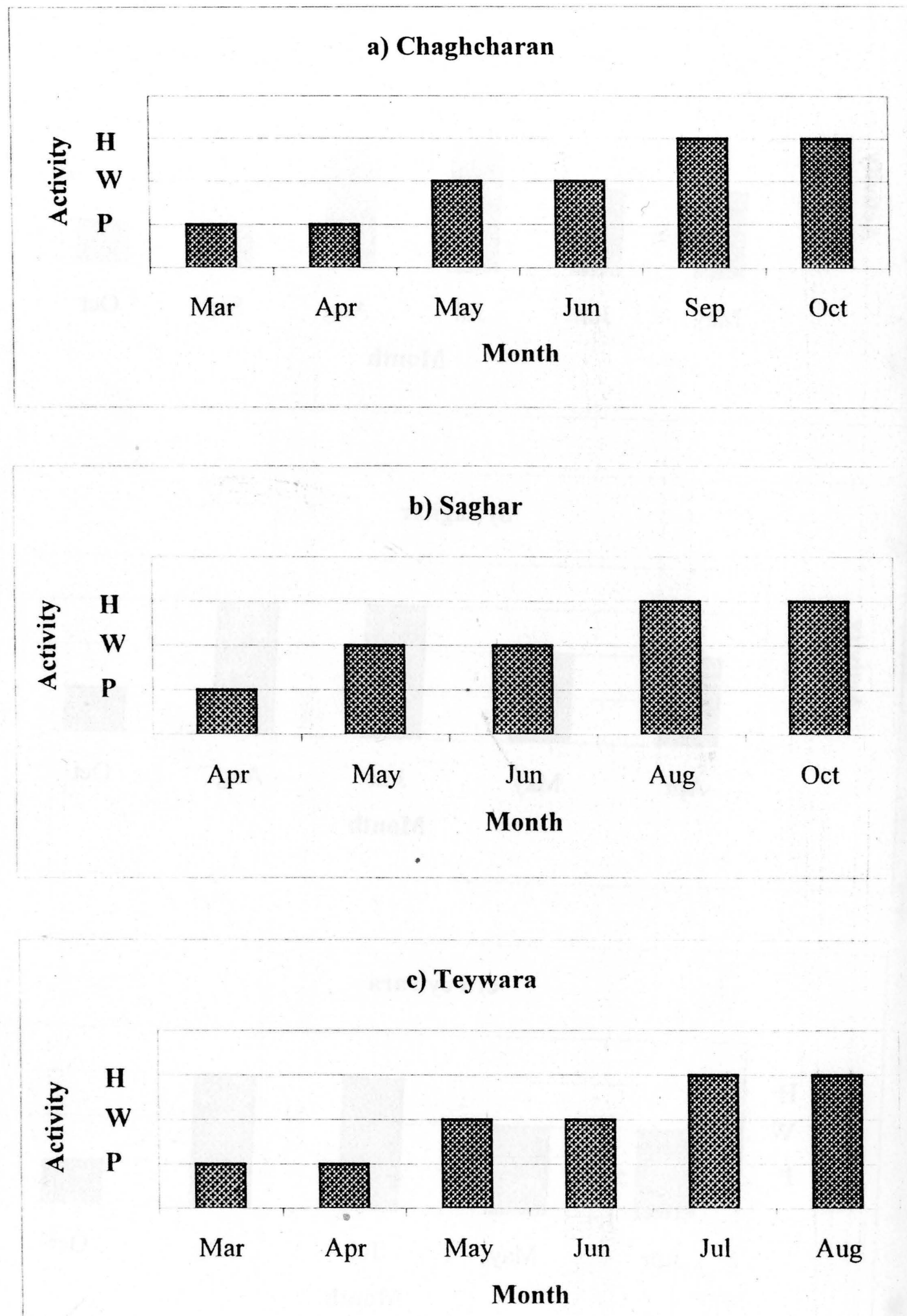

$\mathrm{P}=$ Preparation and Planting, $\mathrm{W}=$ Weeding, $\mathrm{H}=$ Harvesting 
C) Barley calendar

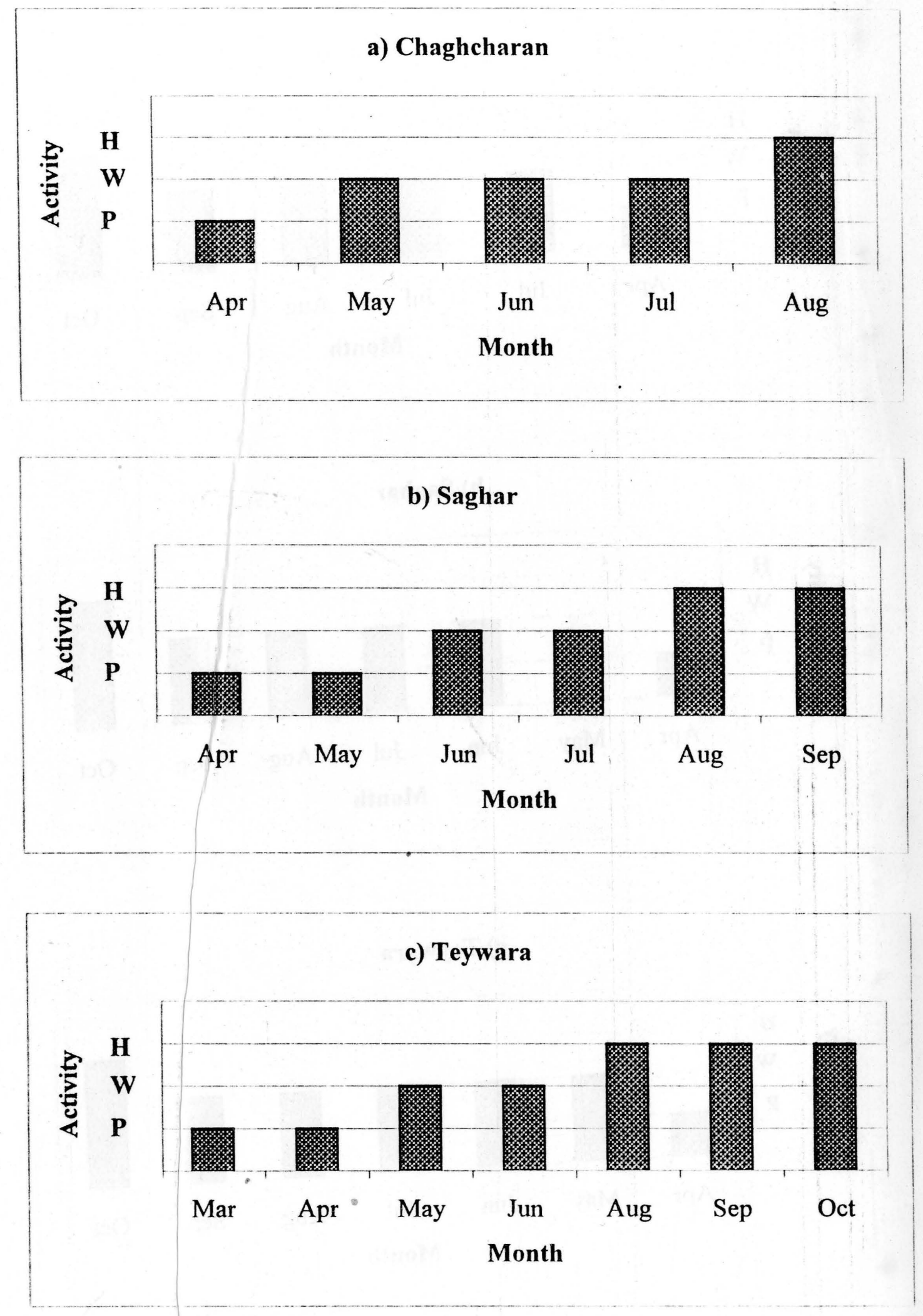

$\mathrm{P}=$ Preparation and Planting, $\mathrm{W}=$ Weeding, $\mathrm{H}=$ Harvesting 
D) Potato calendar

a) Chaghcharan

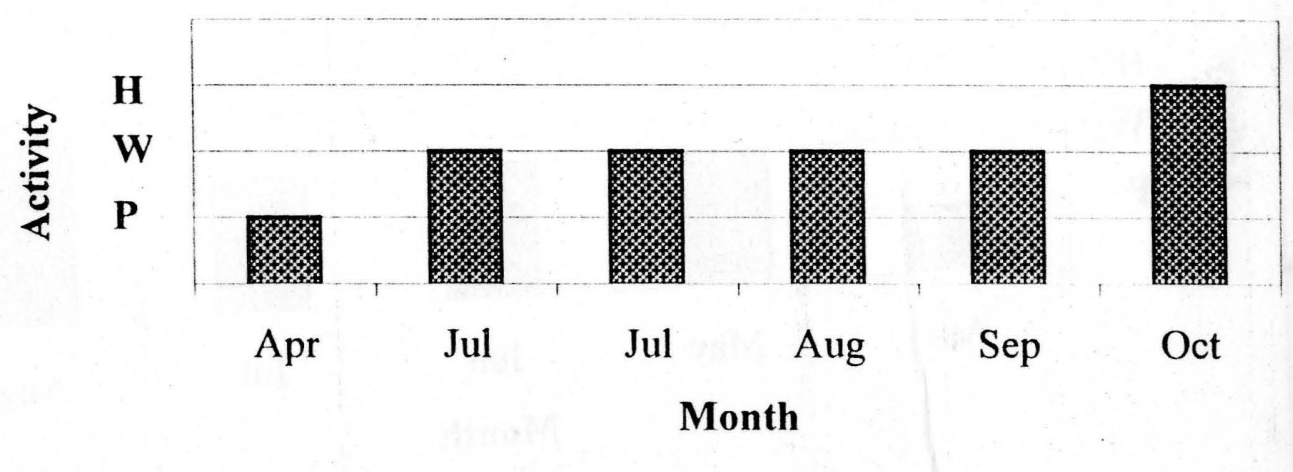

b) Saghar

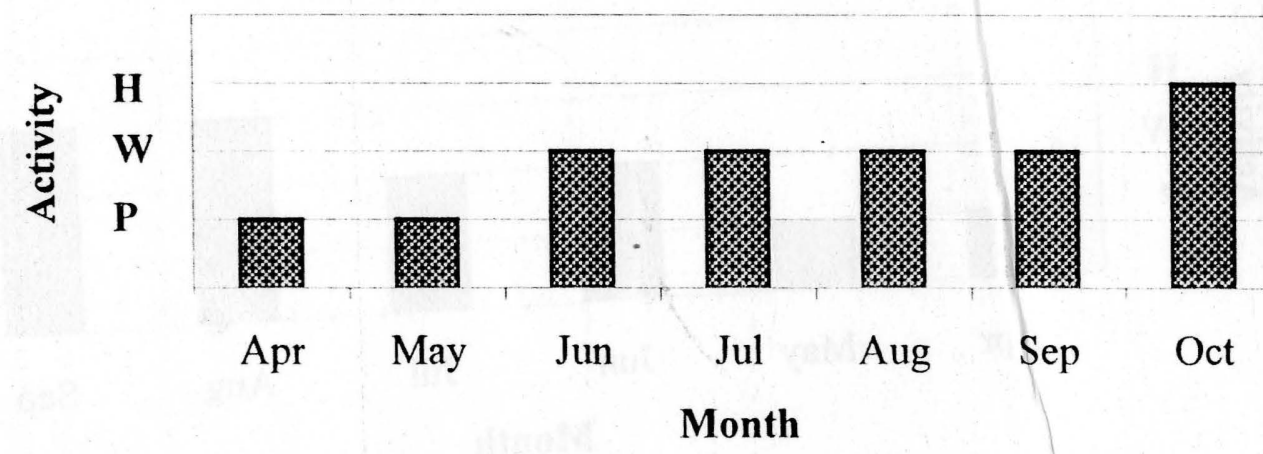

c) Teywara

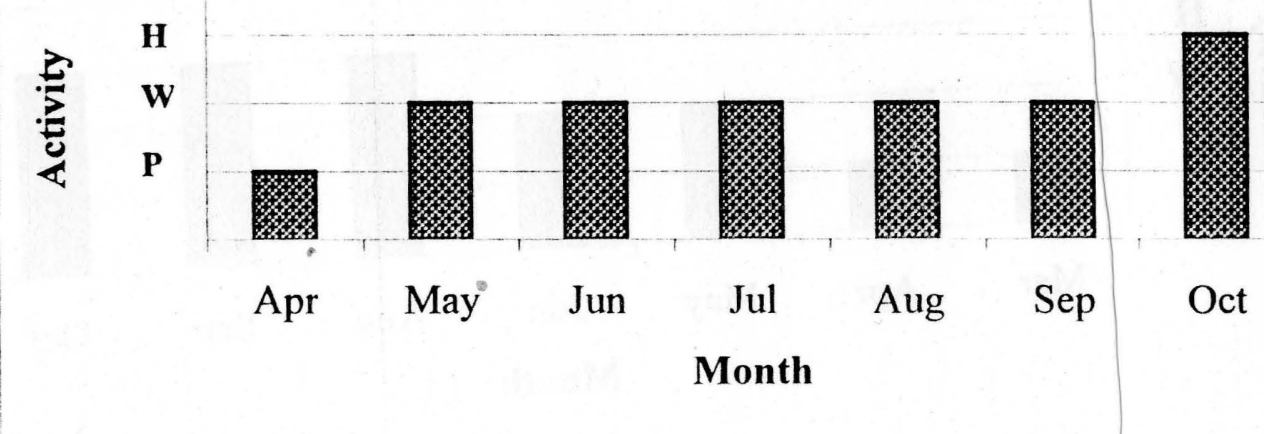

$\mathrm{P}=$ Preparation and Planting, $\mathrm{W}=$ Weeding, $\mathrm{H}=$ Harvesting 
E) Alfalfa calendar
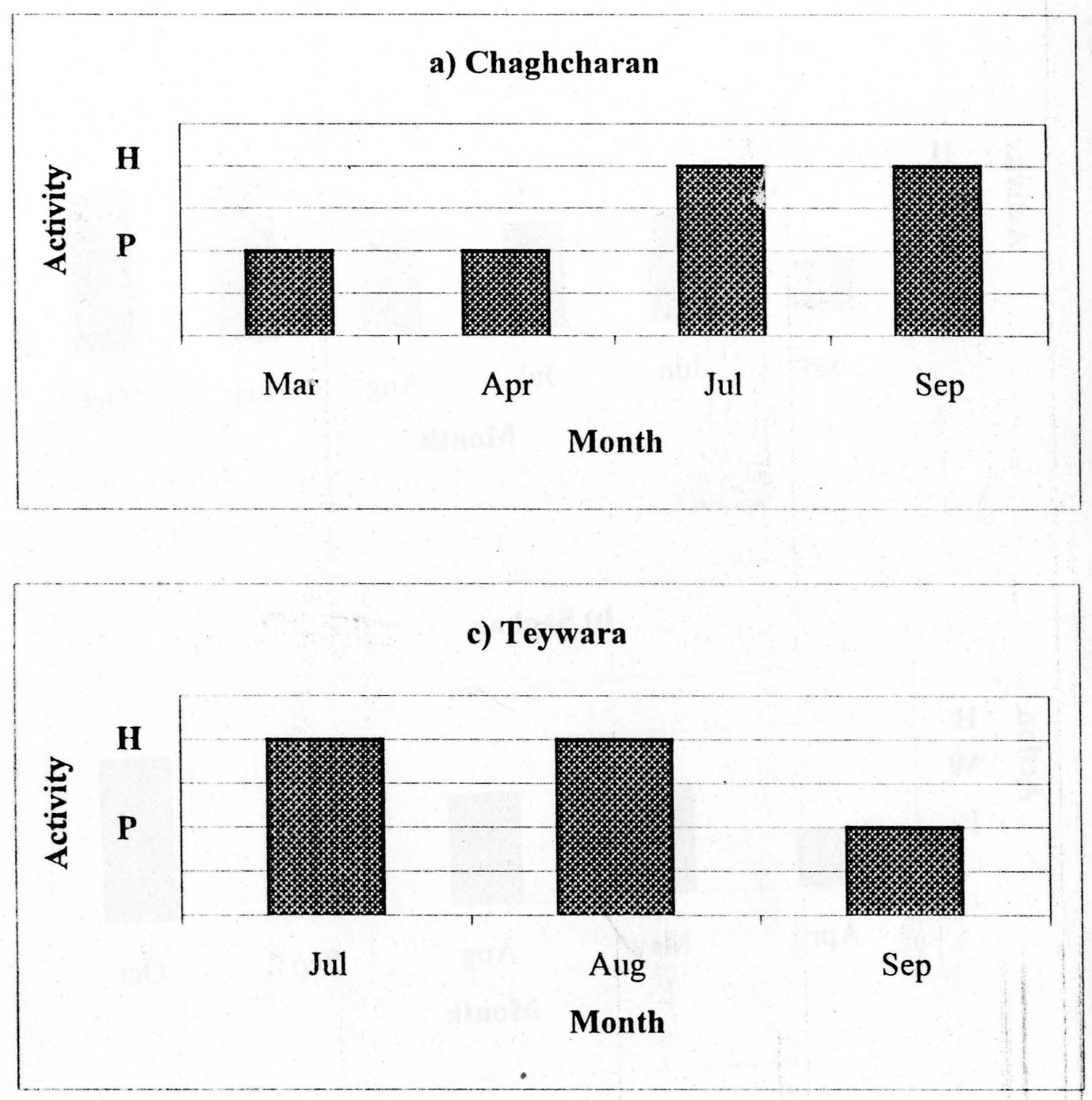

$\mathrm{P}=$ Preparation and Planting, $\mathrm{W}=$ Weeding, $\mathrm{H}=$ Harvesting 
F) Onion Calendar

a) Chaghcharan

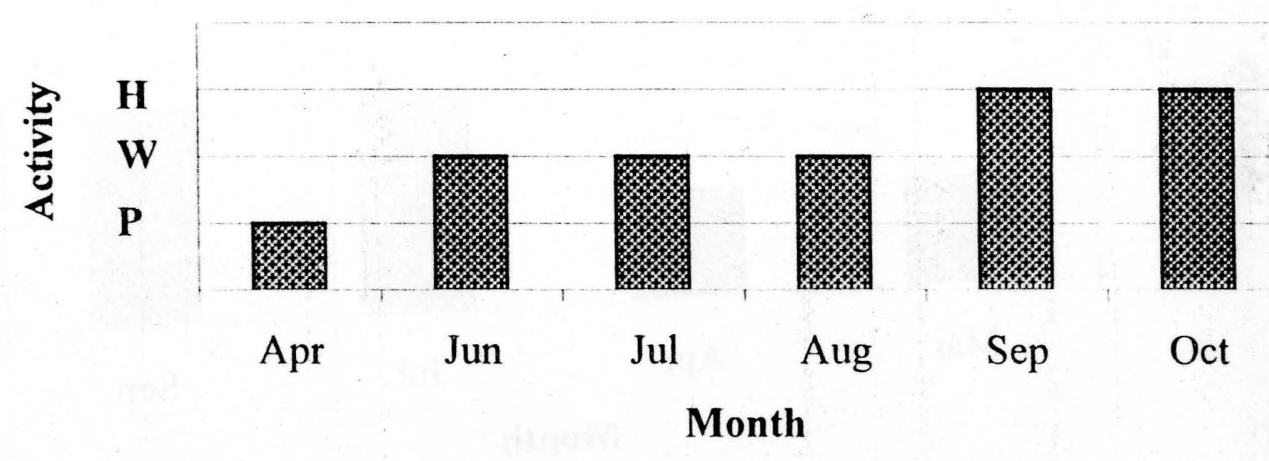

b) Saghar
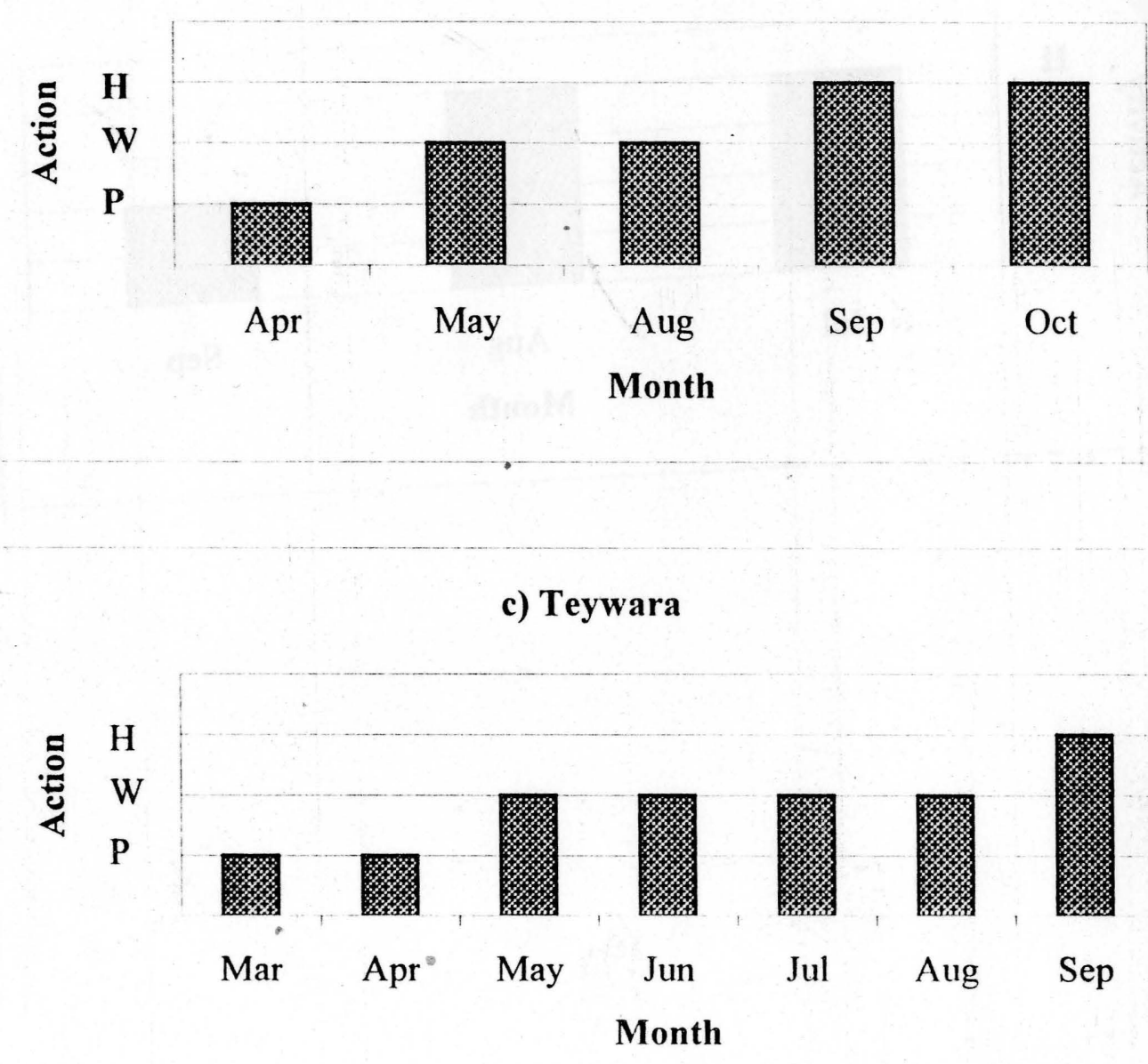

$\mathrm{P}=$ Preparation and Planting, $\mathrm{W}=$ Weeding, $\mathrm{H}=$ Harvesting 
G) Apple/ Apricot calendar
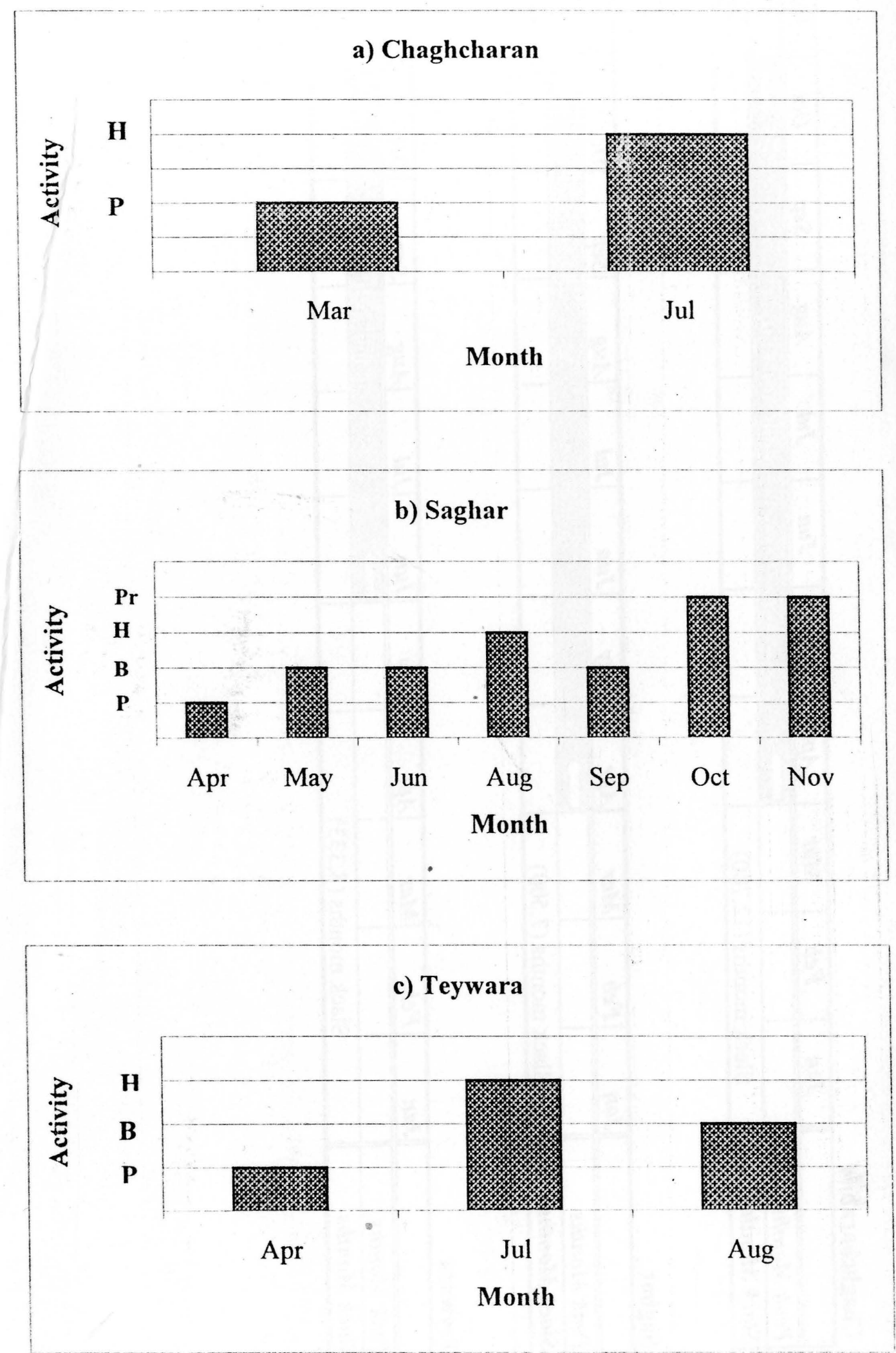

$\mathrm{P}=$ Preparation and Planting, $\mathrm{B}=$ Budding, $\mathrm{Pr}=$ Prunning, $\mathrm{H}=$ Harvesting 
- During this part of the year. little productive agricultural employment is available. Overall, however, wage employment locally is not a typical phenomenon as farms are small and can be managed by family labour.

\subsubsection{Farin Equipment and Farm Power}

None of the sampled households own modern farm equipment, sprays, farm vehicles, tractors, ploughs and other improved implements. All the houscholds surveyed employ animal traction power in labour-intensive tasks, such as land preparation and threshing of wheat. Sowing, weeding and harvesting are all done by hand. Figure IV 5 depicts the distribution of traction power among the sampled households. In Chaghcharan. 90 percent of the nouseholds owned one or two oxen, while the figure for Saghar and Teywara is, respectively, 75 percent and 70 percent. An average of 25 percent of farm households in each district own an ox. However, there is greater variation among owners of two oxen: 54 percent of farmers in Chaghcharan, 27 percent in Saghar and 11 percent in Teywara. Farms are relatively larger in Chaghcharan and thus the pattern of having two or more oxen is logical. In Chaghcharan we see a corresponding decline in the practice of renting oxen for farm use, while this practice is quite common in the other two districts.

Since land preparation is an arduous task, farmers are willing to invest a lot in oxen to ease the burden. Keeping an ox is an expensive proposition as its upkeep can strain the budget. to some extent. However, renting is also a costly alternative, with rents for a pair of bullock around Afs. 170,000 per day. Where renting is not a viable option, households help each other. Very small farmers cannot afford to buy, rent or pair oxen. Relatives who share their oxen for a few days free of charge may then help these out. Where a sharecropper works on his own lind as well as that on the landlord, he might as well use the landlord's oxen on his own land. Rarely does it happen that farmers have to till the soil using just their own two hands. The maximum level of technology that is used is, therefore, a pair of bullocks.

\subsubsection{Yield Analysis}

Table IV.3 presents the average wheat yield obtained by the sampled houscholds. The table alsc 'onks at the critical factors that might affect yield. 1: Chaghcharan. the mean yield is 191 
$\mathrm{kg} / \mathrm{jerib}$, while the figure for Saghar and Teywara is 331 and 265 respectively. In all three districts, the average yield is nowhere near that expected, and far below the average of 315 $\mathrm{kg} /$ jerib for Afghanistan'

Table IV.3. Comparison of Low and High Wheat Yields in the Case-Districts

Yield Group Percent of Mean Yield Seed Rate

$(\mathrm{kg} / \mathrm{j})$

Farms

$(\mathrm{kg} / \mathrm{j})$

$(\mathrm{kg} / \mathrm{j})$
Chemical Percent farmers fertiliser (kg/j) applying fertiliser

\section{Chagcharan}

$$
<=100
$$

69.0

27.0

0.5

(). ()

1.6

$101-150$

29.3

125.7

23.5

0.9

0.0

1.6

$151-250$

34.5

211.4

23.8

8.5

(). ()

$>250$

5.2

357.6

20.0

5.

0.0

1.6

\section{D)istrict Mean \\ Saghar}

100.0

190.9

23.5

3.7

(). 0

8.2

$<=200$

37.3

151.2

34.0

0

3.6

4.0

$201-300$

21.6

259

37.8

44.6

9.4

6.0

$301-400$

23.5

361.7

71.3

15

5.7

8.0

$>400$

17.6

553.3

40.8

47.8

2.5

10. 0

100.0

331.3

45.9

26.8

5.3

33.9

\section{Teywara}

$<=150$

32.1

119.1

$\cdot 25.9$

17.6

1.8

3.7

$151-250$

34.0

209

25.6

7.6

23.5

51.1

2

3.7

$>350$

13.2

424.9

29.6

104

8.5

16.9

District Mean

100.0

264.6

26.1

45.1

3.3

24.1

In Chaghcharan, 31 percent of farms have a yield of less than $100 \mathrm{~kg} /$ jerib. Although the seed rate is comparable to the other districts, farmers are not applying fertilisers. except very few who use on crops, besides wheat. The lack of input to fertilise land cropped with wheat is probably the single most important yield-limiting factor in Chaghcharan. The poor soil is another factor which is all the more reason to use fertiliser to inciease productivity.

\footnotetext{
'Agriculture Survey of $A$ fghanistan. Swedish Committee for Afghanistan. $14^{\text {th }}$ Report, 1991.

"N'ot manure, but a kind of fertile scil locally called "shora"
} 
In Saghar and, to some extent, in Teywara, the soil is relatively rich and the yield is better than in Chaghcharan. The variability in fertiliser application between the districts is due to the great quantity of "local" fertiliser applied in Sarghar district (see Table IV.4). Local fertiliser is used in bulk, while chemical fertiliser is applied in snaller quantities.

In all the districts, the wheat grown is local. None of the farmers have adopted improved seed variety. This is due to non-availability of improved wheat seed in the local markets. Better supply of seed and increased use of fertiliser can be expected to improve wheat yield.

\subsubsection{Fertiliser Application}

Fertiliser application is not very common. A large percentage of farmers do not use fertiliser at all (Table IV.4). Where chemical fertiliser is used, the practice is to apply all at a time. Farmers in Saghar and Teywara tend to be more receptive to fertiliser use than farmers in Chaghcharan. Generally, chemical fertilisers, like DAP and Urea are used sparingly while a large quantity of local fertiliser is applied per jerib. Supply shortage and high prices discourage farmers from using chemical fertilisers.

Table IV.4. Percentage Distribution of Households Applying Fertiliser on all Crops

Chaghcharan Saghar Teywara

\section{\% of HHs Applying:}

DAP

Urea

Manure

None

Average

Average Dose (kg/j):

DAP

Urea

Local Fertiliser ${ }^{1}$

\begin{abstract}
0
\end{abstract}
1.7

20

78.3
5.8

9.6

13.5

73.1

40

18.5

99.4
6

22

22

62

10.4

14.3

67.7

Tocal fertiliser is as defined earlier, Table IV. 3 
The rate of input directly influences the output. In Teywara, ferliliser is used but at a rate far below the level of $75 \mathrm{~kg} /$ jerib recommended by FAO, resulting in slightly better yields. In Saghar where the fertiliser rate is higher than the recommended level, we see a marked rise in yield.

\subsubsection{Profitability Analysis}

Fnterprise budgets are estimated for wheat and potato, as these are the two crops most widely grown in the case-districts (Table IV.5). $\wedge$ number of assumptions are made in calculating the budget figures. All figures are based on the mean values for the three districts. The budget proposed is for the hypothetical entity of the "average" farmer. It is assumed that the average farmer cultivates his own land; his inputs include seed and some fertiliser (dosage is the average calculated from all households); he hires a bullock for an average of 2 days for traction and 3 days for threshing wheat, and he does not hire labour. The table therefore gives an overview of the budget analysis for the average farmer.

Table IV.5. Production Costs and Returns for Wheat and Potato

Wheat

Qty per jerib Afs per jerib' Qty per jerib Afs per jerib'

\section{Inputs:}

Seed $(\mathrm{kg})$

27.7

213,443.9

D $\wedge$ P fertiliser $(\mathrm{kg})$

0.7

Urea fertiliser $(\mathrm{kg})$

Traction cost

1.1

2 days

$4,122.2$

$7,088.9$

$62,064.5$

Bullock

Labour

Total variable cost /jcrib

Gross return

$214.1 \mathrm{~kg}$
$93,096.8$
0.0

$379,816.3$

$1,649,637.5$

$1,269,821.2$
59.1

0.4

2 days

0 day's

0.0

$244,608.3$

0.0

$2,577.8$

$62,064.5$

0 days

0.0 $309,250.6$

$2,744.365 .1$ $2,435.114 .4$

Net return

The exchange rate at the time of the survey was $720 \wedge$ fs. per Pak Rupee or 38.00()$\wedge f$ s. per US $\$$. 
It can be seen from the table that net return from potato is higher than from wheat. The obvious reason is the higher yield per jerib of potato. Although the mean price for potato is lower than that of wheat, the higher output per jerib is sufficient to make potato a more worthwhile crop. However, there is not much of a demand for potatoes locally. and transporting the crop to the nearest market in Herat is too expensive. This explains in part why farmers are reluctant to allocate more land for this crop. Wheat is the staple crop grown for houschold use: any extra can also be sold locally.

\subsubsection{System Constraints}

C'rop productivity is influenced by a number of factors, some of which have heen discussed above. Problems like weeds. diseases and pests can also attack crops and thus lower yiclds. In the survey. farmers were asked to rank the factors that limit crop productivity. The response is presented graphically in Figure IV.6. In this arable land scarce province, irrigation water emerges as the single most important factor affecting crop yield. The spread of pests and diseases is another factor. gauged by the fact that up to 55 percent of the respondents in (haghcharan regard this as their second important yield-limiting factor. It is also widespread in the other two districts. where around 30 percent of people regard it the most important yicld-limiting factor.

I ack of good seed quality in the market is also a major problem faced by farmers. The highest percentage of respondents quoted poor seed quality / lack of improved seed as the third and fourth limiting factors for low crop yield. There is also a dearth of fertilizer and chemicals locally. All these factors contribute to low productivity.

I ack of traction power is also an issue in Chaghcharan and Saghar. hut was not deemed important by farmers in Teywara. Surprisingly, Teywara has the highest number of households without an ox (sce Figures IV.5), but this is offset by the highest rate of renting. It is interesting to note that all but a tiny proportion of farmers did not consider labour shortage to be a problem. This is because most farms are small enough to manage with family labour without requiring wage lahour. 
Figure IV.6 Factors Affecting Crop Yield

A) First and Second Limiting factors

\section{First Limiting Factors}

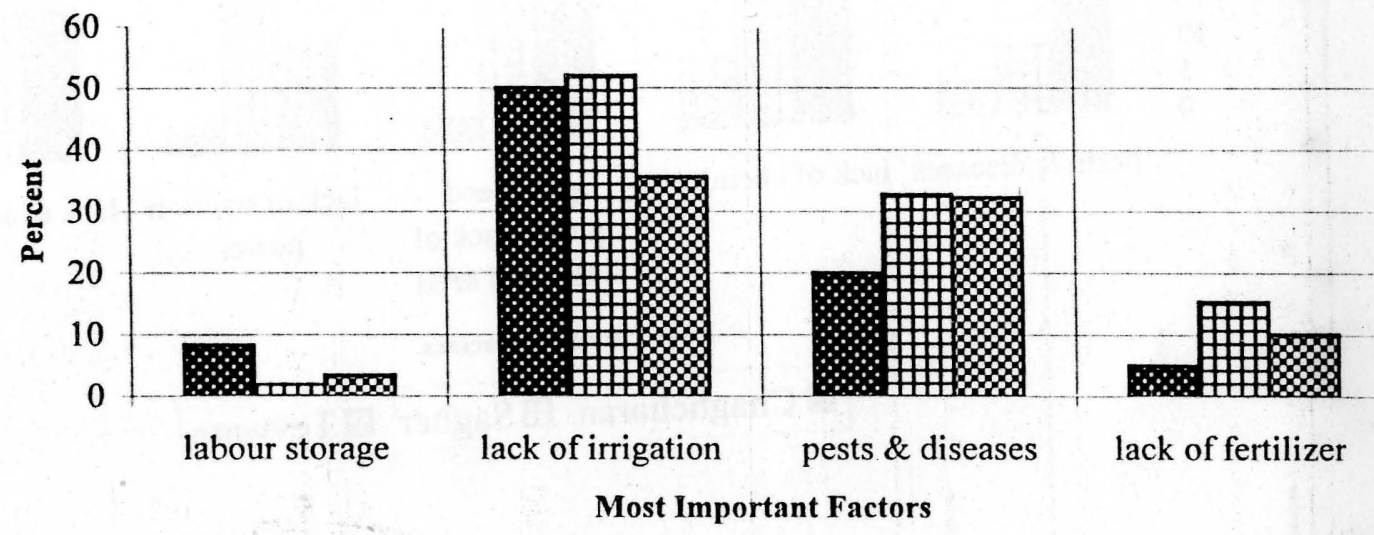

Chaghcharan $\boxplus$ Saghar Teywara

\section{Second Limiting Factors}

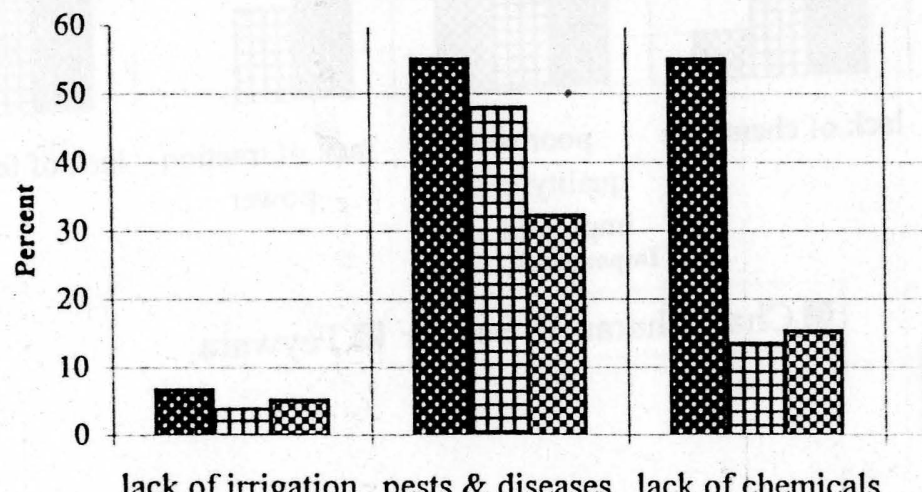

lack of irrigation pests $\&$ diseases lack of chemicals

Most Important Factors

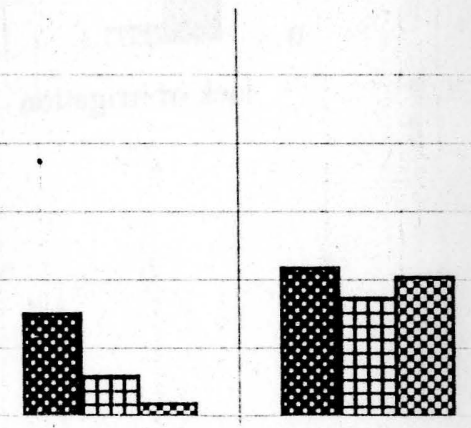

poor seed lack of fertilizer quality/lack of

improved seed

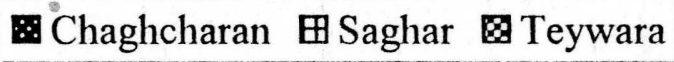




\section{B) Third and Fourth Limiting factors}

Third Limiting Factors

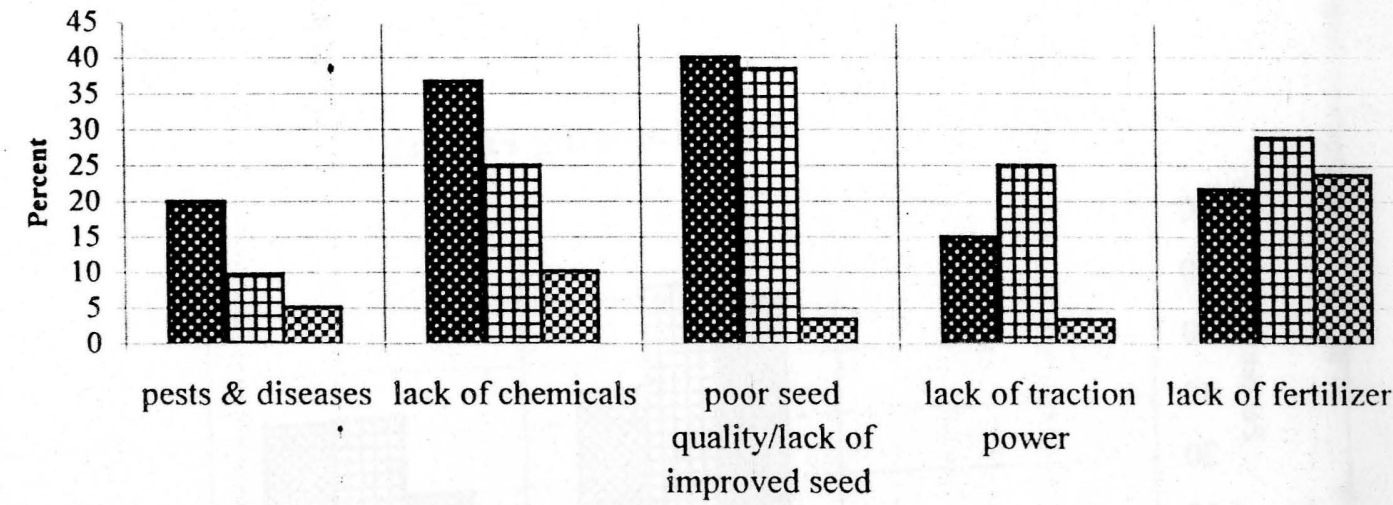

Most Important Factors

Chaghcharan $\boxplus$ Saghar $\quad$ Teywara

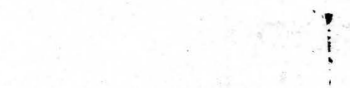

\section{Fourth Limiting Factors}

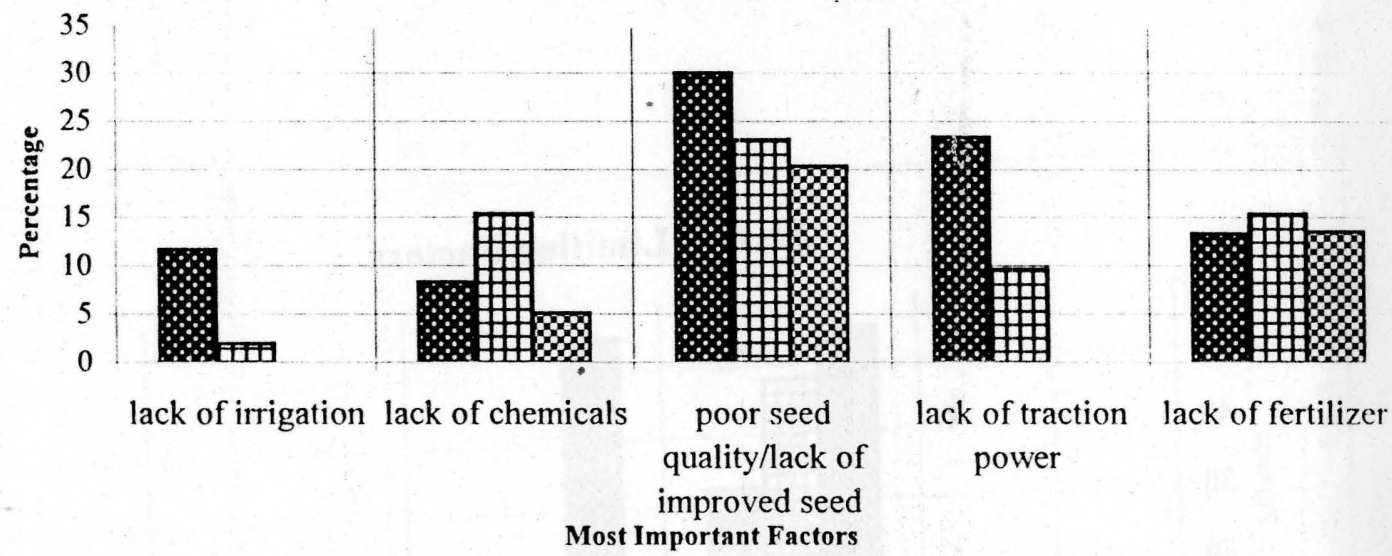

Chaghcharan $\mathbb{\text { ⿴囗十 }}$ Saghar Teywara 


\subsubsection{Agronomic Constraints}

I ow-technology agriculture, as witnessed in the sample districts. is highly subicet to the whims of the weather. (li ratic conditions are not in the contro! of the farmer hut they affect his farming practices nonc lheless. Farmers were asked to rank the constraints imposed by climatic conditions on their crops. The results are summarised in Table IV.6 and can also be seen pictorially in Figure IV.7. Frost and heavy rain lead to crop failure. whereas late rain causes pests and diseases. L ate rain also affects crop germination. Heary ain. hy contrast. causes the sown seeds to rot.

Table IV.6. Summary statistics for agronomic constraints (percentage distribution of households)

\begin{tabular}{|c|c|c|c|c|}
\hline & Main Iffect & Chaghcharan & Saghar & leywara \\
\hline \multirow[t]{2}{*}{ rost: } & Poor germination & 3.27 & 1.88 & $3 . \overline{7}$ \\
\hline & Poorino harvest & 1.63 & 9.43 & 9.25 \\
\hline \multirow[t]{2}{*}{ Ileavy rain: } & Poor gomination & 8.19 & 1.88 & 16.67 \\
\hline & Sown seeds rot & 4.76 & 5.67 & -- \\
\hline \multirow[t]{3}{*}{ Ileavy snow: } & Poor gemination & 1.63 & 20.75 & 5.55 \\
\hline & Sown socds rot & 21.31 & 32.07 & 3.33 \\
\hline & Pest and diseases & 11.47 & 7.54 & 1.85 \\
\hline \multirow[t]{2}{*}{ I ate rain } & Pest and diseases & 13.11 & 5.67 & 1.85 \\
\hline & Poorinoliarvest & 4.76 & 1.88 & 3.7 \\
\hline
\end{tabular}


Figure IV.7. Agronomic Constraints

Risk (I)
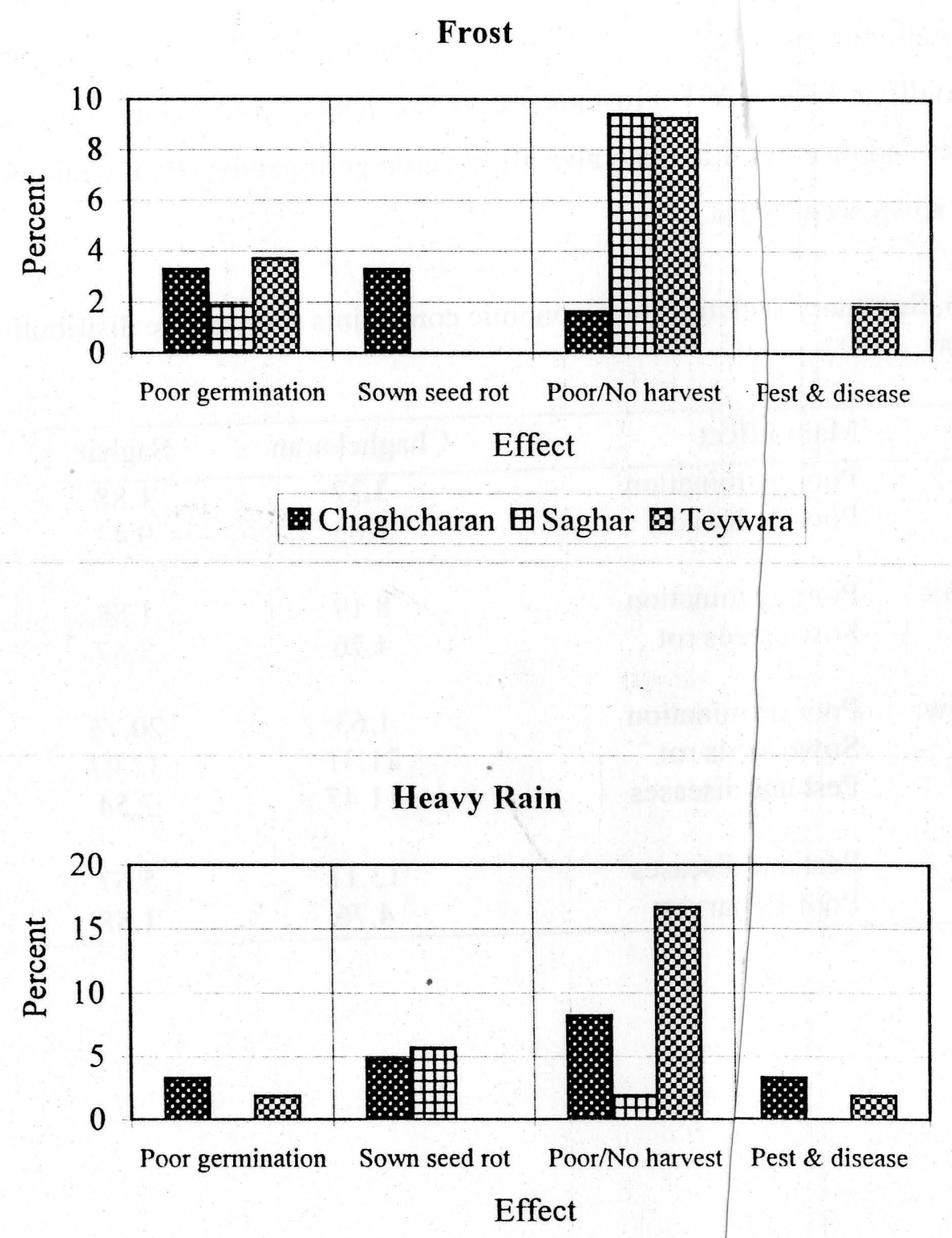

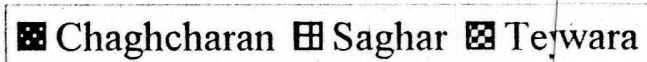



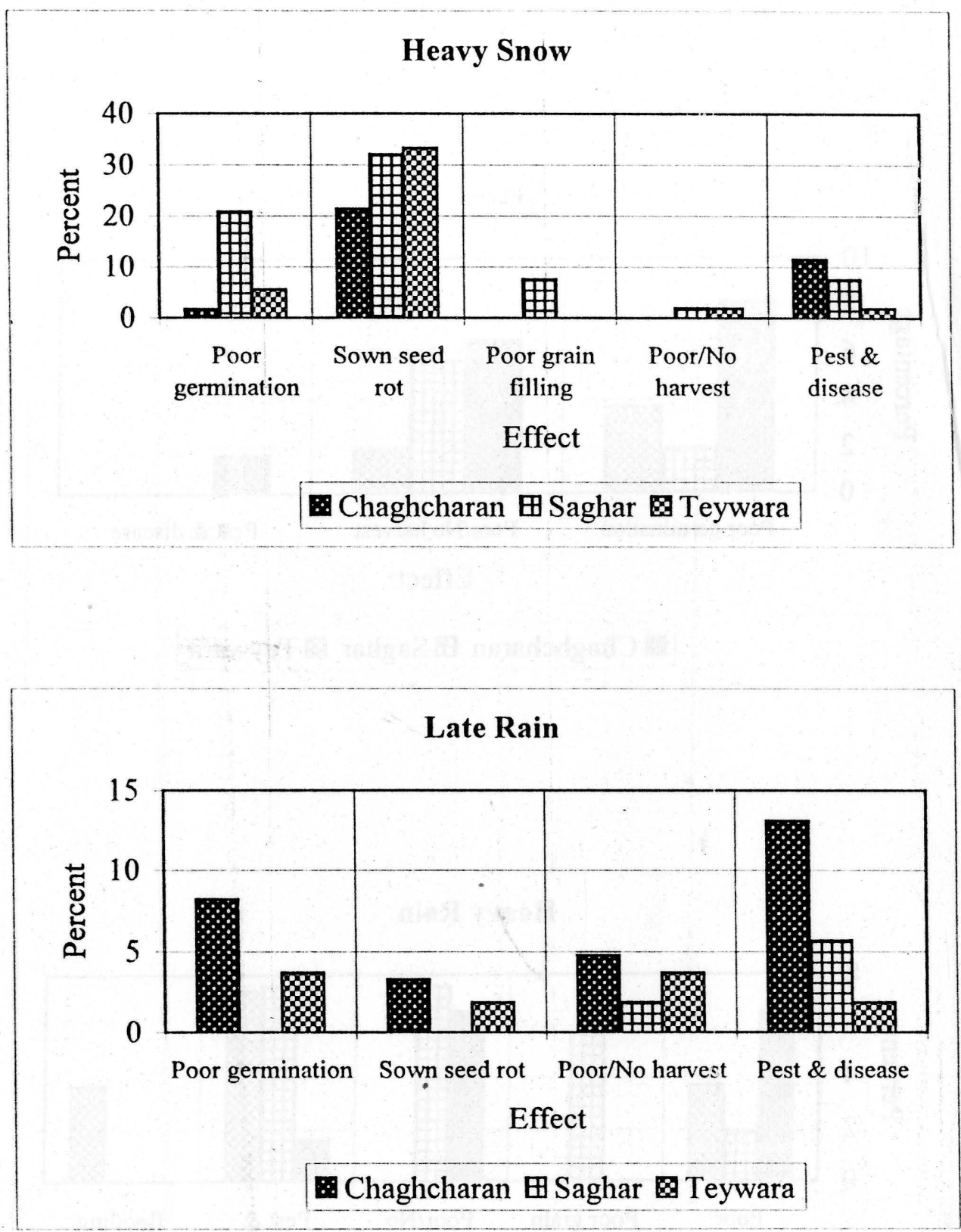


\section{Risk (II)}

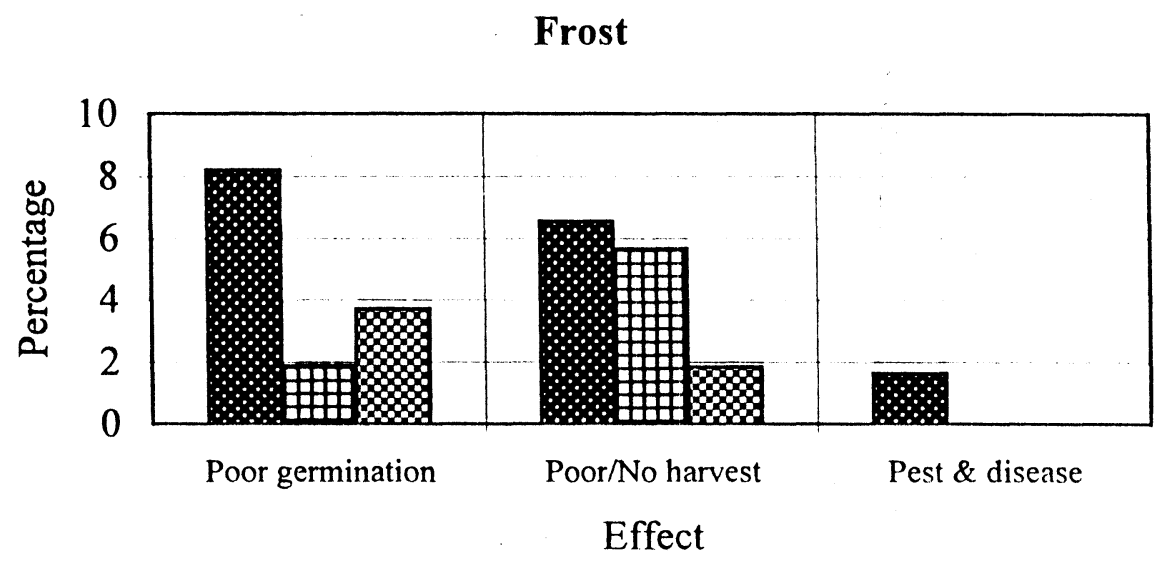

Chaghcharan $\boxplus$ Saghar Teywara

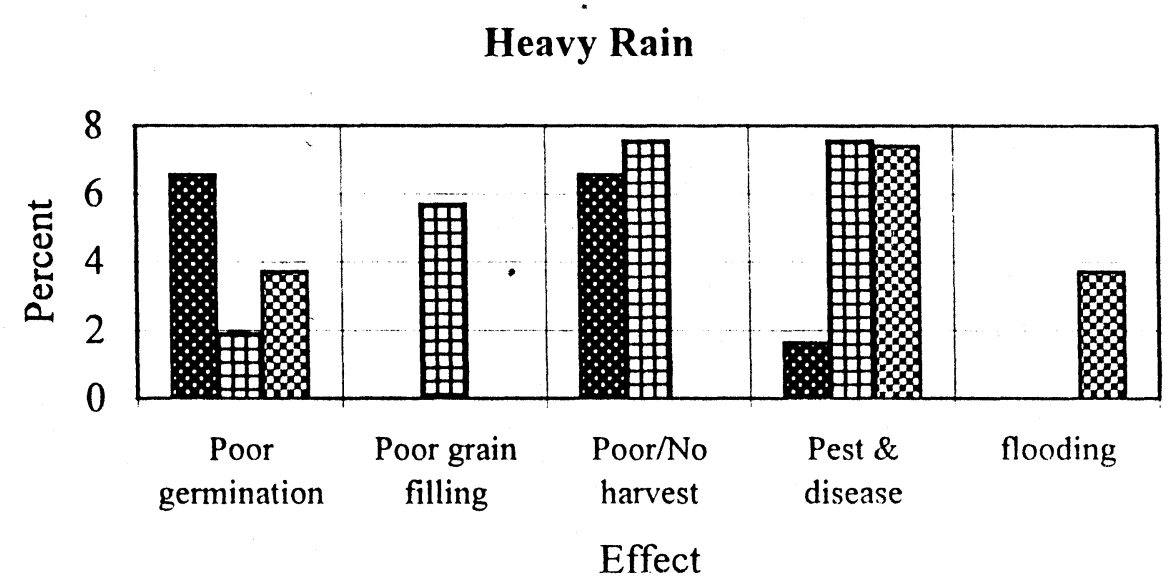

Chaghcharan $\boxplus$ Saghar $\quad$ Teywara 
Increased food production is critical to reducing vulncrability and improving livelihood security. In the context of $\Lambda$ fghanistan, where markets are poorly developed to engage and achieve better income. livelihood security depends largely upon own production. Livelihood insecurity is further maximised through a complex system of social and economic institutions. some of which ate discussed in this section.

\subsection{Narketing of Agricultural Products}

The average farmer in (Ghor grows crops to feed his family, and not for marketing as such. This conclusion is based on the data related to marketing of "surplus" crops. (Only two farmers in Teywara claimed to market surplus wheat, with the remainder storing the entire harvest (or their share of it) for use over the long winter. Potatoes. on the other hand. are grown as a cash-cum-subsistence crop. The sale of potatoes is not very widespread. however: only 23 percent of farmers who grew potatoes said they had sold their surplus potatoes in the market. The remaining 77 percent of potato-growing farmers did not have enough surpluses to sell.

Table V.1. Marketed Surplus as a Proportion of Total Output (for those selling only)

\begin{tabular}{lccc} 
& Chaghcharan & Saghai & Teywara \\
\hline Mean Potato output (kg) & 616.7 & 300 & $29 \overline{3} .3$ \\
Percentage marketed' & 33.2 & 41.7 & 60 \\
\hline & Percentages are calculated after deducting amount given to landlords &
\end{tabular}

The average potato output is highest in Chaghcharan. compared to Saghar and Teywara.

However. almost 67 percent of the output is used for home consumption and only 33 pereent is marketed (see Table V.1.). As seen earlier (Table IV.5), the net return from potato is much higher than from wheat. If more farmers were to grew potatoes for marketing purposes, or alternatively if those who grew potatoes market a higher percentage of their output, the net return for the farmers would be greater. Cash in hand could then be put to better use. including meeting the demand for wheat. This does not seem to be the case. however. Since markets are poorly dereloped, subsistence security plays the most important influence in 
thousehold decision-making. In effect, therefore, the process of transformation from subsistence to a market economy is thwarted. At present, households are neither autonomous subsistence producers nor fully engaged in the market. Although participation in the market could increase their potential incomes and improve livelihood security, inadequate physical and institutional infrastructure constrain market development. Farmers were asked to rank the problems they faced in marketing their crops. As stated earlier, most farmers did not have any surplus to market. Extra produce was small - therefore it was not economical to transport it to the market. Besides this, poor road condition and lack of transport were cited as major constrains to the development of marketing (Table V.2).

Table V.2. Constraints to Marketing (in percentages)

\begin{tabular}{lccc}
\cline { 2 - 4 } & Chaghcharan & Saghar & Teywara \\
\hline Surplus too small & 59.0 & 30.0 & 39.0 \\
Poor road condition & 3.0 & 12.5 & 4.0 \\
Lack of transport & 5.0 & 7.0 & 4.0 \\
No time & 0.0 & 2.0 & 0.0 \\
\hline
\end{tabular}

\subsection{Food Security}

\subsubsection{Direct Food Entitlement}

For the majority of farm households, survival depends on food produced by themselves (direct entitlement). The crops grown on their farms are the most important source of food. both for consumption and cash. Wheat, maize, potatoes, vegetables, fruit - whatever combination of these is grown - determine the diet of household members. When looking at the basic issue of food security, therefore, we need to look no further than the crops grown by households. Tables V.3 and V.4 present statistics for the output of wheat. which is the staple crop in all the three districts.

Table V.3. Mean Wheat ()utput per Household (kg)

\begin{tabular}{lcccccc}
\hline & Overall & \multicolumn{4}{c}{ Household Size } & F. sign \\
\cline { 3 - 6 } District & Mean & $\mathbf{2 - 5}$ & $\mathbf{6 - 9}$ & $\mathbf{1 0 - 1 3}$ & $>\mathbf{1 3}$ & level \\
\hline Chaghcharan & 1875.6 & 1163.6 & 1355.9 & 1853.8 & 3384.6 & 0.000 \\
Saghar & 1211.7 & 907.5 & 966.75 & 1691.9 & 1172.8 & N.S. \\
Teywara & 1046.0 & 688.9 & 1282.9 & 975.0 & 1389.0 & N.S. \\
F. sign. Level & 0.000 & & & & & \\
\hline
\end{tabular}


There seems to be a lincar relationship hetween household size and wheat produced in ('haghcharan. With the mean wheat output standing at $1.876 \mathrm{~kg}$ per household. variation between sample household groups is highly significant. Although the soils are poor, fertiliser and yields are also low, households in Chaghcharan have achicred highest output because of larger area cropped. In Saghar and Teywara, by contrast yields are low and the average area cropped is also small - hence the output per household is also low. Inter-houschold variation in the mean output is not significant, however.

Table V.4. Per Capita Availability of Wheat Grain

a) By household size

\begin{tabular}{lccccc}
\hline District & Orerall & \multicolumn{4}{c}{ Household Size } \\
\cline { 3 - 6 } & Mean & $\mathbf{2 - 5}$ & $\mathbf{6 - 9}$ & $\mathbf{1 0 - 1 3}$ & $>\mathbf{1 3}$ \\
\hline Chaghcharan & 183.7 & 245.2 & 179.5 & 154.5 & 174.6 \\
Saghar & 140.8 & 296.8 & 105.3 & 152.5 & 60.5 \\
Teywara & 113.0 & 156.3 & 101.4 & 66.6 & 73.5
\end{tabular}

h) By farm size

\begin{tabular}{lccccc} 
& Orcrall & \multicolumn{5}{c}{ Household Size } \\
\cline { 3 - 6 } & Mcan & $\mathbf{0 - 6}$ & $\mathbf{6 . 1 - 2 0}$ & $\mathbf{2 0 . 1 - 6 0}$ & $>\mathbf{6 0}$ \\
\hline Chaghcharan & 183.7 & 51 & 194 & 195.5 & 250 \\
\cline { 3 - 6 } & & $\mathbf{0 - 2}$ & $\mathbf{2 . 1}-\mathbf{1 0}$ & $\mathbf{1 0 . 1 - 2 0}$ & $>\mathbf{2 0}$ \\
Saghar & 140.8 & 65.6 & 93.8 & 118.5 & 357.7 \\
Teywara & $113 .()$ & 58.5 & 115.5 & 153.4 & 153.2 \\
\hline
\end{tabular}

Note: Per capita calculated hy exciuding landlord share

The size of household seems to be inversely related with food available to each member (Table V.4.). That is, larger households have lower per capita food availability. While the obverse is true for small household size groups. On the other hand. one can observe a direct relationship between farm size and per capita food availability. The larger farms are more prosperous and achieve a higher per capita wheat grain. The figure for small farms. especially those falling in the lowest size category, is well below the recommended amount of $175 \mathrm{~kg}$ per person per annum (F^O), cited in SC $\Lambda$ 1992).

Although per capita figures for wheat are not as bleak as in other parts of $\Lambda$ fghanistan, one must remember that they represent averages. Distribution/aceess is as critical as gross output. $\Lambda$ s stated in the WIP $\triangle$ ssessment Mission to Ghor (1997). "there are pockets |of areas| with wheat deficit and surplus." Malnutrition exists even though it is not aculc. Vulnerability to 
food shortage can occur due to lack of access to get it, even when surpluses are available in the market. The sections ahead look at the extent of food deficit and the success or otherwise of various coping stratcgies adopted by farm households.

\subsubsection{Indirect Food Entitlement}

The table below looks at indirect food entitlement by calculating the percentage of houscholds experiencing food deficit. It is apparent that a large percentage of farm households in all the three districts face seasonal food deficit. Most of these experience food shortages in the pre-harvest season when wheat is most costly. Figure V.I shows that food shortage is most widespread in mid-summer. In Saghar, the early summer months pose the higgest problem. Most households face shortages from spring, and only a small percentage of houscholds reported shortages as early as the winter months.

Table V.5. Percentage Ilouseholds Experiencing Food Deficit

\begin{tabular}{lccc} 
Food shortage? & Chaghcharan & Saghar & Teywara \\
\hline Yes & 80.65 & 92.45 & 85.18 \\
No & 19.35 & 7.55 & 14.82 \\
\hline
\end{tabular}

\subsubsection{Coping Strategies}

Coping with a food deficit involves relying on other means to bolster food supply. If there are no other means of getting food, one alternative, though drastic, would be to decrease the number of meals per day. This was not found to be the case though, as villagers reported an average of three meals per day in both summer and winter seasons. (Only 2.5 percent of respondents claimed to have 4 meals per day during the summer. However. the quality and quantity of meals could not be ascertained. In the cold winter season. caloric requirements tend to be high, yet the number of meals is the same, 4 per day.

As food deficit is evident. specific coping strategies have evolved which form a support network for those houscholds facing this problem. However. this also forms a "vicious circle", as the next year brings further food shortage and houscholds end up more heavily in debt or stripped of their assets. Each coping strategy is associated with social or economic repercussions, and is delineated in Figure V.2. 
FigureV.1 Food Deficit Seasons

a) Chaghcharan
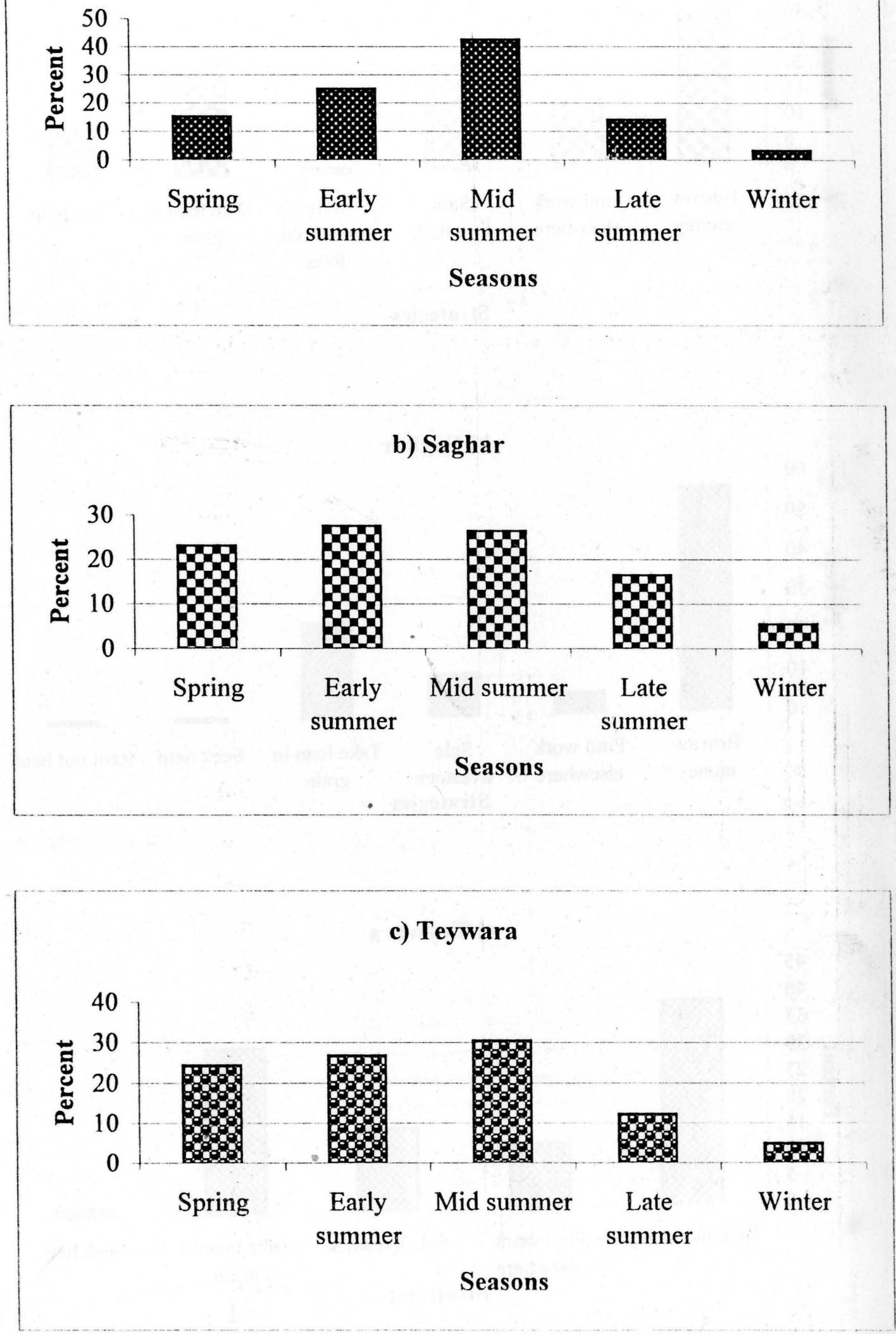
Figure V.2 Strategies to Meet Shortfall

a) Chaghcharan

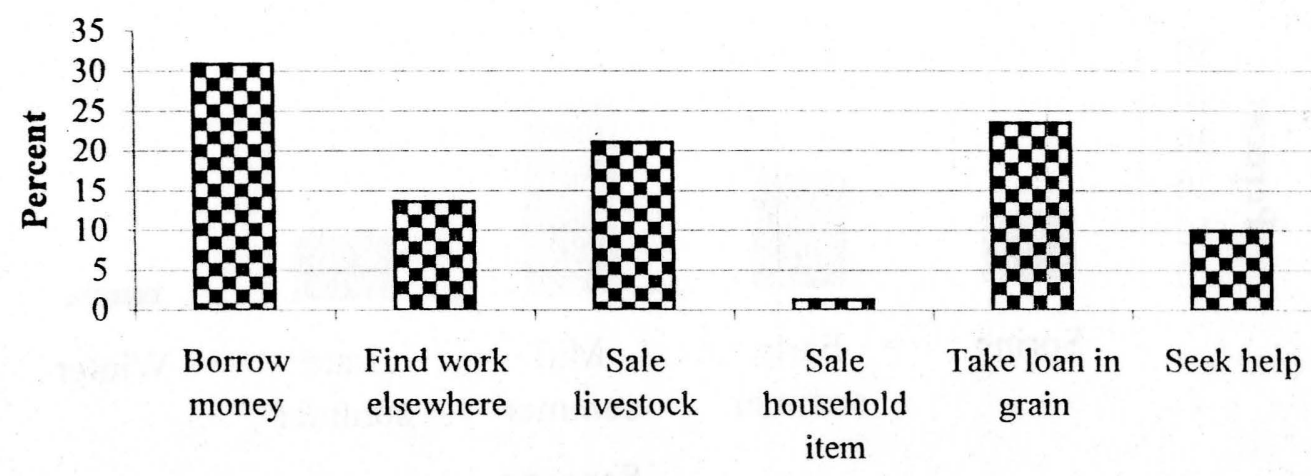

Strategies

b) Saghar

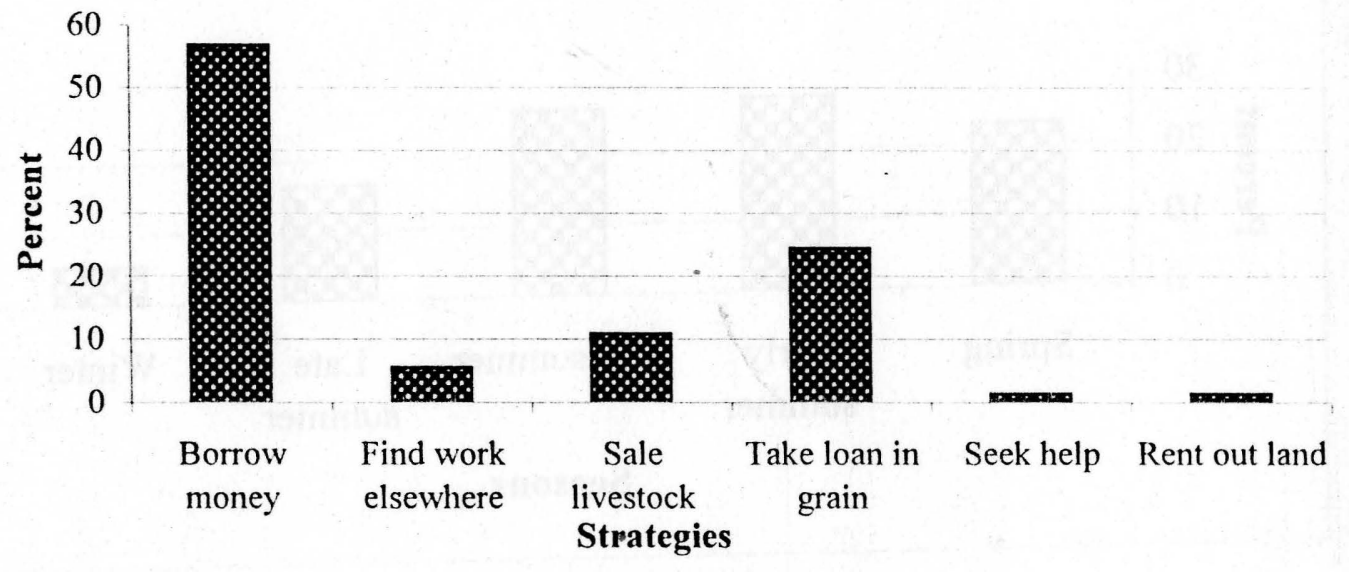

c) Teywara

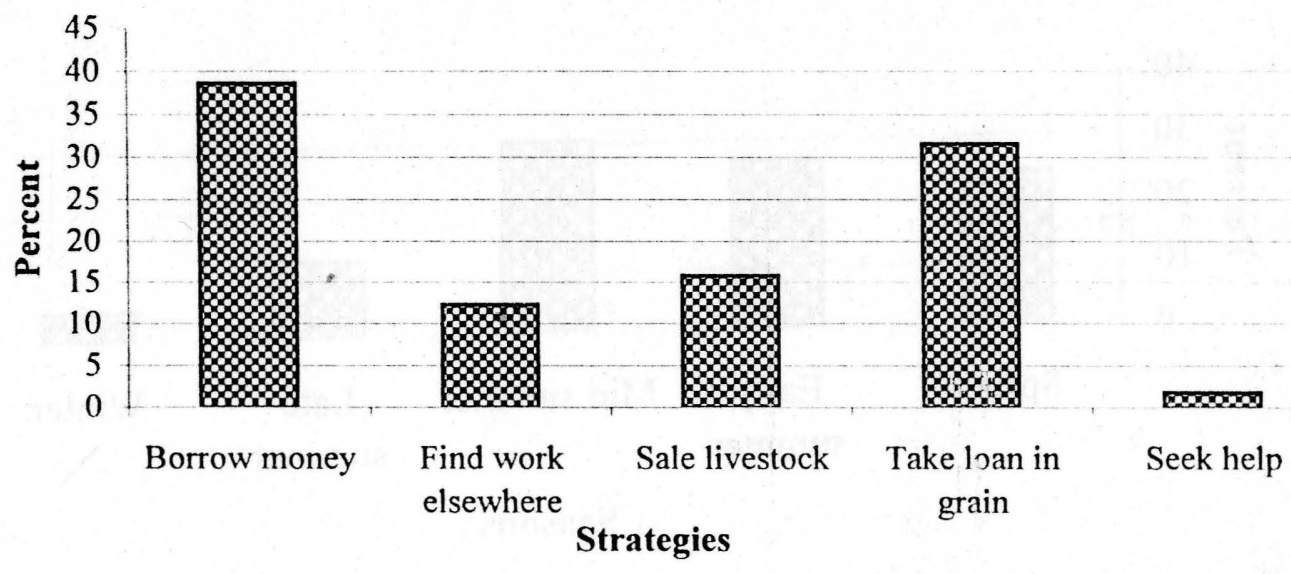




\subsubsection{Food Purchase}

Many households facing food shortage resort to borrowing wheat and other grains. This mechanism works as long as enough wheat is produced locally to cater to the farmers' needs. Wheat is also sold in the local markets, though not in bulk. If houscholds cannot borrow wheat, they resort to borrowing money in order to purchase wheat. $\Lambda$ ccess to cash loan is, therefore, critical to ensure adequate food supply.

Table V.6. Frequency of Travelling to Nearest Market (percentage of sample population)

\begin{tabular}{lccc}
\hline a) Chaghcharan & Daily & Weekly & Monthly \\
\hline - Once & 1.61 & 24.19 & 40.32 \\
- Twice & 0.0 & 1.61 & 19.35 \\
- More than twice & 0.0 & 0.0 & 1.61
\end{tabular}

b) Teywara Daily Weekly $\quad$ Monthly

- Once

- Twice

- More than twice
0.0

0.0

0.0
33.3

1.85

1.85
55.5

5.5

0.0

\section{c) Saghar}

- Once

- Twice

- More than twice

\section{Daily} 0.0

0.0

0.0
Weekly 16.98

3.70

0.0
Monthly 64.15

11.32

\subsection{7}

Farmers were asked to record the number of times they traveled to the nearest market. Although they travel to market for a variety of reasons, the overriding reason is to purchase food, as depicted in Figure V.3. Selling crop and livestock are not major reasons to travel to markets. Table V.6 shows how frequently people travel to the nearest markets to buy food and other basic necessities, such as clothing and medicine. Predictably, a substantial number of the households travel to markets every week, and a large percentage also go once or twice 
Figure V.3 Purpose of Traveling to Market

(a) Chaghcharan

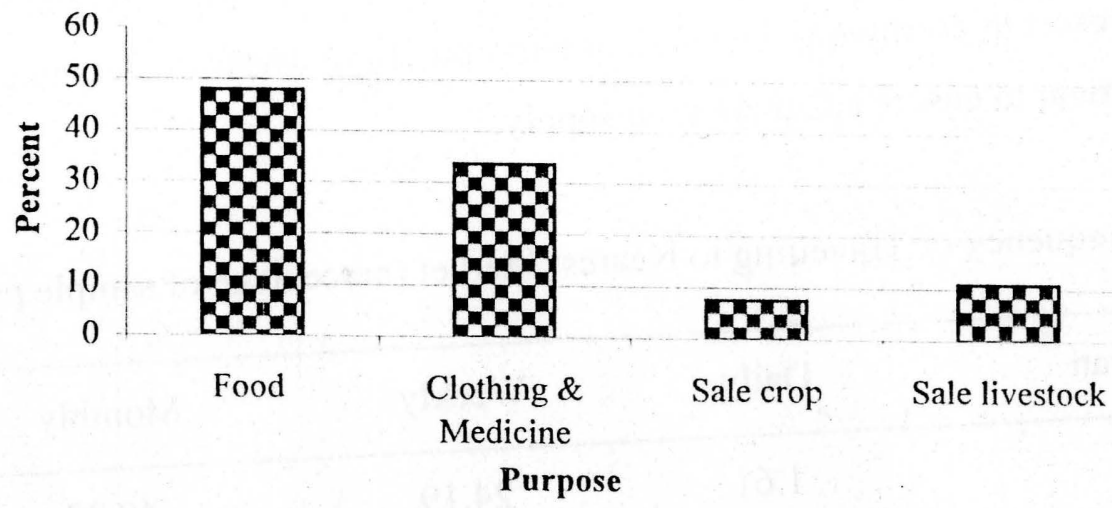

(b) Saghar

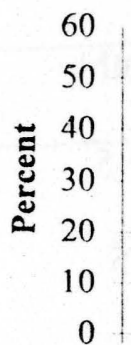

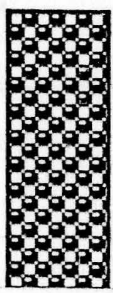

Food
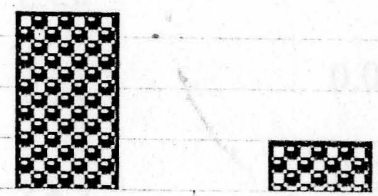

monction
Clothing \&
Mediçine
Purpose
Sale crop

Sale livestock

(c) Teywara

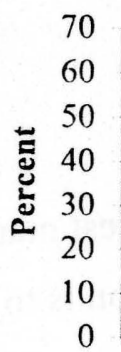

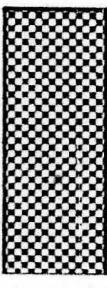


a month. Since the provincial centre is in Chaghcharan, one would expect villagers from this district to frequent the market more, but this pattern is not discernible from the survey.

Surplus wheat disposal pattern can be gauged from Table V.7. Houscholds with a surplus of wheat tend to sell it immediately after the harvest. This is also the time when excess supply drives wheat prices down. Thus, those households selling at th.: time get relatively less money to buy essential items, such as food and clothing for the harsh winter season. With stocks depleted so soon. many households later run into food shortages and have to purchase wheat at accelerated prices firom the market, or else rely on non-market transfers. This pattern is regular and pronounced, with the result that many households experience acute food shortages from March to August.

Table V.7. Surplus Disposal Pattern and Prices (percentage of those selling)

$\begin{array}{cc}\text { Immediately after harvest } & \text { Within three months } \\ \% \text { selling } \% \text { received } \% \text { received } \\ \text { good price bad price }\end{array} \quad \begin{gathered}\% \text { received } \% \text { received } \\ \text { good price bad price }\end{gathered}$

\begin{tabular}{lcccccc}
\hline Thaghcharan & 78.5 & 63.64 & 36.36 & 21.4 & 66.67 & 33.33 \\
Saghar & 91.6 & 27.27 & 72.73 & 8.3 & 0.00 & 100.00 \\
Teywara & 80.0 & 12.50 & 87.50 & 20 & 100.00 & 0.00 \\
\hline
\end{tabular}

\subsubsection{Casual Labour}

Wage labour is not widespread locally, as households rely on their own labour to complete essential farm tasks. Many households also rely on traditional forms of inter-household cooperation to meet on-farm labour shortages. Households offer their labour in the lean months when they have depleted their food and cash reserves (Figure V.5). The slack period of agricultural activity. stretching from November to . March. provites the lowest rate of daily wages for hired labour. around 20,000 Afs per day (Figure V.6). Thus we can sce that casual labour, as a coping strategy. is not a very effective means of livelihood security. 


\subsubsection{Labour Migration}

Since wage labour is not in great demand locally. men migrate to other places in search of employment. The head of the household or a son who is of age would migrate to places such as Herat. Helmand. Kandahar. Farah or else cross the border into Iran. Scasonal as well as long-term migration is a regular activity, which vouches for its effectiveness as a coping strategy.

Table V.8. I abour Migration Rate (as percentage of households with persons migrated)

\begin{tabular}{lccc} 
& Chaghcharan & Saghar & Teywara \\
\hline No. of persons migrated: & 12.9 & 9.4 & 22.2 \\
- One & 0 & 11.3 & 3.7 \\
- Two & 0 & 0 & 1.8 \\
- Three & & & \\
\hline
\end{tabular}

The percentage of houscholds with more than two persons migrated is negligible. In (haghcharan. 13 percent of the sampled households have one family member away. In Saghar and Teywara. migration is more popular (Table V.8). One of the reasons. is the "pull factor" to poppy-growing areas to work during harvesting. Although poppy growing is nonexistent in the case-districts, both Saghar and Teywara are located on the horders of Helmand. Farah and Kandahar which have extensive poppy crops. Scasonal migration to these areas, during the poppy harvesting months, is quite lucrative and explains the higher rate of migration from these two districts.

\subsubsection{Credit}

The survey data suggest a very high level of credit transaction in the case-districts (Table V.9). Around 85 percent of households across districts were involved in credit. The amount horrowed was on average hetween 2 and 3.5 million $\Lambda f$ ser houschold. though it varied greatly from household to household. The highest percentage of loan taken was in the range of 1 to 2 million $A$ s. In Saghar, 33 percent of households also reported loan of between 3 and 7 million Afs. which is much higher than the corresponding figure for the other two districts. This may be because Saghar is relatively more prosperous district and there is more credit available there than in the other districts. 
Tahle V.9. Percentage of Simpled I Iouseholds Involved in Credit and the Size of I oan

\begin{tabular}{lccc} 
& Chaghcharan & Saghar & Teywara \\
\hline Percentage of houscholds horrowed & 77.4 & 9() .5 & 88.8 \\
Average amount borrowed $(\wedge \mathrm{fs} /$ household $)$ & 2.042 .292 & 3.312 .833 & 3.569 .245 \\
Amount borrowing $($ million $A$ fs) & & & \\
- $<1$ & 16.0 & 4.2 & 22.9 \\
- $1-2$ & 62.5 & 43.7 & 43.7 \\
- $2-3$ & 8.3 & 8.3 & 8.3 \\
- $3-7$ & 10.4 & 33.3 & 10.4 \\
- $>7$ & 2.1 & 10.4 & 14.5
\end{tabular}

The purpose of borrowing is, overwhelmingly, to purchase food (Table V.10). Other reasons. such as health care, clothing, social obligations, etc. account for a small percentage of loans. The chief sources of credit are relatives and local shopkeepers; the latter provide goods on credit with no interest. The usual practice is that borrowers agree to repay the loan after the harvest. but this happens rarely and much of the amount is rolled over to the next season.

Table V.10. Purpose and Source of Borrowing (percentage)

\begin{tabular}{lccc} 
& Chaghcharan & Saghar & Teywara \\
\hline Source of borrowing & 4.17 & 22.03 & 1.92 \\
- Friends & 72.92 & 50.85 & 53.85 \\
- Relatives & 16.67 & 20.34 & 36.54 \\
- Shopkeepers & 6.25 & 6.78 & 7.69 \\
Purpose of borrowing & & & \\
- Health care & 0 & 0 & 4.26 \\
- Food items & 91.11 & 95.83 & 85.11 \\
- Purchase of livestock & 0.0 & 0.0 & 2.13 \\
- Constructing a house & 2.22 & 0.0 & 0.0 \\
- Clothing & 4.44 & 2.08 & 4.26 \\
- Social (marriage. death, etc.) & 2.22 & 2.08 & 4.26 \\
\hline
\end{tabular}




\subsection{Household Income}

After studying all the above characteristics of households in the sample population, it is now possible to examine the data on income and expenditure and draw some conclusions from them. Table VI.1 presents the average annual income per household obtained from various sources.

Table VI.1. Percentage Distribution of Annual Income by Source and Farm Size (Afs.)

Source of income Farm Size

\begin{tabular}{|c|c|c|c|c|c|}
\hline a) Chaghcharan & $0-6$ & $6.1-20$ & $20.1-60$ & $>60$ & $\begin{array}{c}\text { Percent of } \\
\text { total }\end{array}$ \\
\hline Crop sale & 2.37 & 1.58 & 12.30 & 13.88 & 9.12 \\
\hline Fruit sale & 0.00 & 0.00 & 0.00 & 0.00 & 0.00 \\
\hline Wage labour & 93.68 & 16.98 & 24.87 & 0.00 & 20.72 \\
\hline Vegetable sale & 0.00 & 0.00 & 0.00 & 0.00 & 0.00 \\
\hline Firewood sale & 0.79 & 43.53 & 8.05 & 0.00 & 12.44 \\
\hline Remittance & 0.00 & 2.37 & 0.00 & 2.27 & 1.55 \\
\hline Livestock sale & 3.16 & 35.54 & 54.78 & 83.85 & 56.17 \\
\hline Percent of total & 12.29 & 24.61 & 20.22 & 42.88 & 100.00 \\
\hline b) Saghar & $0-2$ & $2.1-10$ & $10.1-20$ & $>20$ & $\begin{array}{c}\text { Percent of } \\
\text { total }\end{array}$ \\
\hline Crop sale & 2.83 & 1.18 & 5.92 & 46.97 & 4.50 \\
\hline Fruit sale & 2.83 & 1.26 & 2.84 & 14.41 & 2.41 \\
\hline Wage labour & 56.54 & 52.05 & 14.22 & 16.70 & 43.31 \\
\hline Vegetable sale & 4.24 & 0.95 & 0.00 & 0.00 & 1.16 \\
\hline Firewood sale & 0.00 & 0.00 & 1.42 & 1.04 & 0.34 \\
\hline Remittance & 7.07 & 19.56 & 11.85 & 0.00 & 15.37 \\
\hline Livestock sale & 26.50 & 25.00 & 63.74 & 20.88 & 32.92 \\
\hline Percent of total & 20.40 & 13.68 & 61.29 & 4.63 & 100.00 \\
\hline c) Teywara & $0-2$ & $2.1-10$ & $10.1-20$ & $>20$ & $\begin{array}{c}\text { Percent of } \\
\text { total }\end{array}$ \\
\hline Crop sale & 7.49 & 0.40 & 6.93 & 11.15 & 5.96 \\
\hline Fruit sale & 0.00 & 0.00 & 0.00 & 0.00 & 0.00 \\
\hline Wage labour & 85.47 & 72.10 & 70.26 & 48.82 & 67.93 \\
\hline Vegetable sale & 0.00 & 0.00 & 0.00 & 0.00 & 0.00 \\
\hline Firewood sale & 0.00 & 1.20 & 0.00 & 1.34 & 0.72 \\
\hline Remittance & 7.03 & 17.36 & 9.01 & 15.83 & 13.06 \\
\hline Livestock sale & 0.00 & 8.94 & 13.81 & 22.87 & 12.32 \\
\hline Percent of total & 24.73 & 15.67 & 32.06 & 27.54 & 100.00 \\
\hline
\end{tabular}


Looking at the total figures, it is apparent that wage labour is the major source of overall income, accounting for up to 68 percent in Teywara and 43 percent in Saghar. The high figures for Saghar and Teywara corroborate the earlier findings of a markedly higher rate of labour migration from these two districts. Migration would be to other provinces in Afghanistan in search of work; however, it could also be to other countries like Iran and Pakistan, as shown by the corresponding comparatively high figures for remittances. In Chaghcharan, the biggest income stems from livestock sale, accounting for more than half of the total income earned by households. Livestock is also extremely important in the other two districts - 33 percent in Saghar and 12 percent in Teywara. The sale of firewood also brings in 12 percent of the total income in Chaghcharan, making this another important source of income. Table VI.1 clearly indicates that the sale of crop is not a very important source of income; it constitutes 9 percent of the total income in Chaghcharan, 5 percent in Saghar and 6 percent in Teywara. The principal reason is that there is usually not enough surplus to sale, as agriculture is very much a subsistence nature and the primary aim of households is to satisfy own consumption. Among the districts, Saghar is the only one in which some income is generated from the sale of fruit and vegetables.

A look at the breakdown of income by farm size suggests some pattern. That is, wage labour, in general, is a major source of income among the smaller farri size groups compared to the larger farm sizes. The greatest variation is in Chaghcharan, where wage labour accounts for 94 percent of the income for the farm size group $<6$ jerib, but none for the largest size group $>60$ jerib. It would seem that large farms are more prosperous and the family members don't need to resort to wage labour for income purposes. Larger farms have also generated the highest percentage of income from selling crops. In Chaghcharan, livestock constitutes 84 percent of the income for farms over 60 jerib. Cash from livestock sale is another major source of income for all size groups, but the importance attached to livestock as a source of income varies is in relation to farm size. With increased farm size, there also follows increased amount of cash income generated from the sale of livestock. This is particularly the case in Chaghcharan and Teywara districts; this relationship does not follow a particular pattern in Saghar. Remittances and firewood sale also vary with no particular reference to farm size groupings. 


\subsection{Household Expenditure}

Average annual household expenditures are estimated for farm size groups and the results are presented in Table VI.2. Looking at the figures, it is evident that market purchase of food items accounts for the highest expenditure category for most households. Expenditure on wheat, as expected, is the single biggest cost element in all three districts; it constitutes about 46 percent of the total expenditure in Chaghcharan, nearly 51 percent in Saghar and slightly more than 50 percent in Teywara. The second most important expenditure component is clothing. More than 10 percent of the total expenditure in Chaghcharan and 9 percent in Saghar and Teywara is allocated for clothing. Not surprisingly, expenditure on tea is also high in all three districts - about 10 percent of the total expenditure in Chaghcharan and 12 percent in Teywara. The corresponding figure for Saghar is considerably low, 5 percent.

Gee is another important component of the total annual household expenditure. About 9 percent of the total spending in Chaghcharan and Saghar and nearly 8 percent in Teywara is spent on this commodity.

As can be seen from Table VI.2, the next comparatively important expenditure item is rice. The proportion of money spent on rice is much higher in Saghar, compared to the other two districts. In Saghar it accounts for 11 percent of the total expenditure while in Chaghcharan and Teywara, its share is 4 and 3 percent respectively. A considerable portion of the total expenditure ( 7 percent) is spent on kerosene in Chaghcharan, compared to 2 to 3 percent in Saghar and Teywara respectively. Expenditure on health, fuelwood, meat and sugar has comparatively smaller share and does not differ significantly between the districts.

An in-depth look at the expenditure pattern by farm size shows a negative relationship between the amount of money spent on wheat and farm size in all three districts (Table VI.2). That is, farms with smaller holdings spend more money on wheat, compared with farms of large size groups. This shouldn't be a surprise though, for smaller farms do not produce enough grain to satisfy demand for food and have to allocate, comparatively, more of their cash income to purchase wheat.

The remaining elements of the expenditure do not reveal definite pattern with relation to farm size. Apart from wheat, spending pattern is homogenous in the sample population, and the 
Table VI.2. Average Annual Expenditure by Source and Farm Size (Million Afs.)

\section{Chaghcharan}

\begin{tabular}{|c|c|c|c|c|c|c|c|c|c|c|}
\hline \multirow[t]{3}{*}{ Expenditure } & \multicolumn{10}{|c|}{ Farm Size } \\
\hline & \multicolumn{2}{|c|}{$0-6$} & \multicolumn{2}{|c|}{$6.1-20$} & \multicolumn{2}{|c|}{$20.1-60$} & \multicolumn{2}{|c|}{$>60$} & \multicolumn{2}{|c|}{ Total } \\
\hline & Amount & $\%$ & Amount & $\%$ & Amount & $\%$ & Amount & $\%$ & Amount & $\%$ \\
\hline Wheat & 15.4 & 49.41 & 11.3 & 43.59 & 12.7 & 45.09 & 16.7 & 44.88 & 56.0 & 45.92 \\
\hline Rice & 1.9 & 6.27 & 0.69 & 2.70 & 0.24 & 0.85 & 2.1 & 5.67 & 5.0 & 4.10 \\
\hline Gee & 1.6 & 5.21 & 2.4 & 9.38 & 2.4 & 8.67 & 4.5 & 12.09 & 10.9 & 9.01 \\
\hline Meat & 0.51 & 1.47 & 0.71 & 2.74 & 0.71 & 2.52 & 2.7 & 7.33 & 4.6 & 3.78 \\
\hline Tea & 5.5 & 17.78 & 2.6 & 10.18 & 1.5 & 5.35 & 2.2 & 6.03 & 11.9 & 9.76 \\
\hline Sugar & 0.41 & 1.31 & 0.54 & 2.11 & .38 & 1.35 & 0.79 & 2.11 & 2.1 & 1.74 \\
\hline Kerosene & 0.63 & 2.02 & 1.1 & 4.33 & 6.0 & 21.31 & 0.85 & 2.27 & 8.6 & 7.03 \\
\hline Fuelwood & 1.9 & 6.27 & 2.2 & 8.64 & 0.29 & 1.06 & 1.9 & 4.98 & 6.3 & 5.19 \\
\hline Health & 0.33 & 1.06 & 0.89 & 3.48 & 0.52 & 1.85 & 1.1 & 2.93 & 2.8 & 2.33 \\
\hline Clothing & 2.9 & 9.19 & 3.3 & 12.87 & 3.4 & 11.96 & 4.4 & 11.70 & 13.9 & 11.40 \\
\hline Total & 31.1 & 100 & 25.8 & 100 & 28.1 & 100 & 37.3 & 100 & 122.0 & 100 \\
\hline$\%$ of Total & & 25.41 & & 21.13 & & 22.99 & & 30.47 . & & 100.00 \\
\hline \multicolumn{11}{|l|}{ Saghar } \\
\hline \multirow[t]{3}{*}{ Expenditure } & \multicolumn{10}{|c|}{ Farm Size } \\
\hline & \multicolumn{2}{|c|}{$0-2$} & \multicolumn{2}{|c|}{$2.1-10$} & \multicolumn{2}{|c|}{$10.1-20$} & \multicolumn{2}{|c|}{$>20$} & \multicolumn{2}{|c|}{ Total } \\
\hline & Amount & $\%$ & Amount & $\%$ & Amount & $\%$ & Amount & $\%$ & Amount & $\%$ \\
\hline Wheat & 11.1 & 53.49 & 16.4 & 49.63 & 21.0 & 15.10 & 1.9 & 8.45 & 67.2 & 50.54 \\
\hline Rice & 2.3 & 10.88 & 3.3 & 10.13 & 3.6 & 2.61 & 5.5 & 2.49 & 14.8 & 11.09 \\
\hline Gee & 1.1 & 5.43 & 2.7 & 8.34 & 4.2 & 3.00 & 3.6 & 1.62 & 11.7 & 8.76 \\
\hline Meat & 0.60 & 2.89 & 1.2 & 3.68 & 1.2 & 0.88 & 3.4 & 1.52 & 6.4 & 4.81 \\
\hline Tea & 1.4 & 6.74 & 1.9 & 5.93 & 1.0 & 0.73 & 1.8 & 0.82 & 6.2 & 4.66 \\
\hline Sugar & 0.38 & 1.80 & 0.8 & 2.35 & 1.1 & 0.76 & 1.1 & 0.51 & 3.3 & 2.51 \\
\hline Kerosene & 0.41 & 1.96 & 0.62 & 1.88 & 0.71 & 0.51 & 0.84 & 0.38 & 2.8 & 1.94 \\
\hline Fuelwood & 0.20 & 0.96 & 1.7 & 5.27 & 0.67 & 0.48 & 0.96 & 0.43 & 3.7 & 2.68 \\
\hline Health & 1.5 & 7.33 & 1.1 & 3.22 & 1.4 & 1.01 & 0.84 & 0.38 & 4.8 & 3.63 \\
\hline Clothing & 1.8 & 8.52 & 3.2 & 9.57 & 3.1 & 2.25 & 4.3 & 1.94 & 12.4 & 9.29 \\
\hline Total & 20.8 & 100.0 & 32.9 & 100.00 & 38.1 & 27.33 & 41.1 & 18.54 & 133.0 & 99.92 \\
\hline$\%$ of Total & & 15.64 & & 24.80 & & 28.64 & & 30.92 & & 100.00 \\
\hline
\end{tabular}


Teywara

\begin{tabular}{|c|c|c|c|c|c|c|c|c|c|c|}
\hline \multirow[t]{3}{*}{ Expenditure } & \multicolumn{10}{|c|}{ Farm Size } \\
\hline & \multicolumn{2}{|c|}{$0-2$} & \multicolumn{2}{|c|}{$2.1-10$} & \multicolumn{2}{|c|}{$10.1-20$} & \multicolumn{2}{|c|}{$>20$} & \multicolumn{2}{|c|}{ Total } \\
\hline & Amount & $\%$ & Amount & $\%$ & Amount & $\%$ & Amount & $\%$ & Amount & $\%$ \\
\hline Wheat & 9.0 & 52.64 & 11.4 & 54.44 & 12.2 & 50.82 & 15.8 & 46.63 & 48.5 & 50.45 \\
\hline Rice & 0.40 & 2.34 & 0.51 & 2.42 & 0.13 & 0.54 & 1.5 & 4.37 & 2.5 & 2.62 \\
\hline Gee & 1.3 & 7.66 & 1.4 & 6.51 & 1.3 & 5.38 & 3.3 & 9.79 & 7.3 & 7.59 \\
\hline Meat & 0.60 & 3.53 & 0.72 & 3.41 & 0.85 & 3.56 & 1.5 & 4.52 & 3.7 & 3.86 \\
\hline Tea & 0.98 & 5.73 & 3.5 & 16.87 & 4.6 & 19.08 & 2.9 & 8.43 & 11.9 & 12.45 \\
\hline Sugar & 0.29 & 1.73 & 0.49 & 2.35 & 0.84 & 3.51 & 1.0 & 3.00 & 2.7 & 2.76 \\
\hline Kerosene & 0.82 & 4.78 & 0.60 & 2.88 & 0.43 & 1.81 & 0.74 & 2.17 & 2.6 & 2.70 \\
\hline Fuelwood & 0.99 & 5.82 & 0.62 & 2.96 & 0.11 & 0.46 & 0.34 & 1.01 & 2.1 & 2.16 \\
\hline Health & 1.8 & 10.39 & 0.41 & 1.94 & 0.95 & 3.96 & 2.6 & 7.76 & 5.8 & 6.01 \\
\hline Clothing & 0.92 & 5.40 & 1.3 & 6.22 & 2.6 & 10.89 & 4.2 & 12.32 & 9.0 & 9.39 \\
\hline \begin{tabular}{|l|} 
Total \\
\end{tabular} & 17.1 & 100.0 & 20.9 & 100.00 & 24.0 & 100.00 & 33.9 & 100.00 & 96.1 & 100.00 \\
\hline$\%$ of Total & & 17.82 & & 21.84 & & 24.98 & & 35.35 & & 100.00 \\
\hline
\end{tabular}


"percentage of money spent on different items does not differ between farm sizes. However, the overriding pattern is the lack of any "luxury" component in annual expenditure. Where the bulk of expenditure incurred is on foodstuff, it reflects the precarious nature of the economy. In such a scenario, off-farm income becomes all the more vital to household food security. 


\subsection{Livestock Population and Herd Composition}

Animal husbandry is a very important component of the Afghan economy. Unfortunately, over the last twenty years, a large number of animals have been lost, both directly from the war and indirectly farmers selling their animals for cash to buy food and other basic items (FAO, 1997). This may have affected the herd composition as well. Table VII.1 depicts a pattern in which sheep predominate over goats and cattle, whereas the goat:cattle ratio is near unity.

As can be seen from the table, sample households in Chaghcharan have the highest number of animals, 1,183 . With a total number of 675 animals, Saghar is placed second, while Teywara occupies third place. This pattern seems to be influenced by grazing land in which Chaghcharan has the most, followed by Saghar and Teywara. The overall ratios are all greater than unity, except for the sheep:goat ratio in Teywara. This means that sheep raising is more common than goat raising, and the rearing of goats is more widespread than that of cattle.

If one compares the ratios for the districts with those existed immediately before the war, a definite difference could be observed in the composition of the herd. The sheep:goat ratio is considerably low, but the ratio of sheep to cattle as well as of goat to cattle are much higher than that of the pre-war level. A comparison of these ratios in the districts under consideration leads to the same conclusion. This change indicates that livestock production in the districts has shifted away from cattle and towards smallstock. There are a number of possible reasons for this. Cattle, though extremely useful, are expensive to keep. It is also possible that as grazing land diminished and agricultural land became more intensively used, cattle replaced smallstock that could forage on shrubs. A third reason might be the physiological ability of sheep and goats to multiply quickly. This last attribute makes smallstock attractive, particularly to low-income households looking for quick recovery from the war. 
Table VII.1. Number and Overall Ratios of Livestock Population, 1973 and 1998

\begin{tabular}{|c|c|c|c|c|c|c|c|c|c|c|}
\hline \multirow{3}{*}{ District } & \multirow{2}{*}{\multicolumn{4}{|c|}{ Number of livestock, 1998}} & \multicolumn{6}{|c|}{ Overall ratios } \\
\hline & & & & & \multicolumn{3}{|c|}{$1973^{\mathrm{a}}$} & \multicolumn{3}{|c|}{1998} \\
\hline & Sheep & Goat & Cattle & Total & $\begin{array}{l}\text { Sheep: } \\
\text { Goat }\end{array}$ & $\begin{array}{l}\text { Sheep } \\
\text { Cattle }\end{array}$ & $\begin{array}{l}\text { Goat: } \\
\text { Cattle }\end{array}$ & $\begin{array}{l}\text { Sheep: } \\
\text { Goat }\end{array}$ & $\begin{array}{l}\text { Sheep: } \\
\text { Cattle }\end{array}$ & $\begin{array}{l}\text { Goat: } \\
\text { Cattle }\end{array}$ \\
\hline Chaghcharan & 712 & 259 & 212 & 1183 & 3.23 & 2.42 & 0.75 & 2.75 & 3.36 & 1.22 \\
\hline Saghar & 359 & 196 & 120 & 675 & 0.57 & 0.65 & 1.14 & 1.83 & 2.99 & 1.63 \\
\hline Teywara & 107 & 135 & 76 & 318 & 1.37 & 0.98 & 0.71 & 0.79 & 1.41 & 1.78 \\
\hline Total & 1178 & 90 & 408 & 2176 & 2.30 & 1.88 & 0.82 & 2.00 & & \\
\hline
\end{tabular}

${ }^{a}$ Derived from Table No.2, page 136, Historical and Political Gazetteer of Afghanistan, VOL.3, 1975. The data for 1998 refer to the Survey

In Table VII.2, having added the three species together, we have calculated the percentage of each species in the total herd for each district in 1998 and 1973. The data suggest that 60 percent of the animals raised in Chaghcharan are sheep, while goats and cattle are 22 and 18 percent respectively. This pattern is more or less the same in Saghar district, but it in the case of Teywara, only 34 percent of the total livestock population are sheep. Here, the percentage share of goats and cattle is much higher, compared with the other two districts. A comparison of the percentages derived from the survey data with those existed in 1973 clearly support the conclusion drawn earlier. That is, the share of smallstock has increased in the herd.

Table VII.2. Percentage Distribution of Animals as a Measure of Herd Composition, 1973 and 1998

\begin{tabular}{|c|c|c|c|c|c|c|}
\hline \multirow{3}{*}{ Livestock } & \multicolumn{6}{|c|}{ District } \\
\hline & \multicolumn{2}{|c|}{ Chaghcharan } & \multicolumn{2}{|c|}{ Saghar } & \multicolumn{2}{|c|}{ Teywara } \\
\hline & 1973 & 1998 & 1973 & 1998 & 1973 & 1998 \\
\hline Sheep & 58.07 & 60.19 & 23.00 & 53.18 & 36.28 & 33.65 \\
\hline Goat & 17.96 & 21.89 & 40.93 & 29.64 & 25.51 & 42.45 \\
\hline Cattle & 23.97 & 17.92 & 35.77 & 17.78 & 37.21 & 23.90 \\
\hline
\end{tabular}

Table VII.3 presents data on the distribution of livestock by species and farm size. The table reveals a positive relationship between the number of livestock owned and the size of farm operated in Chaghcharan. It is also evident that the number of total livestock is increasing from 74 in farm sizes 0-6 to 314 in farm sizes $6.1-20$, to 651 in farm sizes 20.1-60. 
However, it somewhat declines in farm sizes bigget than 60 jeribs of land. The same pattern could be observed when the relationship between each species of animal and farm size is considered in this district. For example, the number of sheep raised by smaller farmers is 46 , which gradually increases to 132,234 and 300 in the respective higher categories. A similar pattern is also observed in the case of other species of animals.

Table VII.3. Herd Structure: Distribution of Livestock in the Sample by Farm Size (number of households in parenthesis)

Farm Size

a) Chaghcharan

\begin{tabular}{|c|c|c|c|c|c|}
\hline & $0-6$ & $6.1-20$ & 20.1-60 & $>60$ & Total \\
\hline Cattle & $15(9)$ & $58(18)$ & $78(20)$ & $61(11)$ & 212 \\
\hline Sheep & $46(3)$ & $132(9)$ & 234 (14) & $300(10)$ & 712 \\
\hline Goat & $11(2)$ & $36(7)$ & $131(16)$ & $81(7)$ & 259 \\
\hline Donkey & $1(1)$ & $18(13)$ & $33(20)$ & $18(8)$ & 70 \\
\hline Horse & $0(0)$ & $2(2)$ & $4(4)$ & $4(3)$ & 10 \\
\hline Poultry & $1(1)$ & $68(12)$ & $171(20)$ & $127(9)$ & 367 \\
\hline Total & $74(13)$ & $314(61)$ & $651(94)$ & $591(48)$ & 1630 \\
\hline \multicolumn{6}{|l|}{ b) Saghar } \\
\hline & $0-2$ & $2.1-10$ & $10.1-20$ & $>20$ & \\
\hline Cattle & $12(60)$ & $52(22)$ & $31(8)$ & $25(4)$ & $\overline{120}$ \\
\hline Sheep & $12(2)$ & $276(19)$ & $53(5)$ & $18(2)$ & 359 \\
\hline Goat & $23(4)$ & $110(12)$ & $34(3)$ & 29 (4) & 196 \\
\hline Donkey & $10(7)$ & $33(2)$ & $12(7)$ & $7(5)$ & 62 \\
\hline Horse & $0(0)$ & $2(20$ & $3(3)$ & $3(0)$ & 8 \\
\hline Poultry & $13(3)$ & $50(14)$ & $26(7)$ & $39(5)$ & 128 \\
\hline Total & $70(22)$ & $523(91)$ & $159(33)$ & $121(20)$ & 873 \\
\hline \multicolumn{6}{|l|}{ c)Teywara } \\
\hline Cattle & $7(4)$ & $28(16)$ & $25(9)$ & $16(8)$ & 76 \\
\hline Sheep & $24(5)$ & $70(11)$ & $4(1)$ & $9(2)$ & 107 \\
\hline Goat & $18(3)$ & $54(9)$ & $28(7)$ & $35(4)$ & 135 \\
\hline Donkey & $5(5)$ & $21(16)$ & $15(9)$ & $15(8)$ & 56 \\
\hline Horse & $0(0)$ & $2(2)$ & $0(0)$ & $0(2)$ & 2 \\
\hline Poultry & $7(4)$ & $77(11)$ & $32(10)$ & $47(6)$ & 163 \\
\hline Total & $61(21)$ & $252(65)$ & $104(36)$ & $122(30)$ & 539 \\
\hline
\end{tabular}

In the case of Teywara and Saghar, however, the number of livestock and farm size does not show a positive association. The highest number of animals are raised by farm households in the range of 2.1 to 10 jeribs of land. Farms of 10.1 to 20 jeribs in Saghar occupied the second position in animal husbandry, whereas in Teywara farms more than 20 jeribs of land own the second highest number of animals. In short, examining the distribution of livestock by 
different farm size grouping reveals that the smallest farm size groups have the least number of livestock. However, it does not necessarily follow that the largest farm size groups have the most livestock either (see Table VII.3).

To find out the extent to which the number of animal owned by households has changed over time, we have calculated the mean number of total animal per household as well as the mean number of cattle and smallstock in each district for 1973 and 1998. The result of this calculation is presented in Table VII.4. In Chaghcharan, the mean number of total animals per household was over 40 in 1973 but this has drastically fallen to about 28 in 1998 (at the time of survey). The corresponding figures for the other districts also show a sharp fall, from 23 to 16 in Saghar and from 16 to 11 in Teywara. Species-wise, the mean number of cattle fell from about 9 in 1973 to about 4 in 1998 in Chaghcharan; in Saghar from 8 to 2 and in Teywara from 5 to 1.6 . In other words $3 / 4^{\text {th }}$ of the cattle in Chaghcharan and about $7 / 10^{\text {th }}$ each in Saghar and Teywara have been "lost" between 1973-1998, most probably because of the war. The related data on the mean number of smallstock reveals a similar pattern. In Chaghcharan the mean number of smallstock decreased from 28 in 1973 to 16 in 1998, in Saghar from 13 to 10 and in Teywara from 9 to 5 . In other words, the mean number of smallstock at the time of this survey has fallen from the 1973 level (taken as base i.e.100 percent) by 59 percent in Chaghcharan, 82 percent in Saghar and 56 percent in Teywara.

Table VII.4. Summary Statistics of Livestock Ownership, 1973 and 1998

\begin{tabular}{llllllll}
\hline \multirow{2}{*}{\multicolumn{1}{c}{ Summary Statistics }} & \multicolumn{7}{c}{ District } \\
\cline { 2 - 8 } & \multicolumn{1}{c}{ Chaghcharan } & \multicolumn{2}{c}{ Saghar } & \multicolumn{2}{c}{ Teywara } \\
\cline { 3 - 8 } & & 1973 & 1998 & 1973 & 1998 & 1973 & 1998 \\
\hline Mean No of animals per household & 40.08 & 27.63 & 22.63 & 16.47 & 16.01 & 11.00 \\
No of households with no animals & NA & 0.00 & NA & 1.00 & NA & 1.00 \\
Mean No of cattle per household & 8.76 & 3.59 & 7.59 & 2.26 & 4.94 & 1.55 \\
No of households with no cattle & NA & 4.00 & NA & 12.00 & NA & 13.00 \\
Mean No of smallstock per household & 27.79 & 16.46 & 12.81 & 10.47 & 8.88 & 4.94 \\
No of household with no smallstock & NA & 13.00 & NA & 18.00 & NA & 18.00 \\
\hline
\end{tabular}

$\mathrm{NA}=$ not available 


\subsection{Livestock Productivity}

After crops, the productivity of livestock is of vital importance. Livestock productivity can be expressed in several ways. Sheep and goats are sources for essentially the same products as cattle, i.e., milk and dairy products. Besides being used for home consumption, dairy products like gee and qurut also constitute a source of income for many households. Moreover, sheep and goat produce wool to make carpets, rugs and blankets. The sheep are of two types: ordinary and qaraqul - the latter provide good hides and exquisite fur that can be sold for good price.

Meat is the other main product of all domestic ruminants. This is especially so for goats and sheep, as they have a faster reproductive rate, more rapid growth and an early age of offtake. Some farmers run commercial beef and mutton herds. However, in many households the female animals are kept for breeding and for their output, and the male animals are either slaughtered for their meat or sold for cash income. Compared to goats and sheep, cattle are rarely slaughtered for their meat. Traditionally, the majority of households slaughtered smallstock at the beginning of the winter season and stored dry meat to last through the long and cold winter months. This tradition is called Laandi. Smallstock and, to some extent, cattle are also slaughtered during the religious festivals such as Eid-i-Udha, Aashora, Mawlood-iShareef, etc.

The sex ratios are given in Table VII.5. A glance at this table indicates that, except for the cow:ox ratio, there are significantly more female animals than males in all the districts. This is in line with expectation, since animals are kept mainly for milk rather than meat. The cow: ox ratio for all the districts, however, indicates less than unity. This may be due to the fact that many farm households keep more than one bullock for ploughing.

Table VII.5. Ratio of Female to Male Animal

\begin{tabular}{lccc}
\hline Indicator & Chaghcharan & Saghar & Teywara \\
\hline Cattle, cow : ox & 0.89 & 0.59 & 0.53 \\
Sheep, ewe : ram & 2.84 & 18.79 & 38.5 \\
Goat, female : male & 6.61 & 33.25 & 19.25 \\
Poultry, hen : cock & 3.18 & 9.00 & 4.25 \\
\hline
\end{tabular}


The other relevant livestock productivity indicators are given in Table VII.6. With an average daily milk production of about 4 litre per cow, productivity is much higher in Chaghcharan; it is less by half in Teywara. The average milk production from sleep and goats is also high in Chaghcharan than in the other two districts. This may have to do with better management than with the breed type.

Using the average daily milk production and lactation period as indicators, the milk yield of a cow could be extrapolated at 641 litre in Chaghcharan, 419 litre in Saghar and 330 litre in Teywara. Milk yield from sheep and goats can also be estimated using the same method. The ratio of immature to female sheep and goats is skewed in favour of the younger animals. Put differently, for every 100 immature sheep and goat, there are 41 female sheep and 55 female goat.

Table VII.6. Index of Livestock Productivity

\begin{tabular}{lccc}
\hline Indicator & Chaghcharan & Saghar & Teywara \\
\hline Ratio of calf to female cow & 0.69 & 1.00 & 1.28 \\
Average milk/cow/day & 3.94 & 2.27 & 1.84 \\
Lactation length (month) & 5.33 & 6.05 & 5.88 \\
Ratio of immature to female sheep & 0.41 & 0.31 & 0.36 \\
Average milk/sheep/day & 2.06 & 1.31 & 1.29 \\
Lactation length (month) & 3.21 & 3.41 & 2.86 \\
Ratio of immature to female goat & 0.55 & 0.44 & 0.77 \\
Average milk/goat/day & 2.91 & 2.05 & 1.29 \\
Lactation length (month) & 3.63 & 3.70 & 3.30 \\
\hline
\end{tabular}

\subsection{Constraints to Livestock Productivity}

\subsubsection{Animal Feed}

Livestock are important sources of food and income to farm households. However, their output depends largely on the quality and quantity of feed. One of the major constraints faced 
in this regard is shortage of feed. Table VII.7 lists the months when farmers experience feed shortage and the methods they adopt to overcome this problem

Table VII.7. Feed Deficit and Coping Strategies

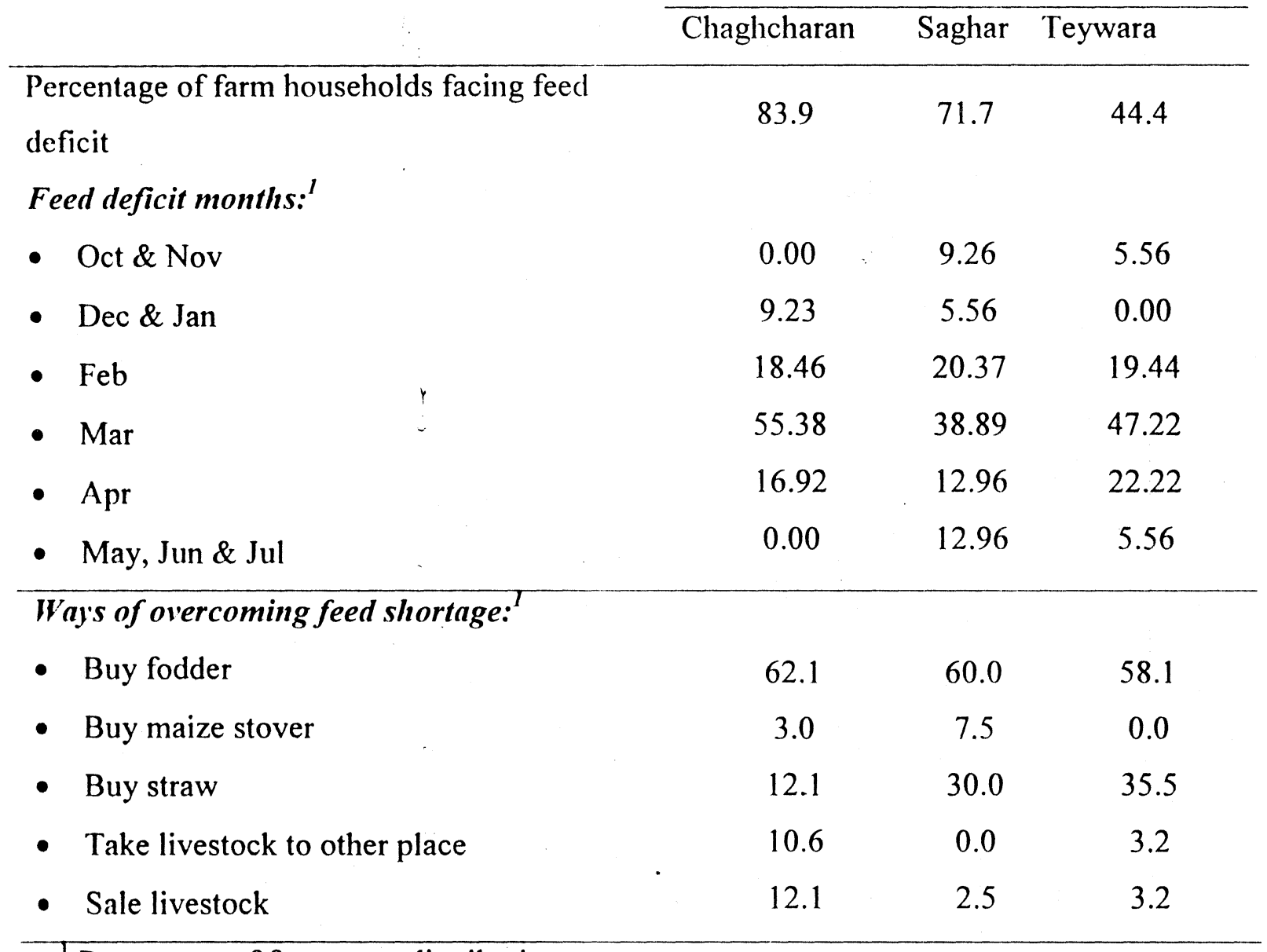

Percentage of frequency distribution

A high percentage of the farm households in Chaghcharan and Saghar face feed deficit. The problem is not so acute in Teywara, perhaps because animal numbers depleted during the war have still not recovered enough to cause pasture shortage. The number of livestock in Teywara is much less than in the other two districts (see Table VII.3).

February, March and April $y$ are the three critical months in which farmers face acute feed shortage. This is also the time when the snow is heavy and feed stocks for the winter have all been depleted. Many households stock up for the winter with dried alfalfa, grown on land allocated for this purpose. When asked about strategies for coping with feed deficit, close to 60 percent of farmers in all the three districts said they bought fodder. Many farmers also bought straw, which is cheaper, and some bought maize stover. 
The grazing pattern is a form of semi-transhumance. All the village animals are usually kept in one herd and tended by a shepherd. Each animal owner pays a share of the shepherd's wage, based on the number of animals owned. In late spring, the shepherd would graze the animals on land near the village. In the summer, the herd ventures further to land which has not been grazed on for some months. In the harsh winter, all livestock are kept in the stable and fed on various kinds of animal feed until late spring. Thus, the grazing pattern is cyclic, making the optimum use of available resources while also relieving grazing pressure in one location.

The strategy of keeping more smallstock than cattle may also be influenced by the feed shortage. Cattle are dependent on grass, which is in short supply. Smallstock, especially goats, are extremely adaptable and can forage on shrubs and leaves. It therefore makes sense to keep more of these smaller animals and use the meager feed resources.

\subsubsection{Animal Diseases}

Livestock are beset by all sorts of animal diseases. The DCA has veterinary clinics but access to the service is difficult for the poor farmers living in remote areas. The nature of vaccine also dictates that it must be kept in the prescribed environment, which means that it cannot be

Table VII.8. Common Animal Diseases in the Case-Districts

\begin{tabular}{lccc}
\cline { 2 - 4 } Diseases & Chaghcharan & Saghar & Teywara \\
\hline Blown up stomach & & $\mathrm{X}$ & \\
Extrotoxemia & $\mathrm{X}$ & $\mathrm{X}$ & $\mathrm{X}$ \\
Anthrax & $\mathrm{X}$ & $\mathrm{X}$ & $\mathrm{X}$ \\
Mange & $\mathrm{X}$ & $\mathrm{X}$ & $\mathrm{X}$ \\
Liver worms & $\mathrm{X}$ & $\mathrm{X}$ & $\mathrm{X}$ \\
Bushmaq & & & $\mathrm{X}$ \\
Hair fall off & $\mathrm{X}$ & $\mathrm{X}$ & $\mathrm{X}$ \\
Gan margai & & $\mathrm{X}$ & \\
Aman & & & \\
Fever & $\mathrm{X}$ & & \\
Lice & $\mathrm{X}$ & $\mathrm{X}$ & \\
Scales & $\mathrm{X}$ & $\mathrm{X}$ & \\
CCPP & $\mathrm{X}$ & $\mathrm{X}$ & \\
Pox & & & \\
Coldness & & & \\
\hline X & & & \\
\hline
\end{tabular}

$\mathrm{X}$ indicates the existence of a disease. 
taken to far-flung villages. In all the villages visited by the survey team, none of the animals - had been vaccinated. As a result, many kinds of animal diseases are prevalent; and these are given in the table above.

Table VII.9. Animal Mortality and Birth Rates (percentages)

\begin{tabular}{ccccl}
\hline \multicolumn{2}{c}{ Chaghcharan } & \multicolumn{2}{c}{ Teywara } & \multicolumn{2}{l}{ Saghar } \\
\hline Cow Sheep Goat Cow & Sheep Goat & Cow & Sheep Goat
\end{tabular}

\begin{tabular}{llllllllll}
\hline $\begin{array}{l}\text { Mortality rate (neo- } \\
\text { natal) }\end{array}$ & 34.3 & 12.7 & 10.4 & 9.09 & 7.4 & 3 & 10 & 4.3 & 6.6 \\
Mortality rate (other) & 24.2 & 27 & 13.5 & 1.5 & 24 & 28 & 1.5 & 89.4 & 64.5 \\
& 50 & 78 & 66 & 68 & 30 & 54 & 45 & 61 & 27 \\
\hline Birth rate & 5
\end{tabular}

With the prevalence of so many kinds of diseases, one would expect a correspondingly high rate of animal mortality. A glance at Table VII.9 confirms this apprehension. The high mortality rates for neo-natal deaths as well as for other deaths suggest the constraint farmers have to grapple with in order to increase livestock productivity. In the sample districts, where a large number of people depend on livestock for livelihood, a loss of even a single animal can cause entitlement failure. A simple package of veterinary intervention can reduce the widespread incidence of diseases and improve productivity. 


\subsection{Common Illnesses and Immunisation}

Using a combination of PRA and formal questionnaires, hea th matters were explored with the women of the sampled villages. It turned out to be that the level of health awareness is extremely poor. Their knowledge of health matters, such as clean drinking water, the cause of worms and diarrhoea is patchy, to say the least. They relied on information obtained from the local traditional birth attendants (TBAs), each other and the odd bit the men picked up from the local doctors. Most women knew the source of clean water - spring - but could not say why the water from the rivers and canals was not clean. Many women are ignorant of the health risk associated with canal and river water, despite the fact that animals used the same source and people washed their clothes and swam in it. All women knew the benefits of keeping water vessels covered in the house so as to keep flies out. The women also made a correlation between warm weather and diarrhoea, but tended to blame the heat for causing diarrhoea. A number of women said warm weather caused their breast milk go sour, which caused diarrhoea in their babies. The women also named various foods as causing diarrhoea. Intestinal worm infestations were blamed on eating too many sweets - a common belief in Afghanistan. A few women said worms come from dirt, as the local doctors told them.

The women were also asked about specific diseases in their households over the last two years. Here too, the responses are not altogether comforting. The women often could not specify the diseases that sickened or killed their relatives. They often claimed that their relatives or themselves had suffered from diphtheria or tetanus. If they had indeed suffered from either of these diseases, it is unlikely that they would have survived. It was hard for them to distinguish between coughing and pertussis, and malaria was also confused with general fever. In addition, despite being repeatedly asked to refer only to diseases within their own households and within the last two years, they frequently included their neighbours, friends and extended family members and some even referred back for cases years ago. The women did not have any idea of answering questions, particularly so directly. They also didn't appreciate the importance of giving accurate information. 
Lack of health awareness is exemplified by fact that in the warm months diarrhoea and eye infections are prevalent throughout the villages and in the winter acute respiratory tract infections cause severe illness. The eye infections are mostly conjuctvities, caused by lack of hygiene. The women said those who sought medical help faired better; those who didn't went blind. Tetracycline eye ointment is available in the city centres, but not in the villages. Rising cost of medicines and doctors' fee restrict early treatment. Prescriptions invariably include several unnecessary drugs which doctors use to legitimise their charge (doctors work on a commission basis with the pharmacists).

The women recognised the link between vaccines and improved health in children and said, the men in their communities also encourage them to get their children vaccinated. Nevertheless, vaccine campaigns are infrequent and often only for one or two of the diseases, i.e., tetanus or polio. In Zargaron, Saghar district, the local school teacher's wife, although illiterate, has been taught basic health and hygiene practices by her husband, and she has been employed by vaccination teams to vaccinate women and children. In Zargaron, the survey team has met the only literate woman during the course of the survey. She has completed eight years of schooling in Pakistan. Both these women would be useful contacts for NGOs.

In one other village, the survey team visited a family and observed a newly born baby fed lard. The mother considered colostrum (the mother's first milk) harmful to the baby. The mother also refused to wash or mobilise for ten days post-delivery lest it be harmful to her health. The baby's cord had been smeared with a substance of fat and ash and had been tied with a dirty rag end. It was imagined that its cord had been cut with whatever was nearest at hand. Many of these traditional practices could be overcome through basic health education programme.

\subsection{Nutrition of Women}

The women thought it hilarious the survey team should be interested in what they ate. Their diets appeared dismal on paper. Most of the women claimed to eat bread alone and tea (without sugar) twice a day, the mid-meal supplemented with buttered milk, dugh, dry cheese, qurut, milk or yoghurt. Very few ate meat and rice. In Chaghcharan district centre, a shopkeeper said to the survey team that he has not sold any rice to the locals this year. The women said they ate meat and rice only at weddings, funerals or special events. Often the 
practice is that the men and older boys eat first and wornen scramble for leftovers, if any; otherwise their diet is constituted of bread and tea, in most cases. A number of women said that they use wild sage instead of tealeaves, for they could not afford to buy tealeaves. A clear indication of the extent of food shortage in the villages is that the survey team was unable to find solid food and vegetables and had to live on eggs, yoghurt, dry bread and tea.

\subsection{Child Feeding}

Without exception, all the women breastfed their babies. Most of them had been advised by their mullahs to breast feed for two years, as suggested in Hadiees (Prophet Mohammed, peace be upon him, sayings). Women attribute inadequate breast milk, exhaustion and pregnancy as the major causes for an early weaning. All felt that breastfeeding while pregnant would cause the child physical and mental health problems, i.e. insanity, weakness and diarrhoea. Many also said they stopped breastfeeding while pregnant because it was too hard on them to be pregnant and breast feed at the same time.

Most women gave their babies solid food around one year of age. Milk was usually supplemented with solid food after four months of age, not because the women recognised the need to give supplementary feed, but because by this time the mothers' milk supply had already diminished. The survey team noticed a number of babies suffering from malnutrition due to incorrect weaning. Many women abruptly withdrew babies from breast and put them straight into solid food. This practice resulted in the babies developing diarrhoea and losing weight. In addition the babies are mostly, fed two or three times a day. Because of the babies initial aversion to new food they are only given bread or animal milk. The concept of feeding a baby frequently, with small amount and building its tolerance to different foods, textures and flavours is completely unknown to many of the mothers.

\subsection{Disabilities}

There were few disabled people who claimed to be members of the sampled households. Land mines that claimed many amputees in other districts are, thankfully, almost unknown. Most disabilities seemed to be from congenital causes, polio, or accidents but not from war related injuries. In Khairkunak, Saghar district, there were two women from two separate households whose children all suffered from congenital deformities, causing paraplegia and 
sub-normal intelligence. The other women said it was caused because the women breastfeed the children while pregnant. Again traditional beliefs and taboos are abound.

\subsection{Common Illnesses and Immunisation}

The common diseases in all three districts are tuberculosis, bronchitis, hepatitis, diarrhoea, measles, theumatism, polio, typhoid and malaria. Diarrhoea and dysentery affect many people, especially during the summer. While households do not have a clear idea about the causes of diarrhoea, they nonetheless are aware of the sources of treatment (Table VIII.1). More than 77 percent of the sample households in Chaghcharan, about 74 percent in Saghar and over 59 percent in Teywara said they would consult a physician for treatment. A very large percentage of the households are also familiar with ORS - about 97 percent of those interviewed in Chaghcharan indicated their familiarity with ORS. The corresponding figures for Teywara and Saghar are also very high - over 95 percent. ORS could be obtained for free from clinics (only in Chaghcharan) or purchased from local bazaars. Much of the ORS is obtained from the bazaars, however. In Saghar and Teywara, all the households purchase ORS from local bazaars; in Chaghcharan, only 17 percent of the households obtained ORS freely from the clinics. ORS is expensive to most households and also hard to come by in the remoter villages. Instead, many households use local herbs to cure diarrhoea.

Table VIII.1. Treating Diarrhoea (percentage of households)

\begin{tabular}{llccc} 
& & Chaghcharan & Saghar & Teywara \\
Consulting a & & 77.41 & 73.68 & 59.09 \\
$\begin{array}{l}\text { Physician } \\
\text { Familiarity with ORS }\end{array}$ & & 96.78 & 95.0 & 95.45 \\
Source of ORS & - Clinic & 16.67 & 0.0 & 0.0 \\
& - Bazaar & 83.3 & 100.0 & 100.0 \\
\hline
\end{tabular}

Children in the study area suffer from poor health and many die from measles, diarrhea and polio. Afghan Red Crescent, the Ministry of Public Health and UNICEF provide immunization services in all three districts. Vaccines have made a marked difference in lowering child mortality. In areas where vaccines are not available, child mortality rate is high and the vast majority of women have lost at least a child. A few villages have received polio vaccines as part of the national polio eradication campaign by UNICEF last year. In 
more accessible areas women and children have received other vaccines but only in the last 2-3 years and even then not the full course. Table VIII.2 shows child immunisation coverage among the sampled households. As the table indicates, the perrentage of immunised children is considerably low in all the districts - 32 percent in Chaghcharan, 43 percent in Teywara and 55 percent in Saghar. The majority of the children, up to 68 percent in the case of Chaghcharan, are not immunised. None of the children in Chaghcharan and Teywara are immunisied against measles and DTP, and of Teywara against Tetanus. The percentage of immunised children against other diseases is also very low.

Table VIII.2. Child Immunisation in the Case-Districts (percentage)

\begin{tabular}{lcccccc} 
& Immunised & BCG & DTP & Polio & Tetanus & Measles \\
\hline Chaghcharan & 32.2 & 3.2 & 0.0 & 22.5 & 6.4 & 0.0 \\
Teywara & 43.5 & 26.1 & 0.0 & 34.8 & 0.0 & 0.0 \\
Saghar & 55.0 & 50.0 & 10.0 & 25.0 & 10.0 & 5.0 \\
\hline
\end{tabular}

\subsection{Child Loss and Fertility Analysis}

Some mortality and fertility data were also collected during the survey. Though the "correct" levels could not be established with confidence from the daia, an attempt is made here to present a picture that approximates the reality. The relevant information is summarised and presented in Table VIII.3. This table indicates the expected high level of child loss and childbirth in all three case-districts. Saghar district, with a mean number of 3.25 children died per interviewed woman, has the highest level of child mortality (in fact the women of this district have lost more than 40 percent of their children ever born). The corresponding figures for Teywara and Chaghcharan are 2.74 and 2.52, respectively. Put differently, women in these two districts have lost 37 and 38 percent, respectively, of their children born alive. The mean number of male child loss is higher than the female in all the three districts. A possible reason for this could be that males, especially in comparatively higher ages, were more likely to have been involved in the conflict. The high number of child loss among the women of higher age group is consistent with expectation. 
Table VIII.3. Birth and Child Loss Related Indicator

a) Chaghcharan

\begin{tabular}{|c|c|c|c|c|c|c|c|c|c|c|}
\hline \multirow[t]{3}{*}{$\begin{array}{l}\text { Age of } \\
\text { Women }\end{array}$} & \multirow[t]{3}{*}{$\begin{array}{l}\text { Number o } \\
\text { women }\end{array}$} & \multicolumn{2}{|c|}{$\begin{array}{l}\text { Number of } \\
\text { pregnancies }\end{array}$} & \multirow{3}{*}{$\begin{array}{l}\text { Aver- } \\
\text { age No. } \\
\text { of live } \\
\text { births }\end{array}$} & \multicolumn{6}{|c|}{ Survival status of live born children } \\
\hline & & $\begin{array}{l}\text { miss- } \\
\text { carri- }\end{array}$ & $\begin{array}{l}\text { Live } \\
\text { birth }\end{array}$ & & \multicolumn{3}{|c|}{$\begin{array}{l}\text { Mean number of children } \\
\text { still alive }\end{array}$} & \multicolumn{3}{|c|}{$\begin{array}{l}\text { Mean number of children } \\
\text { died }\end{array}$} \\
\hline & & ages & & & Total & Male & Female & Total & Male & Female \\
\hline $15-24$ & 6 & 3 & 22 & 3.67 & 2.67 & 0.50 & 2.17 & 1.00 & 0.67 & 0.33 \\
\hline $25-34$ & 10 & 6 & 63 & 6.30 & 4.60 & 2.70 & 1.90 & 1.70 & 1.10 & 0.60 \\
\hline $35-45$ & 4 & 0 & 22 & 5.50 & 2.75 & 1.25 & 1.50 & 2.75 & 2.25 & 0.50 \\
\hline $46+$ & 11 & 13 & 100 & 9.09 & 5.09 & 2.36 & 2.73 & 4.00 & 2.18 & 1.82 \\
\hline Total & 31 & 22 & 207 & 6.68 & 4.16 & 1.97 & 2.19 & 2.52 & 1.55 & 0.97 \\
\hline
\end{tabular}

\section{b) Saghar}

\begin{tabular}{|c|c|c|c|c|c|c|c|c|c|c|}
\hline \multirow[t]{3}{*}{$\begin{array}{l}\text { Age of } \\
\text { women }\end{array}$} & \multirow{3}{*}{$\begin{array}{l}\text { Number } \\
\text { of } \\
\text { women }\end{array}$} & \multicolumn{2}{|c|}{$\begin{array}{l}\text { Number of } \\
\text { pregnancies }\end{array}$} & \multirow{3}{*}{$\begin{array}{l}\text { Aver- } \\
\text { age } \\
\text { No. of } \\
\text { live } \\
\text { births }\end{array}$} & \multicolumn{6}{|c|}{ Survival status of live born children } \\
\hline & & \multirow{2}{*}{$\begin{array}{l}\text { miss- } \\
\text { carri- } \\
\text { ages }\end{array}$} & \multirow[t]{2}{*}{$\begin{array}{l}\text { Live } \\
\text { birth }\end{array}$} & & \multicolumn{3}{|c|}{$\begin{array}{l}\text { Mean number of } \\
\text { children still alive }\end{array}$} & \multicolumn{3}{|c|}{$\begin{array}{l}\text { Mean number of } \\
\text { children died }\end{array}$} \\
\hline & & & & & Total & Male & Female & Total & Male & Female \\
\hline $15-24$ & 1 & 0 & 2 & 2.00 & 1.00 & 1.00 & 0.00 & 1.00 & 0.00 & 1.00 \\
\hline $25-34$ & 9 & 9 & 59 & 6.56 & 4.89 & 2.55 & 2.33 & 1.67 & 0.89 & 0.78 \\
\hline $35-45$ & 5 & 2 & 42 & $8.40^{\circ}$ & 4.40 & 2.20 & 2.20 & 4.00 & 2.00 & 2.00 \\
\hline $46+$ & 5 & 5 & 58 & 11.60 & 5.80 & 2.80 & 3.00 & 5.80 & 4.00 & 1.80 \\
\hline Total & 20 & 16 & 161 & 8.05 & 4.80 & 2.45 & 2.35 & 3.25 & 1.90 & 1.35 \\
\hline
\end{tabular}

\section{c) Teywara}

\begin{tabular}{|c|c|c|c|c|c|c|c|c|c|c|}
\hline \multirow[t]{3}{*}{$\begin{array}{l}\text { Age of } \\
\text { women }\end{array}$} & \multirow{3}{*}{$\begin{array}{l}\text { Number } \\
\text { of } \\
\text { women }\end{array}$} & \multicolumn{2}{|c|}{$\begin{array}{l}\text { Number of } \\
\text { pregnancies }\end{array}$} & \multirow{3}{*}{$\begin{array}{l}\text { Aver- } \\
\text { age } \\
\text { No. of } \\
\text { live } \\
\text { births }\end{array}$} & \multicolumn{6}{|c|}{ Survival status of live born children } \\
\hline & & \multirow{2}{*}{$\begin{array}{l}\text { miss- } \\
\text { carri- } \\
\text { ages }\end{array}$} & \multirow[t]{2}{*}{$\begin{array}{l}\text { Live } \\
\text { birth }\end{array}$} & & \multicolumn{3}{|c|}{$\begin{array}{l}\text { Mean number of } \\
\text { children still alive }\end{array}$} & \multicolumn{3}{|c|}{$\begin{array}{l}\text { Mean number of } \\
\text { children died }\end{array}$} \\
\hline & & & & & Total & Male & Female & Total & Male & Female \\
\hline $15-24$ & 2 & 1 & 8 & 4.00 & 2.00 & 1.00 & 1.00 & 2.00 & 0.5 & 1.5 \\
\hline $25-34$ & 9 & 5 & 61 & 6.78 & 4.00 & 2.00 & 2.00 & 2.22 & 0.89 & 1.33 \\
\hline $35-45$ & 5 & .5 & 55 & 11.00 & 8.00 & 5.00 & 3.00 & 3.00 & 1.60 & 1.40 \\
\hline $46+$ & 7 & 4 & 55 & 7.86 & 4.00 & 2.57 & 1.43 & 3.86 & 2.14 & 1.72 \\
\hline Total & 23 & 15 & 179 & 7.78 & 4.70 & 2.74 & 1.96 & 2.87 & 1.39 & 1.48 \\
\hline
\end{tabular}


The level of high child mortality could also be expressed by the data presented in the table below.

Table VIII.4. Percentage Distribution of Interviewed Women by Number of Child Loss

\begin{tabular}{|l|l|l|l|}
\hline $\begin{array}{l}\text { Number of child } \\
\text { loss }\end{array}$ & Chaghcharan & Saghar & Teywara \\
\hline 0 & 9.70 & 10.00 & 35.11 \\
\hline 1 & 35.48 & 25.00 & 8.69 \\
\hline 2 & 16.12 & 10.00 & 21.73 \\
\hline $2>$ & 38.70 & 55.00 & 34.47 \\
\hline
\end{tabular}

Table VIII.4 shows that 55 percent of the interviewed women in Saghar have lost more than two children. Child mortality in Chaghcharan and Teywara is also considerably high. The percentage of women who have lost one and two children is also high in all the districts. Only about 10 percent of the sampled women in Chaghcharan and about the same proportion in Saghar have not experienced child loss; the corresponding figure for Teywara is comparatively high ( 35 percent).

Malnutrition, various types of epidemics and unhygienic conditions account for the high level of child mortality in this region. Births are either attended by untrained traditional birth attendants, TBA, (97 percent in Chaghcharan, 90 percent in Saghar and 77 percent in Teywara) or by neighbours ( 3 percent in Chaghcharan, 10 percent in Saghar and 18 percent in Teywara), or even by family members ( 5 percent in Teywara). This practice is likely to have increased the level of neo-natal mortality rate in the study population, leading to the increase in total child loss.

The level of fertility in the study area is also considerably high. Table VIII.3 shows that the average number of children born alive is 8.05 in Saghar, 7.78 in Teywara, and 6.68 percent in Chaghcharan. The high fertility level of the study population is not peculiar, because of two main reasons: first, high fertility is a fundamental adjustment to high mortality and that high fertility is necessary for group survival when mortality is high. When infant and child mortality is high, this consideration becomes important, because a large number of children increases the chances of some surviving to adulthood. Second, in a social structure as our study population, children have a great economic, social, and cultural as well as religious values. They become economically useful by the age of six or seven, and therefore are not 
economic liability for their parents but economic asset. Thus, low level of living, lack of education, low status of women, preference for sons, etc. all lead to the growth of family size.

\subsection{Drinking Water and Sanitation}

Drinking water and sanitation is another health concern of the study population, especially for the women. Very few households have wells in their compounds. The vast majority share an outside water source with their neighbours. The main sources of drinking water are given in Table VIII.5. It is apparent that the population is exposed poor health. The overwhelming majority of the households in all the districts get water from rivers and canals - 59 percent in Chaghcharan, 77 percent in Saghar and nearly half the population in Teywara. None of the sampled households have access to covered wells. The proportion of those getting drinking water from spring is low - 26 percent in Chaghcharan and only 8 percent each in Saghar and in Teywara. Similarly, only a negligible percent of the people - that is also in one village in Chaghcharan - have access to kareeze water. It should be mentioned though that spring and kareeze water is not necessarily clean.

Table VIII.5. Percentage Distribution of Households by Source of Drinking Water

\begin{tabular}{|l|l|l|l|}
\hline Source & Chaghcharan & $\begin{array}{c}\text { Saghar } \\
\cdot\end{array}$ & Teywara \\
\hline Canal & 2.42 & 77.47 & 48.53 \\
\hline Spring & 25.93 & 7.84 & 8.46 \\
\hline Kareeze & 2.02 & 0.00 & 0.00 \\
\hline River & 58.53 & 0.00 & 20.22 \\
\hline River, Spring & 11.10 & 0.00 & 0.00 \\
\hline Canal, Spring & 0.00 & 14.69 & 1.83 \\
\hline Kareeze, Canal & 0.00 & 0.00 & 18.38 \\
\hline Covered well & 0.00 & 0.00 & 0.37 \\
\hline Uncovered well & 0.00 & 0.00 & 2.21 \\
\hline \multicolumn{1}{|c|}{ Total } & 100.00 & 100.00 & 100.00 \\
\hline
\end{tabular}

Distance to the sources of drinking water also seems to be a problem for the study population; it varies from a few minutes to an hour or more walk in each direction, depending on the season. In some villages, the communal water source dries up and, for several months, people are forced to walk long distances to get water (Table VIII.6). 
Table VIII.6. Percentage Distribution of Households by Time Required to Fetch Water

\begin{tabular}{|l|l|l|l|}
\hline Time required to fetch water & Chaghcharan & Saghar & Teywara \\
\hline Less than 10 minutes & 29.00 & 65.00 & 65.20 \\
\hline 10 to 20 minutes & 9.75 & 10.00 & 4.30 \\
\hline 20 to 30 minutes & 32.25 & 20.00 & 26.10 \\
\hline More than 30 minutes & 29.00 & 5.00 & 4.30 \\
\hline
\end{tabular}

In Chaghcharan, more than 61 percent of the respondents require, on average, over 20 minutes to collect water from the respected sources. The corresponding time required for Saghar and Teywara are 25 and 30 minutes respectively.

Besides drinking water, households need water for their domestic animals. People in all three districts, as observed by the survey team, use the same water source for their animals. All the village residents, without exception, are responsible for the improvement and maintenance of water sources.

The lack of adequate and clean water and hence poor hygienic conditions account for many cases of skin and water born diseases, such as dysentery, diarrhoea and typhoid among the study population.

\subsection{Sanitation}

Only few households have pit latrines; the vast majority of the people use the open space. Only 11 percent in Chaghcharan, 26 percent in Teywara and 30 percent in Saghar have access to latrine. Almost all the toilets are located outside the compound and are not covered. Somewhat surprisingly, the Afghan Red Cross Society clinic in Chaghcharan did not have toilet facilities either. Patients and staff relieve themselves outside, in the open space.

Most households have no bathing facilities and there are no public bathe houses (banned for women now anyway under the government). Women reluctantly confessed that they bathed outside the compounds under night cover. Only a few, very old, women said they dared bathe in the river and then with great vigilance. 
Table VIII.7. Sanitary Practices (percentage)

\begin{tabular}{l|cccccc}
\cline { 2 - 7 } Place of throwing waste & \multicolumn{2}{c}{ Chaghcharan } & \multicolumn{2}{c}{ Teywara } & \multicolumn{2}{c}{ Saghar } \\
\cline { 2 - 7 } & $\begin{array}{c}\text { Waste } \\
\text { disposal }\end{array}$ & $\begin{array}{c}\text { Water } \\
\text { disposal }\end{array}$ & $\begin{array}{c}\text { Waste } \\
\text { disposal }\end{array}$ & $\begin{array}{c}\text { Water } \\
\text { disposal }\end{array}$ & $\begin{array}{c}\text { Waste } \\
\text { disposal }\end{array}$ & $\begin{array}{c}\text { Water } \\
\text { disposal }\end{array}$ \\
\hline $\begin{array}{l}\text { Anywhere outside the } \\
\text { house }\end{array}$ & 97 & 97 & 83 & 83 & 95 & 95 \\
$\begin{array}{l}\text { Specified place outside the } \\
\text { house }\end{array}$ & 3 & 3 & 17 & 17 & 5 & 5 \\
\hline
\end{tabular}

And all the women dispose of used water and garbage anywhere outside the house, and none gathered waste in one area to either burn or apply on fields as compost. Only a very negligible proportion of the sampled households have separate soaking pits (Table VIII.7). 


\section{PART IX. MANAGEMENT OF COMMON PROPERTY RESOURCES

\subsection{Forest Resources}

Even before the war that ravaged the country, forestland accounted for a mere 4 percent of the total land use in the case-districts, and this was entirely in Chaghcharan (see Table II.2). The Forestry Department looked after the trees and fined trespassers. With the collapse of government institutions that control has gone and the trees have disappeared as well. Buta (brushwood) and animal dung are now the main fuel sources. Kerosine is used only for lighting the house. The price of kerosine is very high and not affordable in large quantities for many households. The amount of buta needed for cooking, baking and heating by an average household is estimated at 20-5ü donkey loads annually (AAD 1995). Besides animal dung, fruit tress, mountain trees sucl, as pistachios and almond are also cut and used for fuel. This has resulted in the extensive deforestation and denudation of the mountains. People complain of severe floods and mud slides in recent years, but are not aware of the effects their actions on the eco-system. Every year, floods wash irrigated lands along rivers, fill up irrigation canals and damage kareezes and springs. Owing to the depletion of natural resources, people are spending more time in collecting firewood.

With the disappearance of communal forest resources, all the trees are now owned and operated by individuals. The trees privately owned are more or less intact, as villagers only collect bushes and small branches for fuel. There is not much of a market for timber locally. The restricted access to roads and the prohibitive cost of transporting timber to commercial markets combine to ease the pressure on forest resources. However, as the stock of bushes and firewood continues to diminish, one can expect the cutting of trees to rise to fill the gap. Thus, renewal of the resource base of bushes becomes even more vital for sustainable use of trees.

\subsection{Grazing Areas}

Typifying the agro-pastoral farming system is the proportion of pastureland. In 1973, pastureland accounted for over $56 \%$ of the total land in the three case-districts. It was 
nearly half the area in Teywara and Saghar districts (refer to Table II.2.). By then, the - livestock population was also high; but offtake rate was significant too. A study by Afghanaid in 1995 found that a record number of, up to two million, animals were sold annually at the Chaghcharn Ganji (livestock market) before the war in 1978 (AAD 1995). It is difficult to determine the present stocking level and the extent of overgrazing, but the PRA exercise clearly indicates that feed shortage is a constraint for rebuilding the depleted herd. Agriculture is also encroaching on to grazing lands. When there is sufficient water, people cultivate common grazing lands. In Saghar there is little livestock activity now because of lack of grazing land.

Whatever pastureland is available it is managed through a communal system of land tenure, which has remained virtually unchanged over the years. Variations between different communities are slight. In all the villages sampled, grazing land is owned collectively by the community, and no fee or royalty is charged for grazing rights to the pasture. All the animals belonging to villagers are herded together and looked after by shepherds. Each villager contributes towards the shepherds' salary in proportion to the total number of animals. One herder might tend between 200 and 300 animals, consisting of cows, sheep and goats. Horses and donkeys, also present in large numbers, are usually kept in the stables and not allowed to graze freely.

The shepherd applies grazing rotations. Animals are grazed close to the village in late spring, taken further afield in the summer, and confined to the stables in winter. However, grazing rotations are not rigid or formal. Most villagers claimed that the grazing areas are too small to manage in this way. Thus, one sees that the communal rangeland under considerable grazing pressure. Even in Chaghcharan, where there is more rangeland than elsewhere, the high number of animals leads to the same predicament.

Common resources often lead to conflict among users, especially when the institutions are under stress of some sort. The PRA shows that roughly $67 \%$ of villages experienced conflicts over grazing areas. Most of these conflicts tended to be with kutchi nomads who cross the area with their herds and let their animals graze indiscriminately. If the animals graze on agricultural land, the kutchis are liable for a fine. Sometimes the villagers make arrangement with the kutchis or else they just bar them from using the common land. Such drastic action 
by the settled community has in some cases led to armed conflict with the transgressors kutchis.

Rangeland also serves another purpose - a source of fuel. All villagers are free to collect bush for firewood from the communal land, a chore usually done by women. The increase in population means that there are not enough bushes to go around these days. Humans as well as animals are rapidly depleting the current stock. Some rules need to be enforced to limit the free access to bushes. Afforestation activities also need to be formalized in order to encourage sustainable practices by villagers and build up a reserve of timber and firewood. 


\section{PART $X . \quad$ OPPORTUNITIES AND CONSTRAINTS}

The preceding sections have sought to provide detailed information, both at the household and community level for the three sampled districts. The objective in this section is to summarise the key findings of the survey and to assess opportunities and potential constraints for programme activities by agencies that have participated in the survey - Afghanaid, Christian Aid, Coordination of Humanitarian Assistance, and International Assistance Mission. Programme strategies are also discussed and the merit of co-ordinating interventions is justified.

\subsection{Major Findings}

It is apparent that agriculture is the key sector upon which households depend. The survey, however, shows that agriculture is not developed. Low input-output and traditional mode of technology characterises farming and animal husbandry. One of the main constraints to crop and horticultural production is the lack of an irrigation infrastructure, which renders much of the area uncultivable. The population is highly dependent on rainfed land for agriculture production. Timely rainfall and high sowing rate of up to $50 \% \mathrm{~kg} / \mathrm{jerib}$ (recommended average is $27 \%$ ) are critical to avoid crop failure. Up to $90 \%$ of the sampled households cxperience food deficit cluring the "hungry seasons" - the pre-harvest months - as they cannot produce enough to meet their requirement. In the spring, prices go up and many households face entitlement failure. This is also the season when the kutchi nomads arrive to the villages and purchase wheat in competition with the local population. Since many households are food deficit, a large proportion of their income, up to 46 percent, is spent on wheat purchase annually; in the case of small farm groups, this proportion is even higher, nearly 50 percent.

Agriculture, if addressed with the right strategy, can have far-reaching impact on a multitude of problems the people of Ghor experience. A major intervention would be the reconstruction of irrigation systems destroyed and damaged during the war. This would involve the construction of small "canals, intakes and weirs. The development of the irrigation systems would allow land to be utilized more intensively; multiple cropping may also be a possibility. Area expansion is not a viable option for agricultural inprovement, primarily because there is little land left uncultivated. There is not much land left as fallow either. 
Another intervention would be improved technology in the fom of seed, fertilizer and extension advice. Improved inputs would increase productivity and improve the food balance of houscholds. The local wheat varieties sown by the bulk of the population are susceptible to rust and diseases, and productivity is low, about 32 seers per jerib. This level of productivity compares very unfavourably with that ohtained by small farmers even in Badakhshan, about 45 scers/jcrib (SCA-ASA, 1992:4), in Wardak (( hak) about 44 secrs/jerib and in Nuristan (Kamdish) about 41 seers/jerib ( $\triangle \wedge D$ )-MRII, 1982:52). The local varieties are also contaminated and every year farmers face a dearth of problem in finding clean seed. It should be mentioned that most improved wheat varietics demand fertiliser, pesticides and relatively more water that many houscholds do not have access to. Therefore, less high yielding but more robust varietics, adapicd to low imput and mountain conditions, would he the preferred seed.

Besides improved seed, there is scope for improving agriculture by on-farm extension activities. In the case of Afghanaid, this can be implemented th:ough "village organisations". Young men who seasonally migrate to urban areis can be cmployed as "farmer-extension workers" and deployed in their respective villages. This is a viable and sustainable strategy, for it builds the capacity of the communities.

Other factors suggest that efforts made in the cropping sector cim have greater chances of bearing fruit. One is the absence of poppy cultivation, which means that resources and energies can be fully directed to crop and horticulture production. The distribution of property rights and land tenure is also not so polarised, with a majority of the farmers identifying themselves as owners or owners-cum-sharecroppers. This works as an incenlive. and would ensure that efforts made in this regard benefit the smallholders who occupy the poorest segment in the communities.

Livestock constitute a major part of the economy, generating a large proportion of houschold income, particularly for womenfolk who sale animal products to carn cash. In some areas it is probably of higher importance than cropping. Apart from the settled population, the pastures are used by the nomads who seasonally migrate to the mountains on the onset of spring and return to lower lying fields. The vast alpine pastures use to be grazed by flocks and herds of livestock from neighbouring provinces of Kandahar, Herat. Nimroz, Faryab and Badghis. Herders brought their animals to graze for $4-5$ months 
(April -. September). Over the past twenty years, however. the pastures have diminished. more so from the collapse of traditional grazing systems than from grazing pressure per sc. A major problem faced seasonally is therefore shortage of feed in the winter months. when livestock are stable-fed. Improvements delineated in the agriculture sector would enhance crop production and increase crop residues available for livestock. Crop rotation, if feasible, should enable famers to grow some alfalfa and clover, both good sources of animal feed.

Livestock production is also constrained by lack of veterinary services. The services given by the Dutch Committee for Afghanistan have limited coverage. Funther veterinar services are therefore needed to reach outer lying villages in particular. and this is best approached through a programme of training local people and assisting them with vaccines and medicines - more like the BVW programme rum by $\Lambda$ fghanaid in Badakhshan. The provision of veterinary services will go a long way in reducing animal mortality and increasing productivity in the case- districts. I ack of vetcrinary service results in a very high animal mortality rate. With its large number of animals, Chaghcharan is the most in need of veterinary services.

Poverty in Ghor is rampant, and it manifests in many ways lack of hasic services such as health and education, lack of access to markets, food insccurity. etc. No doubt farm houscholds are worse-off now than they were before the war. Poverty is an ahsolute phenomenon, and great disparities between households and districts are not evident. The deterioration of social and productive assets has exacerbated vulncrability and sufferin!: across the board. There is only one hospital in the entire province and while most districts have a clinic, they are ill-cquipped to deal with mounting demand. Health cducation appcars to be as important as clinical service. Lack of clean drinking water is a major health issue in Ghor. Drinking water is obtained from rivers, springs and irrigation canals. and the people are unaware of the health risks associated with using such water. The profound ignorance regarding the basic principles of health and hygiene resulted in a profusion of casily. preventable diseases in the community. Although women did not list improved sanitation as a need, the introduction of latrines and waste disposal would assist in reducing infections in the community. In addition, simple bathing facilities would help women (and families) mect their hygiene needs, particularly now that the Taliban have hanned women from goin! w public bathhouses. I ack of health awareness, poor sanitation. malnutrition and unclean water 
all exacerbate the health risk of the population. The level of child loss is very high, 37 to t() percent of the children die. This can be attributed to preventable discases. such as measles, tetanus, polio and tuberculosis. Predictably, birth rates are also high the mean number of children born ranges from 7 to 8 . All women depend on untrained TBAs during delivery Health education and training of traditional birth attendants (TBA) can benefit the women.

Opportunities to work with women appear to be far better in (Gh)r than anywhere else in the south and west of Afghanistan. There is immense scope for improving the handicraft industry, especially carpet and gilim weaving. The women are alrcady skilled in many aspects of the work. They have asked NGOs to market and sell their products, but this is not sustainable. Vocational training can however be given in design and dying to add value to the carpets they make. Support could also be given to find a market in Ilerat or to form cooperatives to deal with independent buyers. A micro-credil/saving programme could go at long way in increasing incomes and alleviating some of the grinding poverty. Introducing the women to the concept of savings in particular is important, for it reduces their dependence on lenders every season when food stocks dwindle. The survey indicated that most houschoids borrow money to purchase basic food items. Seasonal migration of the men to neighbomin! provinces and countries in search of employment and the salc of firewood all point to the fiet that income is meager and people employ various coping mechanisms to carn a living.

Ghor can be accessed from Herat and Kabul. However, logistics are difficult and travel is time consuming. Between November and April, the province is not accessible due to snow. Within the province al! the roads are rough and transportation costs are very high. Often the spring floods damage the roads and, in the absence of pubic and or local initiative to maintain them, most of the villages in the districts are not accessible by vehicle. Deficient physical infrastructure restricts the flow of goods and creates pockets of food deficit and surplus areas. Road improvement could thus have a positive impact on the local economy, for it would enhance trade and inter-regional flow of goods as well as provide access to health and education services. It would induce markeling and lower commodity prices. Pcople in Saghar, for example, are keen to sale their dry fruit in Herat and carn better return but are prevented from doing so because of lack of transport. 


\subsection{Recommendations}

Ghor is an attractive proposition to aid agencies committed to a long-term development programme. It is by far the poorest and most neglected province in the country. Both in terms of number of aid agencies and the diversity of programmes, the province is vastly under-served. With the exception of some veterinary and health programmes, some run by Afghan N(jOs, there is hardly an intervention that aimed at improving the productive infrastructure and capacity building for a sustainable development. In order to tackle rural poverty and ceprivation, aid agencies have to focus on long-term development programme. This in turn demands a coherent strategy of aid delivery. It also demands cooperation amongst NGOs so that impact can be maximised.

Ghor's geographic location is such that it is contiguous to other poor provinces. Programme activities there can link up with Bamiyan and Badghis to cover what may be regarded as a "poverty zone". This zone is known for its relative isolation, poor infrastructue and food insecurity, exacerbated by the protracted warfare. Ghor thus offers a distinct oplortunity for agencies looking to expand their programme in the region.

As current convention says, a sustainable grass-root development can create an environment for peace, and the region offers a fertile ground for this. A sustainable develoment can be achieved through enhanced productivity, efficient management of the conmon property resources and building indigenous institutional capacity. Enabling communiti 3 this way can immensely contribute toward lasting peace.

On account of agency "specialisation", Ghor offers opportunities for all the fur agencies that have participated in this survey. The survey has identified a plethora of need that are beyond the ability of a single agency. Managerial and resource constraints apart, a ncies have their own "area of strength". In order to optimise impact and address the develop tent problem, the agencies need to develop a strategy that would enable them complement 4 th other in skills and resources. The usual practice has been for each agsncy to determine ts niche and then intervene independently. However, experience shows that a coordinated: proach by NGOs, employing a complementary and common strategy stands a much better c ance of addressing poverty on a sustainable manner. Afghanaid could, for example, use an mended version of its community development programme, implemented through democra ally elected village 
organisations (VOs) and supported by productive infrastructure development, while other agencies could deliver social services of health and education, and various income generating activities, through the VOs. It is particularly important to design programmes to address the development problems on a long-term basis. Poverty is widely entrenched and relief would only be a palliative with no long-term positive impact. The report urges $\mathrm{AAD}, \mathrm{EO} / \mathrm{CA}, \mathrm{IAM}$, CHA and other NGOs to develop a common strategy. It recommends that EO/CA and Afghanaid take the lead and initiate discussions with the view to reaching tentative agreements with the other agencies.

From a programming point of view logistics may pose a major constraint on aid operations in the province - particularly for agencies with not foothold in the region. Opening a joint regional office in Herat shared by all the agencies involved, could be cost effective. Coordination of activities and monitoring could also be enhanced if agencies operated from one office. AAD in particular would be over-stretched if it tried to service programme from its head office in Peshawar.

\subsection{Operational Restrictions}

Jnlike in other provinces of Afghanistan where the local authorities exert pressure and, in ؛ome cases even interfer directly on programme matters, operational restrictions are not evident in Ghor. Although the Taliban are in power, they do not seem to have a major irfluence on the population. The survey team was able to interview women and to organize group discussions with women. It was even possible to have a male interpreter during the group discussions with the women. The villagers, mullahs and shmra leaders were open and welcoming. They showed particular interest in programmes focused on women. They also plaaded with the team to help them rebuild their shattered economy, and confirmed their readiness to co-operate in any possible way.

\subsection{Post-Script}

Since conducting this survey in July, the political balance has shifted decisively towards the Taliban, who now conirol the entire province. No firm data are available but judging by the trend in other provinces, the security situation has probably improved significantly, allowing 
uninhibited movement of goods and people. Many of the operational restrictions recently introduced by the central authorities and ruthlessly enforced in Kabul are unlikely in constrain programming in the province. Women-focused programming may he an exception though. The strong desire of the local authorities to work with aid agencies is suggestive of their awareness that, despite the change in the political balance. the development problems of the people of Ghor are not going to wither away. Given the likely continued absence of an effective national government for the foreseeable future, opportunities for a centrally led development initiatives are expected to remain limited. Under this circumstance, working at the local level with communitics is realistic and feasible, and this opportunity should be seized by the agencies that have participated in this survey. Afghanaid's cxperience clcarly shows that poverty is best tackled by creating an enabling environment, building local capacity and ensuring the participation of women in the development process. This approach is a major departure from relief and rehabilitation and provides opportunitics to build sucial capital, improve livelihood security and increase incomes to amclioratc rampant poverty. 


\section{REFERENCES}

Afghanaid-Monitoring and Research Unit (1998) A Baseline Survey Renort Chak, DaiMirdad and Kamdish Districts, Peshawar.

Afghanaid (1995) Rapid Rural Appraisal, Report on Basic Nc zis in Tulak, Shahrak and Chaghcharan Districts of Ghor Province, Peshawar.

Central Statistics Office (1975) A Provisional Gazetteer of Afghanistan, Volume Threc-B. Afghan Demographic Studics, Kabul.

Central Statistics Office (1996)_Estimated Population of Afghanistan, Kabul.

FAO (1997) Afghanistan Agricultural Strategy, TC: TCP/ AF(i/4552, Final Draft, FAO. Rome.

International Assistance Mission (1997) Report of the Survey Trip to Ghor Province, ('I)P. Herat.

Ludvig W., A. (1975) Heart and Northwestern Afghanistan, Historical and Political Gazetteer of Afghanistan, Akademische Druck-u. Verilagsanstalt, Graz, Austria.

The Swedish Committee for Afghanistan (1992) The Agricultural Survey of A fghanistan, Fourth Report.

The Swedish Committee for Afghanistan (1992) The Agricultural Survey of Afghanistan, Fifteenth Report, Part II, The Farming System in Najrab.

UNIDATA (1991) Population of Afghanistan, UNDP, Afghanistan Programme, Peshawar.

WFP (1997) Assessment Mission Report to Ghor, Herat. 
PRA Sample Villages 